\title{
Discourses of Security, Agricultural Innovation and Nature: the Cuban Transition to Agro-Ecology and the Construction of Campesino Identity
}

\author{
by \\ Lina Michelle Johnston \\ a thesis submitted to the Faculty of Graduate Studies and Postdoctoral Affairs \\ in partial fulfillment of the requirements of the degree of
}

Master of Arts

in

Anthropology

Carleton University

Ottawa, ON

(C) 2012

Lina Michelle Johnston 


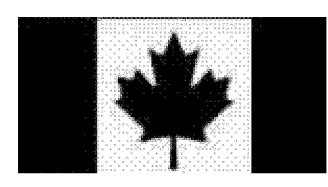

Library and Archives

Canada

Published Heritage

Branch

395 Wellington Street

Ottawa ON K1A ON4

Canada
Bibliothèque et

Archives Canada

Direction du

Patrimoine de l'édition

395 , rue Wellington

Ottawa ON K1A 0N4

Canada
Your file Votre référence

ISBN: 978-0-494-87778-4

Our file Notre référence

ISBN: 978-0-494-87778-4

\section{NOTICE:}

The author has granted a nonexclusive license allowing Library and Archives Canada to reproduce, publish, archive, preserve, conserve, communicate to the public by telecommunication or on the Internet, loan, distrbute and sell theses worldwide, for commercial or noncommercial purposes, in microform, paper, electronic and/or any other formats.

The author retains copyright ownership and moral rights in this thesis. Neither the thesis nor substantial extracts from it may be printed or otherwise reproduced without the author's permission.
AVIS:

L'auteur a accordé une licence non exclusive permettant à la Bibliothèque et Archives Canada de reproduire, publier, archiver, sauvegarder, conserver, transmettre au public par télécommunication ou par l'Internet, prêter, distribuer et vendre des thèses partout dans le monde, à des fins commerciales ou autres, sur support microforme, papier, électronique et/ou autres formats.

L'auteur conserve la propriété du droit d'auteur et des droits moraux qui protege cette thèse. $\mathrm{Ni}$ la thèse ni des extraits substantiels de celle-ci ne doivent être imprimés ou autrement reproduits sans son autorisation.
In compliance with the Canadian Privacy Act some supporting forms may have been removed from this thesis.

While these forms may be included in the document page count, their removal does not represent any loss of content from the thesis.
Conformément à la loi canadienne sur la protection de la vie privée, quelques formulaires secondaires ont été enlevés de cette thèse.

Bien que ces formulaires aient inclus dans la pagination, il n'y aura aucun contenu manquant. 


\begin{abstract}
This thesis explores the Cuban agro-ecological movement as it is interpreted and enacted by agricultural professionals (extension workers and scientists) and local farmers. It argues that the diverse ways in which these two groups of actors discursively and materially (in practice) define agro-ecology, exposes not only the reductionist nature of discourse but also highlights contradictions and subtle resistances to the agro-ecological movement. Notably, the deployment of state and professional supported discourses that are tied to agro-ecology, in some sense, eclipse farmer discourses that have also been engendered as a result of Cuba's transition to agroecology. Ultimately, the broader import of such discursive discrepancies and resistances is that they expose not only a chemical-dependency, but also profit-driven motivations among some Cuban farmers.
\end{abstract}

Keywords: agro-ecology, agro-chemical, farmer identity, discourse, power and resistance, political ecology, multiple scales of reference; space 


\section{Acknowledgements}

Primarily, I must express my sincere gratitude to the campesinos and agricultural extension workers who participated in this study, gave freely of their time, and welcomed me into their homes and offices. I am also truly thankful to Deborah Henderson for mentoring me throughout the process of coordinating research in Cuba. Deborah introduced me to the kind people at the University of Sancti Spiritus and CNSV-- without their involvement, this research would not have been possible. I also express great thanks to Jorge Luis Ayala Sifontes and Elba Maria Ferrer for acting as my translators, and for providing invaluable expertise. I am genuinely indebted to Alberto Matias Gonzalez for not only responding to each of my questions with kindness and patience, but also for his support and guidance. Without the encouragement, prompt advice, and constructive criticism of Claudio Aporta and Patricia Ballamingie, my supervisors, the final version of this thesis would not yet be completed. Also, thank you to Michael Mopas whose questions forced me to think about the greater import of this research. Finally, thank you to my family. 


\section{Table of Contents}

Abstract

Acknowledgements

ii.

Table of Contents

iii.

List of Acronyms

List of Tables and Figures

v.

vi.

Chapter 1: Introduction

Page 1

Chapter 2: Theoretical Considerations

Page 17

Chapter 3: Methodological Approach: Doing Research in Cuba

Page 25

Chapter 4: The Discourse of Food Security

Page 44

Chapter 5: Lived Dimensions of the Agro-Ecological Agenda

Page 58

Chapter 6: Ecology or Economy?

Page 73

Chapter 7: Conclusion

Page 90

Bibliography

Page 100

Appendix A: List of Participants

Page 105

Appendix B: Interview Guides

Page 107

Appendix C: Letters of Information and Consent Forms

Page 109

Appendix D: Translator Confidentiality Agreement

Page 115 


\section{List of Acronyms}

AAFC Agriculture and Agri-Food Canada

ACTAF Asociación Cubana de Técnicos Agricolas y Forestales (Cuban Association of Agricultural and Forestry Technicians)

ANAP Asociación Nacional de Agricultores Pequeños (National Association of Small Farmers)

CCS Cooperativa de Créditos y Servicios (Credit and Service Cooperative)

CDR Comités de Defensa de la Revolución (Committees for the Defense of the Revolution)

CITMA Ministerio de Ciencia, Tecnología y Medio Ambiente (Ministry of Science, Technology and Environment)

CMEA Council for Mutual Economic Assistance

CNSV Centro Nacional de Sanidad Vegetal (National Centre for Plant Protection)

CPA Cooperativa de Producción Agropecuaria (Agricultural Production Cooperative)

EEPF Estación Experimental de Pastos y Forrajes, Indio Hatuey (Indio Hatuey, Pasture and Forage Experiment Station)

FAO Food and Agricultural Organization

INISAV Instituto de Investigaciones de Sanidad Vegetal (National Plant Protection Institute)

MINAG Ministerio de Agricultura (Ministry of Agriculture)

UBPC Unidad Básica de Producción Cooperativa (Basic Units of Cooperative Production)

UNISS Universidad de Sancti Spiritus, José Martí Pérez (University of Sancti Spiritus, José Martí Pérez) 


\section{List of Tables and Figures}

Table 1.1: Select Agro-Industrial Policies of the Cuban Communist Party, $6^{\text {th }}$ Congress, April 2011

Table 1.2: Common Agro-ecological Practices

Page 13

Figure 3.1: In the Field

Page 34

Figure 4.1: Signage on the Road to INISAV, Banao Field Station

Page 45

Table 4.1: How Cuban Professionals define Food Security as Compared to FAO Definition

Page 48

Figure 5.1: Living Barrier-- floral trees (Promoter A)

Page 62

Figure 5.2: Living Barrier-- floral trees, other plants and shrubs (Promoter A) Page 62

Figure 5.3: Rice Field surrounded by a "Living Barrier" Dike (Promoter B)

Page 63

Figure 5.4: Pineapple Tree in "Living Barrier" Dike (Promoter B)

Page 63

Figure 5.5: Royal Palm tree trunks embedded in terrain to prevent erosion

Page 66

Figure 5.6: Grass Thoroughfare-- banana (left) and papaya (right) plantations

Page 66

Figure 5.7: "Monoculture" Corn Field—between grass (front) and palm trees (back)

Page 69

Figure 5.8: Banana Plants showing damage due to herbicide use

Page 70

Figure 5.9: Lemon tree leaves showing damage due to fungus (black residue on leaves)

Page 70

Figure 6.1: Martí Quotes Displayed at ANAP Headquarters

Page 78

Figure 6.2: Martí Quote Displayed on opposite side of

CCS Cooperative Sign (Banao)

Page 79

Figure 6.3: Martí Quote Displayed on Home in Cabaiguan

Page 79

Table 6.1: Economic Restraint that Dictates Campesino Use of Agro-ecological Practices 


\section{Chapter 1: Introduction: Cuba's Agro-ecological Movement}

\subsection{Introduction}

Stephen Palmié (2002: 261) casts the following prosaic image of the current state of Cuban agriculture:

Under the shadow of rotting agroindustrial machinery, cane stalks continue to sway in the breezes that once swept... ships across the Atlantic and returned cargoes of sugar, coffee, and tobacco.... Lack of gasoline and spare parts and adverse world market conditions have rendered these former sites of agroindustrial production mere sites of waste: of time, of human effort, of hopes invested in a socialist future.

Palmie's project revolves around grappling with questions of Cuban modernity, which is well beyond the scope of this thesis. However, the image of dilapidated farm machinery is relevant for two reasons. First, it embodies my original, romantic and rather misguided, intrigue with Cuban agro-ecology as a return to pre-modern, traditional forms of food production. Second, it foregrounds the enormous social and economic impact of post-Soviet conditions in Cuba. Prior to 1989 , Cuba had evolved a highly industrialized, chemical and mechanical-intensive agriculture, the functioning of which was dependent upon imports, such as oil from the Soviet Union. However, the dissolution of socialism, "first in eastern Europe in 1989 and then in the Soviet Union in 1990" resulted in a dramatic decrease of oil and other imports to Cuba (Oxfam, 2010: 6; Kapcia, 2008: 157). In order to cope with this crisis, known as the Special Period in Times of Peace, the Cuban government initiated a massive reformation of their agricultural system from chemical and mechanical, to sustainable ${ }^{1}$ and traditional means of producing food. These conditions of austerity and transformation not only quash my original romanticizing of

\footnotetext{
${ }^{1}$ For the most part, sustainable agriculture, also popularly known as organic agriculture, will be referred to as agroecology, or ecological agriculture throughout this thesis. Agro-ecology refers to applying the science of ecology to agriculture; as such, it takes into account the needs of ecosystems, and is situation and context-dependent. Although agro-ecology does not necessarily entail the complete eradication of chemical inputs in agriculture, it is positioned against the monocultural ideology of industrial agricultural that does not take into account individual ecosystem needs. Also, see Table 1.2: Common Agro-ecological Practices below.
} 
Cuba's return to traditional agricultural practices, like animal traction, but are also the basis of my continued interest in the Cuban agricultural system.

In this introduction, I proceed by first outlining the research questions and objectives that this thesis seeks to address in Section 1.2. Next, Section 1.3 details the historical and political issues that are relevant to this research, and that help to contextualize Cuba's transition to agroecology. Section 1.4 describes the particular agricultural institutions that were important gatekeepers for my research, such as the National Association of Small Farmers (ANAP) and the National Plant Protection Institute (CNSV). Globally, Cuba is generally perceived to be at the vanguard when it comes to practicing ecological agriculture, and rightly so. However, in order to provide a more locally nuanced representation of the Cuban agricultural system, Section 1.5 explains the current state of agro-ecology in Cuba, specifically in terms of the continued use of chemical inputs. Finally, Section 1.6 briefly points to my findings, and describes the chapter layout.

\subsection{Research Questions}

Based on ethnographic fieldwork conducted with two groups of study participants: agricultural extensions workers and scientists, and farmers ${ }^{2}$ in Sancti Spiritus, a province located in central Cuba, this research project explores the current socio-political impact of Cuba's ongoing agrarian reform. Primarily, this thesis examines the relationship between farmer-identity and how they interpret the shift to ecological agriculture, and define it both discursively and materially (in practice). In particular, I will look at what Premat (2009: 33) deems "government discourses" that, in part, revolve around promoting agro-ecological values and ideals among producers. In this sense, discourses of food security, agricultural innovation, and nature are

\footnotetext{
${ }^{2}$ For the sake of simplicity, throughout this thesis, agricultural extension workers, and scientists are referred to as professionals. Also, I use the terms farmer, producer and campesino (peasant farmer in Cuban terms) interchangeably.
} 
deployed as means to furthering the state's agro-ecological campaign. State supported slogans such as "Producir alimentos esencial para recuperarnos" (To produce food is essential for us [Cuba] to recover) and "Necessity is the mother of innovation" are both written on public spaces, and commonly subscribed to by agricultural scientists and extension workers. While integration of the agro-ecological movement ${ }^{3}$ is largely bound to state and professional interests and services, local mobilization and participation were, and continue to be, instrumental to Cuba's survival of the Special Period (Kapcia 2008: 174- 78). As such, slogans like "Campesino, siempre un paso mas" (Farmers, always one step ahead) figure into the quotidian lives of Cuban citizens, and attest to the central role that farmers, as local actors, play within agrarian reform initiatives.

Although the execution of state interests is dependent upon local participation, there exists a socio-cultural divergence between state and local intentions. ${ }^{4}$ For example, Weinreb (2009) exposes that on the local level, state-supported discourses are subject to social cooptation that is materially manifest in the daily lives of Cubans. In addition, Premat's work on urban agriculture in Havana (2005: 153) demonstrates not only a divergence between state and local perspectives, but also a plurality of viewpoints and practices that work to both support and subvert the long-term practice of urban (ecological) agriculture. Premat (2009: 1) has also argued that "the significant role played by a range of non-state actors, and interests, [are] largely left out from most scholarly accounts of Cuba's recent agricultural developments." Thus, following the

\footnotetext{
${ }^{3}$ Social movements are typically associated with the grassroots mobilization of a group of people who try together to achieve a common social or political goal. Indeed, Cuba's response to the collapse of socialism in 1989 relied to an extent upon local grassroots participation and mobilization. However, I use the term "movement" interchangeably with "agenda" and "campaign" to refer to the state-level processes and strategies geared toward developing agro-ecology, with the implicit understanding that the state and the local, and the actors therein, are not separate but are engaged in a network of interrelations.

${ }^{4}$ As I noted, this research is based on two study populations: agricultural professionals (extension workers and scientists) and producers. Evidently, both populations are local actors; however, in their professional capacity, the agricultural professionals in my sample generally seek to implement state interests with regards to agro-ecology. Inasmuch as they actively work to implement state interests, then, professionals are "extensions" of the state.
} 
trajectories of Weinreb and Premat, this research poses the following questions: 1) how are statesupported discourses locally interpreted, and internalized in processes of identity construction and self-representation? 2) How are processes of discursive construction and identity formation materially manifest in agricultural practice, and farm-spaces? 3) How does state and popular promotion of notions of nature, in terms of building agro-ecological values, impact farmer preferences for using ecological or chemical practices? 4) How does the relationship between agricultural professionals and producers embody both the acceptance and subversion of the agroecological agenda? Clearly, professionals and producers interpret and enact the agro-ecological movement in diverse ways; however, the reductionist nature of dominant discourse is laid bare by exploring this diversity, which, in turn, gives rise to contradictions and resistances to the agroecological movement.

\subsection{Historical Context: 1989 to Today}

During Cuba's early Revolutionary period, ${ }^{5}$ ideas of modernity and progress certainly permeated the agricultural sector: "The blue print [for which]... came from the global strategy of the industrialized countries, including the Socialist Bloc in Eastern Europe" (Funes et al. 2002: 5).

For instance, after the Revolution,

Cuba rapidly evolved a sophisticated network of crop and animal research institutes controlled by the Ministry of Agriculture, several research stations run by the Ministry of Higher Education, and the research facilities of the Ministry of Sugar Production....Very quickly Cuba's research enterprise moved Cuba into a high-input [mechanical and chemical], high-yield producer of its traditional crops, especially sugar (Rosset and Benjamin 1994: 74). ${ }^{6}$

Through 1972 to 1989, the functioning of Cuba's industrialized agriculture relied upon close trade relations with the Soviet Union, the breakdown of which has had sustained consequences:

\footnotetext{
${ }^{5}$ The Cuban Revolution triumphed over Fulgencio Batista's dictatorship in 1959.

${ }^{6}$ Without providing a history of the development of modernity, suffice to say that it is, in part, characterized by notions of progress, efficiency and industrial machinery and mechanisms, all of which contribute to notions of highinput and highly productive industrial agriculture.
} 
CMEA [Council for Mutual Economic Assistance] ${ }^{7}$ imports plummeted by over a half in two years, affecting everything in an economy that, since 1972, had relied on CMEA manufactures and oil; indeed, Soviet oil deliveries collapsed by some 85 per cent between 1989 and $1992 \ldots$. In 1990-94, the whole economy fell by around 38 per cent and ran at an estimated 60 per cent of its capacity at best (Kapcia 2008: 157).

In order to address import shortages, and ultimately the forced transformation of their agricultural system, the Cuban state introduced a number of measures ${ }^{8}$ that revolved around, first providing greater production incentives for farmers by creating new models of farming cooperatives; and second, dealing with the new situation that required "low external input... while boosting production," ecological and economic sustainability, and self-sufficiency (Oxfam 2010; Funes et al. 2002: 7).

The implementation of such measures, moreover, compelled a number of strategies, one of which is pertinent to this project: "the challenge of creating a comprehensive and scientifically sophisticated knowledge base to support the new [low-input] model" (Rosset and Benjamin1994: 66- 7). The development of a scientifically sound knowledge base entailed a shift in the type of research that was being conducted in Cuba, and that had been characterized by Revolutionary ideals of modernity and progress. Rosset and Benjamin (1994: 74- 5) point out that a minority of Cuban scientists began to voice concern regarding the environmentally destructive consequences of high-input agriculture; however, it was only after the collapse of such agriculture that "these scientists found themselves at the top of political and administrative agendas." This group of scientists was "motivated by concerns over the fate of nature"; thus, the new direction in

\footnotetext{
${ }^{7}$ The Council for Mutual Economic Assistance was a trading network formed by the Soviet Union in 1949 with the purpose of coordinating economic cooperation between the Soviet Union and member countries. Cuba became a member country in 1972 (Kapcia 2008: 37).

${ }^{8}$ The measures were as follows: decentralization of the state farm sector through new organizational forms and production structures; land distribution to encourage production of different crops in various regions of the country; reduction of specialization in agricultural production; production of biological pest controls and biofertilizers; renewed use of animal traction; promotion of urban, family, and community gardening movements; opening of farmers markets under 'supply and demand' conditions (Funes et al. 2002: 7).
} 
scientific research was primarily centered on tapping into what nature could provide: ecological and biological, rather than chemical pest controls and fertilizers (Ibid.). An additional significant factor in the change of research focus was the Cuban government's emphasis upon local farmer knowledge and participation. Scientists continue to rely on this knowledge for not only the recovery of traditional technologies, but also the development of such technologies at the local level (Rosset and Benjamin 1994: 77; Funes et al. 2002). Farmers that are innovative and able to combine scientific knowledge with their own experiential and traditional knowledge are valued as assets that further the agro-ecological agenda. Knowledge exchange between campesinos, and professionals is not seamless, though, but is constituted by complex power dynamics. Given these dynamics, this thesis examines the extent to which farmer knowledge and innovations are considered valuable, and integrated into the agro-ecological paradigm. Moreover, in order to capture the local experience of Special Period agrarian policy, and the potential tensions between the state and the local, this research has involved interviews and participant observation with both producers, and agricultural extension workers and scientists that work within the new research paradigm of agro-ecology.

Notably, not everyone agrees that agro-ecological farming in Cuba is a consequence of the 1989 crisis. Levins (2005: 7), for instance, maintains that Cuba's commitment to agroecology and ecological development is not "an improvised emergency response to the Special Period.... Rather, it has its roots in a complex history of colonial science, anti-imperialism, the emergence of a self-conscious community of ecologists, and the transformations of Cuban society since 1959." In her discussion of urban agriculture in Havana, and more specifically of the dissonance between state and local discourses, Premat (2005: 171) also observes that most local producers "commented on the continuity of the practice [of urban agriculture], tracing it to 
familial or neighbourhood precedents from before the 1989 crisis." Despite debate around the origin of agro-ecology, the paradigm shift is important in that it demonstrates how, as a result of certain processes like the Special Period, certain ideas, knowledges, and values become predominant, or hegemonic. In this way, the continued education and training of farmers, and Cuban citizens, in part, revolves around developing agro-ecological values, such as tapping into nature for ecological and biological pest controls and fertilizers, and subscribing to an ecological consciousness. As such, this thesis also reflects upon the extent to which state and professional endorsement of agro-ecological values influences farmer identity and agricultural practice.

A further concern that is bound to Cuba's evolving agricultural system is that of food security. To be sure, addressing food insecurity was an imperative of the Revolution; yet, as Funes et al. (2002: 44) point out: "Despite progress in Cuban agriculture between the 1960s and 1980s, food sufficiency and diversity to meet the population's basic needs was never achieved. Thus at the end of the 1980s, Cuba imported approximately 50 percent of the food needed to cover the basic requirements of humans and livestock." Given that imports plummeted with the fall of the Soviet Union, it is hardly surprising that food shortage was acute during the early years of the Special Period. During this time, "Daily per-capita caloric intake fell from 2,908 in 1989 to 1,863 calories in 1995 , according to the USDA, and protein intake dropped by $40 \%$. Some estimated that the average Cuban lost 20 pounds by 1994" (Oxfam 2010). Notwithstanding some measure of economic recovery, and increasing food availability, food shortage continues to be a chronic concern of the Cuban nation. Notably, by 2002 caloric intake by average Cubans had not reached global recommendations for consumption (Funes et al. 2002: 48). Moreover, Agriculture and Agri-Food Canada (AAFC) 2009 statistics cite that Cuba "imports 
approximately $80-85 \%$ of its foodstuff requirements" (AAFC 2009). ${ }^{9}$

In recent years, strategies to augment food security have run parallel to agrarian policies that seek to reduce imports; the latest of such policies were decided upon during the $6^{\text {th }}$ Congress of the Communist Party of Cuba in 2011, and outlined in a document popularly known as los lineamentos (the guidelines) (see Table 1.1: Select Agro-Industrial Policies of the Cuban Communist Party, $6^{\text {th }}$ Congress, April 2011). Similar to the focus of Special Period agrarian reforms, agro-industrial programs currently aimed at reducing imports prioritize the production of particular crops using low-input, high yield, ecologically and economically sustainable agriculture. One of these programs is commonly known as cultivos potenciados con paquetes tecnologicos (enhanced, or prioritized, crops with technological packages). Indeed, during my fieldwork (May to June 2011) this program garnered much discussion among producers and professionals, and is delineated in lineamento (guideline) 193 as follows: "Ensure fulfillment of the programs for the production of rice, beans, corn, soy and other grains and pulses to guarantee increased production, in order to contribute to a gradual reduction in imports of these products" (Communist Party of Cuba 2011). Campesinos who produce these "enhanced" crops receive state-administered packages of agricultural inputs (that include chemical fertilizers and pesticides) geared to ensure successful production. However, it is within this system of state control of resources that producer resistance to the agro-ecological movement can be appreciated, albeit subtly. In terms of this historical context, then, two key foci of this research project revolve around how state-level processes impact and shape producer discourses; and how these processes are rolled into the broader agenda of agro-ecological development.

\footnotetext{
${ }^{9}$ Although the AAFC does not provide a breakdown regarding which countries Cuba imports foodstuff requirements from, they note: "Cuba does regular trade with over 80 countries worldwide.... Their largest import sources in 2007 were Venezuela (29.6\%), China (13.4\%), Spain (10.4\%), and Canada (6\%). Although the United States is not listed as one of their top import sources, $96 \%$ of exports from the US to Cuba are agricultural products" (AAFC 2009).
} 
Table 1.1: Select Agro-Industrial Policies of the Cuban Communist Party, $6^{\text {th }}$ Congress, April 2011 ${ }^{10}$

\begin{tabular}{|c|l|}
\hline $\begin{array}{c}\text { Lineamento } \\
\text { (guideline) }\end{array}$ & \multicolumn{1}{c|}{ Policy } \\
\hline 184 & $\begin{array}{l}\text { Prioritise, in the short term, the substitution of imports of food that can be } \\
\text { produced efficiently in Cuba. The necessary resources must be concentrated } \\
\text { where they can be used most effectively with the aim of boosting yields and } \\
\text { productive efficiency while promoting the application of scientific and technical } \\
\text { advances. }\end{array}$ \\
\hline 185 & $\begin{array}{l}\text { Organise agricultural production around activities that earn export incomes or that } \\
\text { substitute imports, with a systematic approach to the productive chain that } \\
\text { considers not only primary production but all the links in the agro-industrial } \\
\text { complex. These productive chains should be developed using the sector's internal } \\
\text { resources, on the basis of net incomes via exports or of savings via import } \\
\text { substitution. In the organisation of other productive activities a regional and local } \\
\text { approach must predominate, directed towards local self-sufficiency with an } \\
\text { emphasis on the execution of the program to develop agricultural "green belts" on } \\
\text { the urban fringes. This program should be extended to the whole country. }\end{array}$ \\
\hline 190 & $\begin{array}{l}\text { Maintain the regulatory role of the state in the setting of farm gate prices of } \\
\text { agricultural products that substitute imports, or that generate export revenues, to } \\
\text { create an incentive for primary producers. Price fluctuations on the international } \\
\text { market will be taken into account. }\end{array}$ \\
\hline 193 & $\begin{array}{l}\text { Ensure fulfillment of the programs for the production of rice, beans, corn, soy and } \\
\text { other grains and pulses to guarantee increased production, in order to contribute } \\
\text { to a gradual reduction in imports of these products. }\end{array}$ \\
\hline 206 & $\begin{array}{l}\text { Carry out the urban fringe "green belts" program by making efficient use of the } \\
\text { farmlands that surround cities and towns, based on minimal use of fossil fuels and } \\
\text { imported inputs, local resources and the widespread use of animal traction. }\end{array}$ \\
\hline
\end{tabular}

\subsection{Cuban Agricultural Institutions}

In broad terms, food is produced in Cuba through state enterprises and non-state entities; this research was conducted solely with non-state farmers, and so this discussion is limited to the non-state sector. Much of the non-state sector is characterized by collective, or cooperative, farming. For example, private farmers that are not associated with cooperatives account for $1 \%$,

\footnotetext{
${ }^{10}$ Document sources:

Cuba's Socialist Renewal. 2011. Translation: Guidelines debate 18, Agriculture. October 23, 2011.

<http://cubasocialistrenewal.blogspot.com/search?q=part+18>

Lineamentos de la política, económica, y social del partido y la revolución. VI Congreso del partido comunista de Cuba. April 18, 2011. Pp. 27-9.
} 
66, 100 hectares, of productive land in Cuba, while those associated with cooperatives account for 22\%, 1.5 million hectares (Oxfam 2010; Funes et al. 2002: 73). There are three types of nonstate cooperatives: Agricultural Production Cooperatives (CPA), Basic Units of Cooperative Production (UBPC), and Credit and Service Cooperatives (CCS). According to Funes et al. (2002: 61), "The CPAs are the traditional revolutionary form of cooperative production in Cuba, founded in 1977 by farmers who voluntarily choose [sic] to unite their private individual lands and resources for increased production, marketing, and economic efficiency." UBPCs were formed in the early 1990s in a process of "de-statization of state property and infrastructure" (Ibid.). CCSs are based on the family farm model, and are made up of individuals that have private ownership of their farms (Funes et al. 2002: 63). The process through which individual farmers began to conglomerate into CCSs is somewhat fluid and difficult to track. Maria Gropas (2006: 257) asserts, however, that from 1975 onwards, cooperativisation began with the CCS structure. The research for this thesis is based on a sample of $12 \mathrm{CCS}$ farmers ${ }^{11}$ from the province of Sancti Spiritus; thus, it is important to briefly explain how this particular cooperative structure functions: CCS farmers

... work their farms independently, but join together to receive credit and services from state agencies. They may also share certain machinery and equipment.... CCS members purchase inputs and sell products at fixed prices through state agencies, based on production plans and contracts established with state distribution systems. Any production above and beyond the contracted quantity may be sold in the farmer's markets at free market prices (Funes et al. 2002: 63- 4).

Thus, although CCS campesinos are technically private, the state contractual system, to an extent, delineates the type and quota of crops they produce. Furthermore, similar to the cultivos

\footnotetext{
${ }^{11}$ The sample of producer-participants that I worked with was selected by the gatekeepers of this research project (methodological considerations are dealt with in Chapter 3). In contrast to CCS farmers, CPA and UBPC farmers are perceived to be more influenced by the Cuban government because they do not own their land privately. Thus, the rationale in selecting solely CCS farmers was based on the notion that because they own their land, they have more control, and are less influenced by the government. Hence, "if you want to know the way of thinking of farmers in Cuba, you should go to visit them [CCS farmers]" (CNSV employee, email correspondence, 2011).
} 
potenciados con paquetes tecnologicos (enhanced crops with technological packages), as part of the contract system, the state administers the agricultural inputs (in packages that include chemical fertilizers and pesticides) deemed necessary to produce contracted crops. ${ }^{12}$

Additionally, CPAs and CCSs belong to a non-governmental organization called the National Association of Small Farmers (ANAP), which has been in operation since 1961. As one producer explained: "ANAP is like a trade union-- they lead you and provide information" (Producer 7, interview, 2011). In this way, ANAP gives "organizational and productive support, as well as training, promotion, marketing, international cooperation, for small farmers" (Funes et al. 2002: 8- 9). Similar to ANAP, The National Centre for Plant Protection (CNSV) provides agricultural extension services whose representatives work in close contact with campesinos. However, CNSV is a governmental organization and has been described to me as an "arm" of the Cuban Ministry of Agriculture (MINAG). CNSV is responsible for the production and distribution of biological controls, and the monitoring of chemical and biological input use across farms. ${ }^{13}$ Producers can contract with CNSV for their services: if a producer suspects they have a pest or disease, they take a sample to CNSV, which then administers the proper treatment, either chemical or biological, depending on the situation, and preference of the producer. If the recommendations are not followed, producers can be penalized (CNSV employee, conversation, 2011). ${ }^{14}$ ANAP and CNSV are two among many agricultural institutions in Cuba that promote

\footnotetext{
${ }^{12}$ For example, the campesinos in my sample typically produce tobacco or onion. These crops are important to the Cuban economy, and can draw a large profit for producers. Hence, the contracts to produce these crops benefit both the state and producers.

${ }^{13}$ Please note that CNSV is the national-level organization; under this organization, there is The National Plant Protection Institute (INISAV), which is the scientific branch, as well as the provincial-level offices [Direcciones de protección fitosanitarias provinciales (Directions of Provincial Plant Protection)]. Under this provincial-level organization, there are various plant protection stations, and the extension workers from these stations were involved in this research project. As such, I use the abbreviation CNSV throughout this thesis for the sake of simplicity. during my fieldwork (May- June 2011), CNSV was being re-structured, and their responsibility in the production side of biological controls was being phased out.

${ }^{14}$ It was not entirely clear what kind of penalties farmers can face if they do not follow CNSV recommendations.
} 
ecological agriculture; in particular, though, these organizations, and their employees, served as both key gatekeepers and informants of this research project.

\subsection{The Status of Cuba's Agro-Ecological Development}

Traversing the Special Period agrarian reforms, the implementation of ecological agriculture, and the current focus on import reduction and augmenting food security are the Cuban government's emphases on low-input, high yield agriculture that is both ecologically and economically sustainable, and that fosters self-sufficiency. Indeed, such emphases have evolved into a diffuse organic farming movement, whereby 70 to 80 percent of food in Cuba is presently produced agro-ecologically (Morgan 2006; Ayala, conversation, 2011). Transitioning to ecological agriculture has thus far entailed what Funes et al. (2002: 16) refer to as "input substitution," which is essentially geared toward replacing chemical and mechanical inputs with those that are more ecologically and economically sustainable. Generally, advancements have been made in the areas of organic fertilization and soil conservation; ecological management of pests, diseases and weeds; crop management; and ecological soil management (Funes et al. 2002: 16- 18). Each of these areas accord with a wide gamut of practices; Table 1.2 below outlines the specific practices that I observed among the $12 \mathrm{CCS}$ farms in my sample, and that are referenced throughout this thesis. Although "input substitution" is widespread across urban, peri-urban and rural agriculture, it is within urban farming that agro-ecology has had the greatest integration. Funes et al. (2002: 18) partially attribute this success, though, "to the prohibition of the use of chemicals because of the proximity to dense human populations." Here, Funes et al. point to two considerations that are central to this project: first, chemical inputs are highly controlled and distributed by the state according to not only region, but also type of crop being produced; and second, the use of chemical inputs remains a common practice among rural campesinos. 
Table 1.2: Common Agro-ecological Practices ${ }^{15}$

\begin{tabular}{|c|c|c|}
\hline Purpose & Practices & Description \\
\hline \multirow{4}{*}{$\begin{array}{l}\text { Organic } \\
\text { fertilization } \\
\text { and soil } \\
\text { conservation }\end{array}$} & Vermicompost & $\begin{array}{l}\text { Vermicompost is created through vermiculture-- the raising of earth } \\
\text { worms in order to use their by-products (castings) as compost. The by- } \\
\text { products are used as fertilizer. }\end{array}$ \\
\hline & Organic compost & $\begin{array}{l}\text { A mix of various decaying organic substances, such as dead leaves and } \\
\text { manure, to be used as fertilizer. In Cuba, a common practice is to leave } \\
\text { harvest residuals (what is left of plants once the crop has been harvested) } \\
\text { in the fields to later be ploughed into the soil. }\end{array}$ \\
\hline & Biodigester & $\begin{array}{l}\text { A tank within which pig manure is fermented: the gases are used as } \\
\text { biogas to fuel kitchen appliances; and the liquid and solid residues are } \\
\text { used as fertilizer. }\end{array}$ \\
\hline & $\begin{array}{l}\text { Effective } \\
\text { Microorganisms }\end{array}$ & $\begin{array}{l}\text { Entails fermenting a mixture of starch, lactobacillus, sugar, and organic } \\
\text { compost. The mixture is diluted with water, and can be sprayed in crops } \\
\text { and gardens as a source of fertilizer. Referred to in Cuba as "efficient } \\
\text { microorganisms." }\end{array}$ \\
\hline \multirow[t]{2}{*}{$\begin{array}{l}\text { Ecological } \\
\text { management } \\
\text { of pests, } \\
\text { diseases and } \\
\text { weeds }\end{array}$} & $\begin{array}{l}\text { Biological } \\
\text { controls }\end{array}$ & $\begin{array}{l}\text { There are a range of biological controls that either 1) exist in nature, or } \\
\text { 2) are produced using biological organisms. 1) Examples include: living } \\
\text { barriers and intercrops (see below). 2) Examples include trichoderma-- a } \\
\text { microbial bio-pesticide used to control soil-borne pathogens, and } \\
\text { trichogramma-- a type of beneficial insect that infects the eggs of a } \\
\text { variety of insect pests with parasites. }\end{array}$ \\
\hline & $\begin{array}{l}\text { Integrated Pest } \\
\text { Management } \\
\text { (IPM) }\end{array}$ & $\begin{array}{l}\text { An approach to pest management that combines understanding the } \\
\text { causes of pest outbreaks, manipulating the crop ecosystem for pest } \\
\text { control, and monitoring pest populations and their life cycles to } \\
\text { determine if and when the use of pesticides is indicated. }\end{array}$ \\
\hline \multirow[t]{2}{*}{$\begin{array}{l}\text { Crop } \\
\text { management }\end{array}$} & $\begin{array}{l}\text { Intercropping } \\
\text { (polyculture) }\end{array}$ & $\begin{array}{l}\text { Intercropping refers to producing two or more crops in the same area, } \\
\text { during the same year. Crops are typically sown consecutively or in } \\
\text { association (Funes et al. 2002: 145). }\end{array}$ \\
\hline & Crop rotation & $\begin{array}{l}\text { The rotation of different crops on the same plot of land, or between } \\
\text { different plots of land. Rotation helps to reduce pest infestation, but also } \\
\text { allows the land to rest and replenish during fallow periods. }\end{array}$ \\
\hline \multirow[t]{2}{*}{$\begin{array}{l}\text { Ecological } \\
\text { soil } \\
\text { management }\end{array}$} & Contour plowing & $\begin{array}{l}\text { Plowing against the slope of the terrain to prevent from rapid running } \\
\text { water (rain or irrigation), which creates erosion. This practice is } \\
\text { important because many farmers irrigate by gravity, which also supports } \\
\text { sustainability. }\end{array}$ \\
\hline & Living barriers & $\begin{array}{l}\text { A crop that is introduced into an agro-ecosystem to manage pest and } \\
\text { disease infestation: "One crop can function as a physical barrier to pest } \\
\text { movement between the rows of another crop, and/or insect pests can be } \\
\text { confused by the odors and colors of the different crops. Thus, the rate of } \\
\text { pest invasion, dissemination, and reproduction can be lower in } \\
\text { polyculture systems than in monocultures. One crop can also provide a } \\
\text { habitat or refuge, and/or supplemental food source such as nectar, } \\
\text { attracting beneficial insects that may be natural enemies of the pests of } \\
\text { another crop in the same system" (Ibid.). }\end{array}$ \\
\hline
\end{tabular}

\footnotetext{
${ }^{15}$ The practices defined in this table are not representative of the full range of agro-ecological practices available, but are limited to those that I observed during fieldwork.
} 
As illustrated through the cultivos potenciados con paquetes tecnologicos (enhanced crops with technological packages) and state contractual system discussed above, chemical use is not entirely prohibited by the state. However, there is an emphasis on the rational, or minimal, use of chemicals. Furthermore, although I do not delve directly into this practice given its complex nature, the purchasing of chemical inputs on the black market by rural campesinos is commonplace.

Within this context of continued chemical use, what further complicates the shift to agroecology are popular beliefs and preconceptions that are tied to a deeply embedded tradition of industrial agriculture originating with Revolutionary agrarian reforms. Notably, some producers are both covertly and overtly resistant to adopting sustainable technologies that derive from the transition to ecological agriculture (Couret 2001: 4, 6). In response to this resistance, Funes et al. (2002: 24) assert:

[W]e must not lose the commitment and dynamic of work among people who are conscious of the importance of this paradigmatic shift in agriculture, especially with the threat that the new paradigm will face when imported chemical inputs become widely available again, given that there still are many farmers who use organic methods out of necessity rather than conviction.

The notion of adopting agro-ecology out of necessity amounts to the preconception that ecological agriculture evolved as a temporary solution to the austere conditions of the 1989 crisis. Couret (2001: 3), in her discussion of Cuban ecological theory and practice, argues that understanding sustainable development as only a temporary means to survival simultaneously casts it as an ad hoc model of development. Phinney (2003) further suggests that ecological agriculture, as a forced survival response, has been construed as a practice for the povertystricken. Ultimately, such resistances and preconceptions foreground what is often obscured by the fact that Cuban agro-ecology is lauded as a success: the cultural impact and social trauma 
that has accompanied the agricultural transformation.

Given the perceived fragility of the agro-ecological movement, it is significant that Cuba has experienced some measure of economic recovery, which is viewed as an impetus for some producers to return to industrial agriculture. Premat (2005:155) states, for instance, that "By 1997, Havana had 26, 600 officially registered urban agriculture plots geared toward family self provisioning... but by 2000 this number had dropped to $7944 . "{ }^{16}$ She goes onto note that Cuban experts "considered this decrease primarily a reflection of the country's economic recovery and the shift by some successful farmers to large-scale commercially oriented forms of agricultural production" (Ibid.). Cruz and Medina $(2003: 8,10)$ also observe that the current improved state of the Cuban economy has led producers to consider returning to the industrial technologies and practices used prior to the Special Period. In describing Cuba's strategic efforts to implement full-scale ecological agriculture, thus, my research aims to position the views, discourses and practices of rural CCS campesinos, some that have fully adopted agro-ecology, and others that have retained varying degrees of dependency on chemical inputs, within the current juncture of social resistance and growing economic stability in Cuba.

\subsection{Thesis Organization}

Chapter 2 of this thesis outlines the theoretical considerations that position the research questions and objectives delineated above. Chapter 3 discusses the methodological approach, ethical considerations and logistical complexities within which this project unfolded. Given that there are an extensive number of agricultural institutions in Cuba, and that Cuban bureaucracy, in certain instances, functions in a top-down fashion, I have had to negotiate several gatekeepers in

\footnotetext{
${ }^{16}$ It is important to note that certain agricultural professionals in my sample called this statistic into question. For instance, Paula Palenzuela Palenzueala [President, Cuban Association of Agricultural and Forestry Technicians (ACTAF)] offered the possibility that the number of urban agriculture plots had decreased due to the amalgamation of two or three smaller production sites to become one larger site.
} 
order to gain access to Cuban campesinos. In Chapters 4, 5 and 6 I present my findings. Briefly, Chapter 4 explores the professional discourse of food security as it is used and understood by producers; the discrepancy between how professionals and producers consider food security provides insight into the chemical-dependency of some campesinos. Chapter 5 examines the way in which professional discourses that revolve around ideal types of producers are both supported and subverted in the practices, and farm-spaces of campesinos. Chapter 6 examines statesupported discourses that center on reverence for nature, localization as a process that apparently fosters closer ties with nature, and ecological consciousness; this chapter questions how these discourses legitimate the transition to agro-ecology by contrasting them with campesino concerns that revolve around economic sustainability. Each of the results chapters function to: first, foreground the relationship between professionals and producers as critical in the transition to agro-ecology; and second, expose the extent to which discursive and material contradictions between these two groups of actors complicate the blanket term "agro-ecology." Finally, Chapter 7 concludes the thesis by integrating the concepts and findings discussed in order to point to broader implications; this chapter also delineates the limitations of the study, and future lines of inquiry. 


\section{Chapter 2: Theoretical Considerations}

\subsection{Introduction}

Theoretically, this research is grounded within a political ecological framework that seeks to understand how multiple scales of experience impact different actors, and the discourses they subscribe to. Given that political ecology is a broad conceptual framework with a number of potential implications ${ }^{17}$ in the analysis of how politics impact environment, Section 2.1 proceeds by first explicating the particular tenets of political ecology that relate to this thesis. Next, Section 2.2 explores social nature, a poststructuralist paradigm that develops a political ecological position. Social nature helps to theorize how the social construction of concepts like nature foregrounds power relations, and are interpreted and enacted at the local level. Finally, in order to further theorize the expression of power between professionals and producers, Section 2.3 draws on two theorists: Michel Foucault and Henri Lefebvre. Both Foucault and Lefebvre interpret power as expressed in multiple forms, one of which is from the bottom-up; while Foucault addresses the relation between discourse and power, Lefebvre's thinking around the production of space, and the power implications of that production, is useful in reckoning nondiscursive expressions of resistance.

\subsection{Political Ecology and Social Nature}

Broadly, political ecology examines the multiple interfaces between humans, culture and environment in terms of the larger economic, social, political and technological processes that

\footnotetext{
${ }^{17}$ There are a number of articles that trace the beginnings of political ecology as taking a political economy approach and applying it to environmental concerns. Gezon and Paulson (2005b: 17) explain, for example, that "analyses of social relations of production and questions of access and control over resources - the basic tool kit of political economy - are applied in order to understand forms of environmental disturbance and degradation and to develop prospects and models for environmental rehabilitation and conservation, as well as environmentally sustainable alternatives" (see also Gezon and Paulson 2005a, and Paulson et al. 2003).
} 
inform those interfaces. For the purposes of this research, political ecology can be thought of as a theoretical approach that starts with the local and "scales up to wider relations of power and difference" (Paulson et al. 2003: 213). Thus, this approach often consists of what is known as multi-scalar research; that is, looking at the different levels of social and political formation, such as the local, municipal, regional, and global and identifying how these different levels intersect and inform one another. Certainly, a focal point of this research revolves around how the Cuban state's implementation of ecological agriculture shapes the discourses and practices of two groups of study participants, agricultural professionals and producers. The explicit, yet inextricably linked, scales of the state and the local are important points of reference for this research. Although both professionals and producers are local actors, their identities are defined and produced by different socio-cultural "axes," such as formal agricultural education, vocation and family background (Premat 2005: 157; see footnote 1). In this way, their interpretation of the agro-ecological movement, and their relationship to the state in terms of this movement, also differs. ${ }^{18}$ Professionals further the state agenda of implementing ecological agriculture; they do this by providing education, and working with producers to adapt their practices to fit those promoted by ecological agriculture (such as employing polyculture versus monoculture). Producers, clearly, participate in this implementation; however, given that they both operationalize, and at times contest the agro-ecological agenda, it is my contention that producers experience and concretely live it in distinct ways. ${ }^{19}$ Significantly, political ecology

\footnotetext{
${ }^{18}$ In addition to "socially or culturally constructed and maintained axes of identity, such as those associated with..." formal agricultural education, vocation and family background, identity in the context of this research refers to that which is both externally and individually constructed (Premat 2005: 157). In this way, "farmer-hood" is constituted in diverse and overlapping ways by both professionals (external), and farmers (individual), and is tied to such things as agricultural practices employed, knowledge, skills and performance.

${ }^{19}$ It is important to note that my intent here is not to essentialize professionals and producers as entirely distinct and defined groups; certainly, actors assume different roles and positions in different contexts. However, for the purposes of examining the relationship between professionals and producers, the state and the local, it is important to explicate the nuanced ways in which these groups of actors experience the agro-ecological agenda.
} 
recognizes "a plurality of positions, perceptions, interests, and rationalities in relation to the environment" (Gezon and Paulson, 2005: 2). Understanding to what extent the agro-ecological movement, and the discourses invoked by its various actors are reflected in a "plurality of positions," and lived at the local level is the starting point of this research project.

The concept of social nature corresponds to political ecology in that it provides a framework for understanding how multiple actors interpret and deploy discourses of nature. Castree and Braun (2001) argue that embedded within the contested terrain of "nature" are ideologies and discourses, or "knowledges of nature," as Castree (2005: 13) terms them. He contends that "knowledges of nature (even scientific ones) frequently express social power relations and... these knowledges have material effects, insofar as people may believe and act according to them" (Ibid.). Discourses of nature are enmeshed within Cuba's agro-ecological movement wherein reverence for nature and ecological consciousness are seen as contributing to the relatively successful transition to agro-ecology. Certain theorists, like Stricker (2007: 118), argue that socialism has fostered such reverence, which is expressed in terms of not only cooperation between humans, but also between humans and nature:

...an essential lesson from socialist thought and the socialist experience... contributes to the understanding of sustainable development, that is, to organize society around the development of the whole person within the limits of nature as opposed to economically developing the society through the creation of false [commercial] needs in people.

Stricker uses the human-nature relation to explicate the divergence between neo-liberalism, linked to conspicuous consumption and prioritization of the individual, and socialism. In line with Stricker's views, Levins argues (2005: 8) that "each kind of society develops its own relations with the rest of nature, and that an ecological pathway of development is at least latent in socialist development, co-equal with equity and participation." Levins (2005: 21 8) also asserts that in the early years of the Special Period, "environmental conditions worsened while 
environmental consciousness deepened," and even argues that the failure of the Soviet Union can be attributed to their refusal to adopt an ecological pathway. Rosset and Benjamin (1994: 75) also point to "philosophical views about the environment" regarding the "immorality" of the potential harm to future generations, as well as the destruction of nature through industrialized agriculture; however, they do not follow Stricker's or Levins' trajectories in attributing humannature interdependence to socialist dogma. Thus, taking the idea that Cuban socialism somehow necessitates ecological consciousness into consideration, this research examines producer preferences for adopting agro-ecological or agro-chemical practices.

Indeed, material and economic limitations figure profoundly in the transition to agroecology, wherein access to resources is a contested terrain. On one hand, state control of agricultural inputs restricts the use of chemicals, and, thus, supports agro-ecology. However, on the other hand, campesino resistance to such strict state control can have a countervailing effect. In this regard, the purpose in examining multiple scales of reference also functions to expose how "social relations of production and questions of access and control over resources" have an environmental impact (Gezon and Paulson 2005: 17).

\subsection{Discourse and Lived Resistance}

In order to better conceptualize the complex and shifting ways in which the state and the local, professionals and producers intersect, I draw on Michel Foucault's work on discourse and power. For Foucault, discourse "operates to limit what can be said, what can become objects of our knowledge, and what is accepted as knowledge. That is, although material objects and social practices exist outside language, they are only 'brought into view' by language (Foucault in Waitt 2005: 170). In this way, Foucault "enables us to understand how what is said fits into a network that has its own history and conditions of existence (Barrett 1991: 126). Particular 
knowledges and discourses are not merely absolute; however, there is a process by which they become hegemonic, and thereby are perceived as absolute. Explicating the historical context within which knowledges and discourses become hegemonic, then, functions to not only call into question (destabilize) the hegemony, but also illuminates the existence of other non-hegemonic, and at times counter-hegemonic, knowledges and discourses. ${ }^{20}$ Moreover, the destabilizing effect of discourse analysis is an avenue to better understanding how state-supported discourses of food security, agricultural innovation, and nature are reflected and refracted in the local discourses of professionals and producers.

Foucault maintains (1984: 254): "What is interesting is always interconnection, not the primacy of this over that, which never has any meaning." Foucault seeks to unveil what might be construed as contextual networks within which particular discourses appear rather than others. Embedded within contextual networks, moreover, are relations of power. It is fitting, then, that "Foucault uses the notion of the capillary to describe the operations of power at a micro-level" (Barrett 1991: 135). For Foucault, power is "something that is exercised rather than possessed; it is not attached to agents and interests but is incorporated in numerous practices. Power can thus work from the "bottom up"" (amongst other directions) (Ibid.). This research addresses the exercise of power, particularly in terms of the relationship between agricultural professionals, who are, in a sense, extensions of state-power, and producers. Foucault (1980: 142) also asserts that,

there are no relations of power without resistances; the latter are all the more real and effective because they are formed right at the point where relations of power are exercised; resistance to power does not have to come from elsewhere to be real, nor is it inexorably frustrated through being the compatriot of power. It exists all the more by being in the same place as power, hence, like power, resistance is multiple....

\footnotetext{
${ }^{20}$ I recognize that "Foucault is not disputing the existence of absolute or scientific truth, [but] merely stating his interest in the processes by which effects of truth are secured" (Barrett, 1991: 143).
} 
One of the key points that Foucault makes here, is that power and resistance are not necessarily exclusive, but that they always exist together. Foucault clarifies, though, that "one should not assume a massive and primal condition of domination, a binary structure with 'dominators' on one side and 'dominated' on the other, but rather a multiform production of relations of domination..." (Ibid.). In terms of the relations between the Cuban state and the local, and the actors therein, the picture that emerges from this research, then, is not one of sheer dominance. Although the Cuban socialist regime might be characterized in many ways by top-down bureaucracy (an issue which is extrapolated upon in Chapter 3), the state is not pitted against the local; rather, within these two scales, actors are engaged in a matrix of relational powers and resistances.

Power is expressed discursively; however, this thesis also explores non-discursive expressions of resistance. For instance, campesino resistance, in many ways, extends beyond discourses and is expressed in practice. Henri Lefebvre's thinking around the social production of space is useful here in that, in a sense, he seeks to bridge the gap between discourse and practice. Lefebvre (2000:4) critiques the incomplete picture that discourse analysis can provide:

Michel Foucault can calmly assert that 'knowledge [savoir] is also the space in which the subject may take up a position and speak of the objects with which he deals in his discourse.' Foucault never explains what space it is that he is referring to, nor how it bridges the gap between the theoretical (epistemological) realm and the practical one, between the mental and social, between the space of philosophers and the space of people who deal with material things.

In this way, Lefebvre understands discourse as tied to abstract space: the theoretical, mental, and space of philosophers. Lefebvre and Foucault, though, are not contradictory; rather they are complementary, for the objective of Lefebvre's (2000: 64) project is the "bringing-together of dissociated aspects, the unification of disparate tendencies and factors." Lefebvre, then, seeks to shift the focus from abstract space to a unity of the perceived, conceived and lived aspects of 
space. Briefly, these concepts refer to the material, the ideational ${ }^{21}$ ("associated with the totalizing and idealized visions that decision-makers and people in positions of authority, consciously or unconsciously, inscribe in space"), and the users of space, respectively (Premat 2009: 30$)$. For Lefebvre $(2000: 61,56)$ the perceived and conceived dimensions of space have been given priority over the lived, whereby the "passivity and silence of the 'users' of space" is endemic. No doubt, Lefebvre is a Marxist, and he focuses on lived space in terms of class struggle; in his thinking, the "users" of space can re-appropriate it, wherein re-appropriation functions to destabilize and transform conceived space and, thereby, the superstructure. In Cuba, the state and agricultural professionals promote particular practices associated with ideals of agro-ecology. This thesis, then, addresses the following questions in Chapter 5: to what extent do these ideal practices function to shape the spaces of farms? More pointedly, to what extent is resistance manifested in farm-spaces that do not conform perfectly to ideals of agro-ecology? Finally, theorizing local resistance in terms of lived space is yet another means to explore the multiple scales through which the Cuban agro-ecological movement operates.

\subsection{Conclusion}

Political ecology seeks to take into account both politics and ecology (Paulson et al. 2003: 205). As such, it studies "the workings of power on multiple scales and multiple contexts, developing an understanding of politics that goes beyond institutions of governance to encompass struggles over human practice, meaning, and representation in relation to the environment" (Paulson et al. 2003: 213). Through not only discourse analysis, but also an examination of the interplay between the discursive and the material, this thesis looks to such struggles as a means to better understanding the nuances of Cuba's transition to agro-ecology. Moreover, in presenting the

\footnotetext{
${ }^{21}$ Conceived space, or the ideational, according to my understanding, would include the abstract space (the theoretical, mental, and space of philosophers) of discourse.
} 
findings of this research project, Chapters 4, 5 and 6 develop the theoretical considerations introduced here in more detail. In the following chapter, I describe the methodological approach, and issues of this project; I provide details of my experience of Cuban bureaucracy and gatekeeping, and observations of Cuban life in general, which positions me as a student researcher within this multi-contextual landscape of power. 


\section{Chapter 3: Methodological Approach: Doing Research in Cuba}

\subsection{Introduction}

In October 2010, I made a preliminary one-week field visit to Sancti Spiritus, Cuba. I was invited by Deborah Henderson (Ph.D.), Director of Kwantlen Polytechnic University's Institute of Sustainable Horticulture in British Columbia. Deborah, whom I became acquainted with through a mutual friend, has conducted academic work in Cuba for over 10 years, and graciously offered to connect me with her contacts at the University of Sancti Spiritus (UNISS). ${ }^{22}$ I decided to tag along with the explicit purpose of garnering interest in my research, which at the time revolved around traditional environmental knowledge (TEK) among agro-ecological campesinos. Deborah and I spent several hours in the Dean of Engineering's office, casually discussing my research project with professors in the Faculty of Agricultural Sciences, and the Humanities Department, which includes Sociology and Cultural Studies. During this time, Deborah acted as not only my translator but also my cultural mediator. As such, she helped to reconcile my initial research interest with the faculty members' insistence that TEK was wiped out along with Cuban Indigenous during Spanish colonialism $\left(15^{\text {th }}\right.$ century). Through the fluid process of discussion and negotiation, I eventually came to the idea of investigating campesinos' preferences for using agro-chemical or agro-ecological practices.

This initial process of negotiation and discussion certainly foregrounds the contextual complexity with which this research unfolded. The purpose of this chapter is to delineate the methodology that this project employs, and to describe my own position as a novice studentresearcher. Section 3.2 highlights how I gained access to Cuban professionals and participants through what Deborah calls "partnering," and what I might call a pseudo-participatory approach; this process of partnering points to the way in which conducting research in Cuba perhaps differs

\footnotetext{
${ }^{22}$ The full name of the university is: University of Sancti Spiritus, José Martí Pérez.
} 
from other field experiences. Sections 3.3 and 3.4 provide details regarding my living conditions, and means of data collection, respectively. Also, given that I am not fluent in Spanish and worked with two translators, I discuss the power dynamics and co-construction of knowledge that transpires through the act of translation in Section 3.5. Finally, Section 3.6 explains my analytical approach, based on Foucauldian discourse analysis, and Section 3.7 looks at the ethical considerations of this project.

\subsection{Partnering}

The initial field visit in October 2010 resulted in the University of Sancti Spiritus' agreement to host me as a graduate student conducting fieldwork. A professor in the Marxism Department, Alberto Matias Gonzalez, who had done similar work among campesinos, was asked to act as my mentor. However, since the majority of Deborah's contacts are in the Faculty of Agricultural Sciences, this faculty took the responsibility of coordinating my research. Due to the fact that Cuba's bureaucracy was foreign to me, navigating it in order to set up my research was not a straightforward process. A number of institutions, in addition to the university, were involved in this coordination. First, a list of 40 potential producer-participants (belonging to CCSs) was compiled by CNSV field station employees in Cabaiguán and Banao, respectively. These employees are well acquainted with the campesinos in their regions, and identified campesinos as generational, non-generational, preferring agro-chemical or agro-ecological practices (I will discuss the discursive discrepancies of such categories in Chapter 5). Based on these identifications, I selected a sample of 16 campesinos. ${ }^{23}$ Next, the university submitted my sample to ANAP because, as outlined in the introduction of this thesis, CCS farmers belong to ANAP as members. In the past, tourists visited farms freely; however, the Cuban state considered this a

\footnotetext{
${ }^{23}$ This sample was later reduced to ten campesinos based on my mentor's suggestion. Taking into consideration my time frame of two months, I also felt that more time with less campesinos would be more methodologically appropriate for a Master's.
} 
transgression of the boundaries of tourist areas, potentially causing harm to campesinos (Ayala, primary translator/Biocontrol Specialist, CNSV, conversation, 2011) ${ }^{24}$ Therefore, today ANAP must provide explicit permission to farm visitors; otherwise, it is illegal to enter a campesino's property. Once I arrived in Cuba, moreover, ANAP requested a weekly plan detailing on which days I would visit certain farms. Finally, my primary translator was advised by ANAP to provide a courtesy call to the cooperative owners of the farms in my sample. This call was a matter of respect, as well as a token request for permission to visit a member-farm associated with their cooperative.

My research, then, has been mediated by several levels of gatekeepers, which put me in a relatively constant position of vulnerability. As not only a novice researcher, but also by virtue of doing work in Cuba I lacked a certain level of control over the fate and criteria of my project. ${ }^{25}$ Regarding the researcher-participant relationship, Ballamingie and Johnson (2011: 713) argue: "discussions about power relations in research are based on the (generally unstated) assumption that the researcher is the more powerful partner in the relationship, and must be highly sensitive to the needs of the less powerful research subjects." Throughout their article, though, these authors (2011: 715) debunk such power assumptions by detailing experiences of, for instance, "restricted access to key social actors." In this way, researchers are also vulnerable, whereby their capacity to conduct research is circumscribed by both individual and institutional gatekeeping. Indeed, the unique political context of Cuba heightens researcher vulnerability. For example, commenting on her own experience of visa restrictions in Cuba, Weinreb (2009: 71) recalls: "my sponsoring research center received a shadowy call from the [Cuban] Ministry of

\footnotetext{
${ }^{24}$ From the conversation, it was not clear how long ago this state requirement was instituted. ANAP has been in operation since 1961, but my sense is that the restricting of tourists visiting farms is concurrent with the rise of Cuban agro-ecology, and the international hype around this phenomenon.

${ }^{25}$ This lack of control is not unique to my research, as I explain later in the paragraph, but seems to be a common experience among foreign researchers who do work in Cuba (see Weinreb, 2009).
} 
Culture, saying my right to a yearlong visa was being immediately revoked." Hence, Weinreb's capacity to conduct research "was mysteriously revoked by the same 'invisible hand' that had procured it" (Ibid.). I too experienced certain unspoken restrictions. Although my sample was in large part pre-determined before entering the field, key informants suggested I visit other exemplary campesinos that were not on my list. Gaining access to these campesinos required persistence in the manner of repeated phone calls and visits to ANAP headquarters by my mentor, translators and me. In the end, ANAP gave access to two of the three additional recommended campesinos. The agro-ecological producer I was denied access to is known for his artistry in landscape design, beautiful use of fruit and flower trees, as well as his social frustration and alcoholism. Why I was denied access to this campesino was never clearly articulated to me.

In addition to the power dynamics between me, a Canadian graduate student researcher, and representatives from Cuban institutions, it is important to draw attention to the complex relations between campesinos and professionals working in the field of agriculture. Although a faculty member at the University of Sancti Spiritus described Cuban campesinos as "victims," he later said, "I don't know if victim is the right term." He explained that,

Before the Revolution farmers had been cheated by traders, or people who worked in the market. Farmers still retain this mentality of being cheated and so are a little suspicious. The fact that they are participating in the black market, makes them suspicious of questions regarding their use of chemicals. They won't be suspicious of you alone because you are a Canadian student, but if they see [us professionals] walking with that briefcase under our arm, they will think we are state security. Farmers generalize this lack of trust to many things, even to agro-ecology itself (interview, 2011).

As a result of the fact that my interviews were not conducted privately, one-on-one, but always with my translator, mentor, and often with other CNSV staff present, I was gently made aware that producers might not be completely forthright. At one point, it was suggested that I covertly 
record interviews, which I refused to do. Despite their relative vulnerability, CCS campesinos do retain power by virtue of the fact that they are private farmers: they exercise some control over the crops they plant, practices they use, and generally were shown to lead a higher standard of living than many urban-dwelling Cubans. Ultimately, I presented to campesinos as a young and curious, female Canadian student, who posed little threat. As such, it was my experience that despite some subtle resistance, producer-participants were generally open and forthright with their accounts.

Notwithstanding my inevitable vulnerability, the professional gatekeepers of my research also fulfilled a dual role as both guides and informants (Berg 2001). Certainly, at the institutional level, the University of Sancti Spiritus, CNSV and ANAP facilitated my ability to conduct research among Cuban campesinos; without such level of institutional support, it would have been extremely difficult, or impossible, as a Canadian student to negotiate the Cuban bureaucracy, as well as to gain access to the study population. On a personal level, the faculty and employees of these institutions were my key informants, providing me with invaluable information and time.

Furthermore, the development of my research project arose out of an iterative process that included one group of my study participants, the agricultural professionals. Faculty at the University of Sancti Spiritus, and CNSV staff that were directly related to my research conceived that the project could potentially contribute to agricultural extension initiatives focused on agroecology and food security. In this sense, the research I conducted parallels some aspects of participatory action research (PAR), such as supporting the study population's "participation in knowledge production and social transformation," and ensuring that the "ends and means" of the research are "grounded in guidelines established by the host community" (Kindon et al., 2007: 
10). Both the University of Sancti Spiritus and CNSV had expectations regarding the outputs of my research. I was asked to present my preliminary findings to the university's Faculty of Agricultural Sciences and Marxism Department before returning to Canada, and to submit a final copy of my thesis. Since CNSV staff was present during the interviews and farm tours, the outputs they received are less tangible. However, they were afforded the opportunity ${ }^{26}$ to build rapport and learn from campesino knowledge, and to make observations regarding potential points of intervention. For example, it was observed that the use of Trichoderma (see Table 1.2: Common Agro-ecological Practices) among campesinos in Cabaiguán was not widespread, a tendency that an CNSV employee attributed to the fact that "we [CNSV] are not doing our job" (conversation, 2011). It was also observed that the practice of using fruit and flower trees to promote farm biodiversity ${ }^{27}$ was not fully exploited among the majority of campesinos visited. In addition to what Bowen and Martens (2005: 203) identify as "the need to make research findings accessible to potential users," such outputs are applicable in the research setting.

\subsection{El Hotelito (little hotel)}

"The people here have, but they don't have" (CNSV employee, conversation, 2011).

During my two months of fieldwork, I lived at the University of Sancti Spiritus' graduate student residence, which also serves as a hotel for visiting professors and officials to the university. The majority of the time, though, I and the stray cat I befriended and fed on a daily basis, were the only guests. The hotelito (little hotel), however, did serve as home to the manager and his teenage son, and, in some sense, as a social venue for the other hotel staff. There was a receptionist at all times, who, if I was out late, slept in the front lobby until I came home. A

\footnotetext{
${ }^{26}$ It is important to note that although I was provided with a driver (either one of my translators, or one employed by the university) and vehicle, I paid for fuel. Gas and diesel are considered commodities outside of the purchasing power of many average Cubans.

${ }^{27}$ Throughout this thesis I use the term "farm biodiversity" because in the context of this research "biodiversity" refers exclusively to that which is created and conserved within farm-spaces, and agro-ecosystems.
} 
cook, who also fulfilled the duties of a cleaner, was present at intermittent times. Often in the afternoons into the evenings, hotel staff and a few of their friends, watched television in the lobby and chatted, or drank rum and beer, singing and playing guitar in the kitchen. I became, to a degree, integrated into this pattern and spent much time chatting, and sometimes drinking with the staff. When I first arrived at the residence, the cook prepared food for me, often a combination of boiled eggs, beans, rice, and fried fish, and I was served in the dining hall, separate from the kitchen. Eventually, I either ate in my room or in the kitchen with staff.

Despite becoming friendly with the hotelito (little hotel) staff, my status as an outsider was apparent, mostly in terms of my comparative wealth as a Canadian. For instance, the 5 liter bottles of water I bought regularly were beyond the purchasing power of average Cubans because they are sold in Cuban convertible pesos (CUC) $;{ }^{28}$ women staff always asked for the empty containers, presumably to be used in their own kitchens for fruit juice or tomato sauce. On the several occasions that staff came into my room to chat, or verify what time I would like to eat my meals, they asked how much one of my possessions, usually the pink closet organizer, cost and where I got it. I discerned that the interest in the organizer stemmed from the reality that many urban-dwelling Cubans live with their extended families in cramped spaces, where organization is a matter of importance. Moreover, as I became accustomed to buying fruits and vegetables from street vendors on bicycles, many hotel staff told me that they often could not afford to buy such produce, even though they were sold in "national money"(Cuban pesos). On a number of occasions, informants and friends voiced their material frustrations, saying "Our money is worth nothing."

\footnotetext{
${ }^{28}$ Cuba has two currencies: the Convertible Cuban Peso that tourists use, and is on par with the Canadian dollar; and the Cuban Peso that roughly values at 25 pesos to 1 CUC. I was told that the average Cuban monthly income is 12 CUC (300 Cuban Pesos); a higher-level position might obtain between 17 and 20 CUC (425-500 Cuban Pesos) per month.
} 
Indeed, exacerbating material frustrations in Cuba is the dual currency system, whereby imported commodities are valued in CUC:

I spent the afternoon with a friend browsing in la tienda [a boardwalk of stores that sell mostly imported commodities], checking out the prices of appliances: a double-door fridge, 1100 CUC; a washing machine that looks like something you would wash a doll's clothes in, 235 CUC. "How can Cubans afford to buy these things?" To which my friend responds, "Exactly" (field notes, 2011).

As I began to understand the limited access Cubans have to commodities valued in CUC, I also began to observe their informal coping systems. As Weinreb (2009: 67) describes, "To a certain extent, everyone is luchando [Spanish for fighting but struggling is more contextually apt] in the current regime, whether by pilfering goods from the state warehouse, working without a license, evading taxes on income, or avoiding state services through a black market network." On more than one occasion I witnessed, and participated in, the purchasing of foods like yogurt and tomato sauce processed in the homes of Cubans, packaged in recycled plastic and glass bottles, and sold by word of mouth, without a license. The "illegality" of such practices did not concern me; however, the reality that in one hour in la tienda I could spend the equivalent of what an average Cuban makes in a month (12 CUC) created a constant sense of discomfort, guilt, and a heightened awareness of my incumbent difference.

\subsection{El Campo (the country)}

I conducted semi-structured interviews with 20 participants, grouped either as professionals or producers. Interviews were recorded, and transcribed from translation. I entered the field with a standard interview questionnaire for both groups of participants (see Appendix B: Interview Guides). The professional's questions were adapted according to what I learned in conversation about their work or personal history. My mentor and my primary translator vetted the producers' questions; although most questions were deemed unproblematic, my mentor, who grew up in a 
farming community, highlighted some issues with terminology, and also suggested themes that might draw out more information regarding campesinos' environmental ideologies. To set up interviews with the professionals, I followed a snowball sampling technique where my translators and informants made suggestions for potential interviewees. I interviewed one professor from the University of Sancti Spiritus (my mentor), five current or past staff of CNSV (four senior and one junior), the lead coordinator of ANAP's Farmer-to-Farmer movement for Sancti Spiritus, and the director of the Cuban Association of Agricultural and Forestry Technicians (ACTAF) in Sancti Spiritus. Present at these interviews, which took place in my residence, or at the professional's office or home, were a translator, the interviewee and myself. In terms of the producers, I interviewed 12 campesinos belonging to various CCSs in the province of Sancti Spiritus. I interviewed five producers from the municipality of Cabaiguán, and five from the town of Banao, which is within the municipal limits of Sancti Spiritus. While discussing the parameters of this research with faculty at the University of Sancti Spiritus, these two regions were identified as having less developed agro-ecological methods, but also as being nationally important in that they are highly agriculturally productive regions. The producers were chosen based on their tendency to use agro-ecological or agro-chemical practices, as well as their generational history as campesinos. Generational farmers were included as part of the sample in order to obtain personal testimonies regarding how family tradition might impact the choice to use chemical-based or ecological practices. The final two campesino-participants are from the municipalities of Sancti Spiritus ${ }^{29}$ and Taguasco, and are well-known as ANAP promoters, committed to agro-ecology (Chapter 5 discusses both the implications of being an ANAP promoter). These additional campesinos were included as participants after recognizing that my sample was limited, in the sense that I could not ascertain a clear difference between the ten

\footnotetext{
${ }^{29}$ Sancti Spiritus is the name of a province, municipality and capital city.
} 
Figure 3.1: In the Field

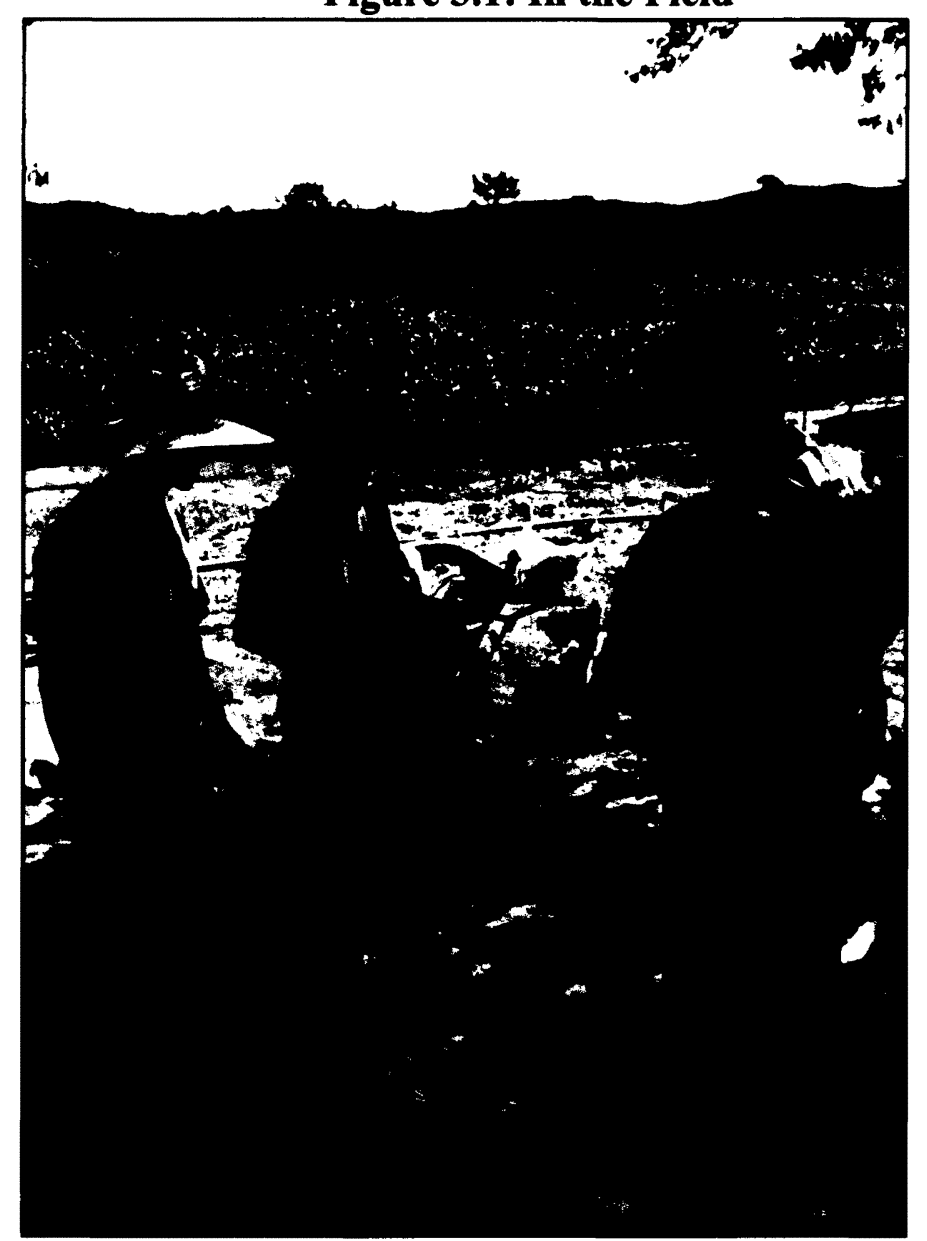

From left to right: Farm Technician, Gomez (Institutional Communicator, CNSV) and Ayala (Primary translator, Biocontrol Specialist, CNSV)

producers from Cabaiguán and Banao that supposedly preferred agro-chemical or agro-

ecological practices. Although, I was surprised by this limitation, it foregrounds the complexity of the transition to agro-ecology that this thesis grapples with.

I spent roughly fourteen ten-hour days visiting farms, and conducting interviews with campesinos. I met three campesinos once, and visited the remaining nine between two and four times, with visits usually lasting two and a half to four hours. A typical field day began at eight a.m. when my driver would pick me up at my residence, and usually consisted of doing two interviews, and one farm tour. Campesinos that were visited in the morning generally asked us to stay for lunch, which allowed for casual conversation, including the chance for interviewees to 
ask questions about me. After picking me up, my driver would collect my mentor and translator at their respective homes, or the university, and get gas en route to the farm or the campesino's home (generally 30 minutes by car outside the city). In the case of Banao, once we arrived we picked up Ruperto Gomez, Institutional Communicator for CNSV's Banao field station. Ruperto's participatory method of work made him a highly valuable informant; for instance, he considers that "the essence of [agricultural] extension" hinges upon building rapport with campesinos and their families by sharing in their successes and difficulties as food producers (interview, 2011). Thus, Gomez's close relations with the farmers of Banao created a convivial and comfortable atmosphere during data collection. However, I also witnessed moments during which farmers proved hesitant to share experiences and practices that ran counter to Gomez's spirited promotion of agro-ecology. For this reason, after conducting each interview, I recorded my impressions of how it transpired.

We were often greeted at producers' homes with coffee and introductions to the family. Interviews generally took place in the living rooms of their homes, lasting between one to two hours (with two exceptions where interviews took place in a barn). Although interview sessions were informal with the professionals, the sessions unfolded with even less formality in the case of the producers. In this way, there tended to be more observers and conversers present during interviews with campesinos, which had a dual function. In one sense, the fact that interviews unfolded in a group atmosphere facilitated a more fluid discussion. In what follows, the campesino-participant, Ayala (primary translator/Biocontrol Specialist, CNSV), and Gomez (Institutional Communicator, CNSV) discuss the agricultural trend toward diversification of crops: 
PRODUCER 5: I have lemon, I have banana, I have yucca, beans...

AYALA, GOMEZ, PRODUCER 5 (summary of discussion): Come to the conclusion that one of the changes during the last years is that many of the farmers now use diversification of their crops; the conception regarding "monocrop" production has changed.

AYALA: He [referring to the producer] also learned in the field that some crops are not good for example as [planting] corn after onion because they will affect the soil fertility. He has a diversified farm but also understands the need and how to rotate crops.

In another sense, though, such discussions that took place during interviews were often lengthy, and challenging for the translator to provide a detailed summary of all that had been said, including nuances in the conversation.

With regards to participant-observation, it is important to note as a methodology, it is not bound by scheduled activities. As Wolcott (2005: 89) maintains: the "essence" of participantobservation "is captured, although oversimplified, in the phrase 'being there'." He goes onto explain that participant-observation consists of achieving a balance between participating and observing, but that regardless of this balance, being in the field is always a "self-conscious" endeavour (Ibid.). In this sense, I made a number of observations regarding the interaction, and power dynamics between professionals and producers, which I expand upon below. In addition, my observation of black market activity in the quotidian lives of Cubans has provided me with a more keen insight of how material and resource limitations figure into the lives and work of rural campesinos. My participation in the Cuban way of life, then, is part of the contextual fabric that makes up my understandings and insights into Cuban agriculture, and the social actors directly linked to it. Formal participant-observation activities consisted of attending (as a spectator) a conference in Havana on the subject of biological controls, observing one agricultural extension workshop provided by ANAP, and participating in farm tours, which consisted of the campesinos explaining the layout of the farm, their practices, and crops. During these tours, and with the campesino's permission, I took extensive photographs; afterwards, I took thorough field 
notes. On several occasions (with either the campesino's invitation or permission), I returned to farms hoping to help plant crops; however, planting is highly dependent on rain and each time I arrived, the soil was either too wet or too dry. Such return visits were not lost, though, as producers were not busy planting, and had time to converse casually.

\subsection{Translation as Co-construction}

In an article that addresses the invisibility of translation in qualitative research, Temple and Young (2004) maintain that the act of translation is neither neutral, nor objective. Indeed, in poststructuralist fashion, they state that "Speaking for others, in any language, is always a political issue that involves the use of language to construct self and other." Implicit within the act of translation, then, are relationships of power and authority. For the purposes of this research, I worked with two translators: Jorge Luis Ayala Sifontes who works as a Biocontrol Specialist with CNSV, and as such is an agronomical engineer; and Elba Maria Ferrer, English professor at the University of Sancti Spiritus. Interestingly, Ferrer's profession is not aligned with agriculture; thus, due to her lack of agronomical knowledge, she appeared to producers as less of a threat. On the contrary, Ayala's professional status gave way to certain power dynamics that emerged during data collection. For instance, a discourse regarding professional and scientific versus farmer knowledge became apparent. Both professionals and campesinos referred to farmer knowledge as something that is empirical, derived from observation but not from "proper" education. As one campesino put it, "I was doing permaculture without knowing I was doing permaculture" (Promoter A, interview, 2011). Certainly, within the distinction between knowledges there is a bias toward professional knowledge; campesinos and professionals alike highlighted their recognition of this bias: 
CNSV EMPLOYEE: We teach but we learn. Actually, we don't learn but we feel satisfied when we see that they [farmers] are doing what we teach them (interview, 2011).

PRODUCER 8: I know why I have a high yield, but it is not the same as being [an agricultural] technician or an [agronomical] engineer (interview, 2011).

In some cases this power dynamic brought to the fore resistance on the part of the farmer:

AYALA: In general, how many chemical treatments do you do?

PRODUCER 4: In the case of the production of bulbillos [small onion bulbs that are planted in fields in order for the onion to grow to maturity] the right time is between December and January and needs more chemical because this is the part of the year when several pests attack onion more intensively. I treat them with insecticide three to four times a week to control the pest.

AYALA: If the pesticide is really good and you kill the insect today, three days later, there won't be any pests left to treat.

JOHNSTON: But you should not say that, you should let him [the producer] talk.

AYALA: No, because if I do not ask him [the producer], he will not tell me. It is necessary to provoke (interview, 2011).

The discussion above is fraught with subtle resistance; on one hand, there is conflict between the ideological stances of Ayala and the producer. Among many producers, there is an entrenched belief that chemical inputs are to be used in a preventative fashion. What this means is that producers will use chemical pesticides and fungicides regardless of whether they observe pests or diseases in their crops. On the contrary, CNSV, as a state body, recommends the rational (minimal) use of chemical inputs, which often entails treating for pests and diseases only if they are present in the crop. ${ }^{30}$ Hence, Ayala "provokes" the producer into giving us an honest description of his chemical use, which illustrates the unspoken bias that rational use is the correct strategy. On the other hand, there is some friction between Ayala as my translator, and me. As a researcher, my goal was not to "provoke" but to provide an open, amicable atmosphere within which producers could feel comfortable to voice their positions. Despite the few moments where campesino-resistance to state recommendations regarding appropriate doses of chemical

\footnotetext{
${ }^{30}$ This ideological stance follows from Integrated Pest Management (IPM) (Table 1.2: Common Agro-ecological Practices).
} 
products was made explicit, it was my experience that most campesino-participants were candid. Also, in discussing such power dynamics, and as noted earlier, my sample consisted of relatively wealthy campesinos, whose power lies explicitly within the societal recognition that they are the food producers of the nation.

Related to such issues of power and knowledge is the misassumption that translation also functions as neutral interpretation; however, as Wong and Poon (2010: 152) aptly remark, "People within a specific so-called cultural community do not necessarily share the same worldview, values, morals, or understanding of what constitutes their collective culture." As such, the act of translation functions as one of co-construction: "The translator always makes [her] mark on the research, whether this is acknowledged or not, and in effect some kind of 'hybrid' role emerges in that, at the very least, the translator makes assumptions about meaning equivalence that [makes her] an analyst and cultural broker as much as a translator" (Temple and Young 2004: 171). During the interviews, I consistently asked the translators and participants, "What do you mean?" Such questioning foregrounds the process of co-construction, whereby plural positions are forged into a common understanding. Also, following interviews and farm tours, I frequently discussed with my translators and mentor what we had heard and seen. In other words, I sought out their interpretations as not only a means to understanding their positions, but also as a way of enriching my own understanding. To this end, Temple and Young (2004: 170- 71) state that "if we treat interpreters as 'key informants' rather than as neutral transmitters of messages, then a conversation about possible differences in perspectives can begin. ${ }^{31}$ Finally, during transcription, I came across several instances where my understanding

\footnotetext{
${ }^{31}$ In order to differentiate my own perceptions from that of my key informants, it is important to note that I interviewed my primary translator (Ayala, Biocontrol Specialist, CNSV) and my mentor (Gonzalez, Professor, Marxism Department, UNISS) as means to better understanding their positions, biases, assumptions, experiences and histories with regards to agriculture and farmers in Cuba.
} 
of the various nuances of the discussion was more complete than that provided by the translator, as well as points where questions were asked in a different way than I had intended. In order to make visible, then, the co-construction of my data, I will highlight points at which my translators made personal interpretations rather than literal translations; also, interview quotes throughout this thesis are only edited at points where clarification was needed, so as to not silence the translators' voices.

\subsection{Analysis}

The intent of my analysis strategy was to take a Foucauldian approach. As Waitt (2005: 176) explains, the "Foucauldian strand of discourse analysis" seeks to "investigat[e] the consequences of how specific sources (institutions, subject-positions) produce particular subjectivities and meanings about the social relationships between objects, people, and places." My sources of analysis consist of interview transcripts, field-notes, photographs of discursive representations in public spaces, a state document, ${ }^{32}$ and CNSV and ANAP publications. I conducted an iterative thematic analysis with these sources in order to determine a coding scheme; these codes referred to the positions and underlying ideologies, silences and contradictions that were identifiable between professional and producer discourses.

With regards to this strategy, I must foreground my Spanish fluency. When I entered the field I had a basic level of comprehension and verbal ability. However, my comprehension skills improved rapidly given the fact that I knew only four people who spoke English, and was left to my own devices to function in daily life. I also spent several hours a week self-studying, reading short articles from agricultural extension magazines, and working with a Linguistics professor at the University of Sancti Spiritus. Upon my return to Canada, I have also continued to self-study,

\footnotetext{
${ }^{32}$ This document of guidelines (lineamentos), which was released during my field research, outlines the future directions/projections of the Cuban nation as decided upon during the $6^{\text {th }}$ Congress of the Communist Party of Cuba in 2011.
} 
and take classes in Spanish. Ultimately, I believe that the amount of time I spent discussing my observations with CNSV staff, and faculty at the University of Sancti Spiritus facilitated my capacity to understand and interpret the intricacies of the various discourses addressed in this thesis.

\subsection{Ethical Considerations}

In order to maintain standards of transparency and accountability, informed consent was obtained from each participant in this study. Prior to conducting interviews, I presented participants with a Letter of Information and Consent Form (see Appendix C: Letters of Information and Consent Forms) in Spanish. In addition to this form, my Cuban translators, mentor and I informally gave background information regarding my purpose and position as a Canadian graduate student to participants. During interviews, I ensured consent before starting the digital recorder, which was always placed in plain sight. Professional-participants were not offered confidentiality or anonymity as their status and titles lend credibility to the research; however, based on my own discretion, I have provided non-attribution to certain excerpts and testimonials that I considered to have the potential to harm or affect the professional. Producers' names are omitted in this thesis, but it was not possible to provide them with confidentiality given the bureaucratic process involved in gaining access to this study population. Faculty at the University of Sancti Spiritus, and agricultural extension workers from CNSV and ANAP know the identity of the producers in my sample. Both professionals and producers were made aware of the opportunity to retract statements, although no one felt the need to do so.

Although my translators signed confidentiality agreements, family members and farm workers were also often present during interviews and field visits; in order to maintain a socially convivial atmosphere, and to respect cultural norms, I did not feel that I could ask these people 
for confidentiality or to leave. Given this level of informality, campesinos were comfortable, for the most part, alluding to their participation in certain illegal activities, such as purchasing chemical agricultural inputs on the black market. It is well-known by Cuban professionals that campesinos participate in the black market, and I do not believe that these discussions put producer-participants at risk, or that professionals present during the interviews will report this activity to state officials. It is important to recognize, as I note above, that most Cubans are luchando (struggling to survive), and as such, participate in some form of illegal market activity. Furthermore, agricultural professionals are typically passionate about working with, not against, campesinos in order to further the agro-ecological project. Thus, extension workers are keen to develop rapport and trust in farming communities.

With respect to reciprocity, my main source of compensation to participants and informants was in the form of gifts. Wolcott (2005: 84- 5) asserts that, "fieldwork entails a subtle kind of exchange, one that often involves gifting across cultural boundaries where exchange rates may be ambiguous or one wonders what to offer in exchange for intangibles such as hospitality or a shared life history." To be sure, I was concerned with the apparent superficiality associated with monetary and material gifts. But, given the material constraints that Cubans live with, gifts were always accepted with sincere gratitude. In exchange for CNSV's participation in my research, I was asked to provide a donation of computer electronics. For the translation services of Professor Elba Maria Ferrer, I paid a small sum of money to the University of Sancti Spiritus. Finally, my daily rent at the hotelito (little hotel) was considered a donation to the university in reciprocity for their support. With producers, I respected the few requests that they made of me. For instance, one campesino asked for a copy of the interview recording; another asked for copies of the pictures I took on his farm. Other campesinos expressed interest in learning about 
an agro-ecological practice known as "effective microorganisms" (see Table 1.2: Common AgroEcological Practices). In these cases, we returned to the homes and farms of these campesinos to distribute brochures produced by "Indio Hatuey" Pasture and Forage Experiment Station (EEPF) regarding this practice. Finally, in addition to providing the University of Sancti Spiritus with a copy of my thesis, a selection of the results of this project will be disseminated to the participants in a brochure or a newsletter.

\subsection{Conclusion}

Evidently, this research project has unfolded with a great deal of complexity, which is attributable to contextual issues: first, I was enmeshed within a dynamic of partnering with the University of Sancti Spiritus and CNSV, wherein I had to rely on the faculty and staff of these institutions for not only housing and transportation, but also for guidance and translation; second, partnering with agricultural professionals certainly gave way to subtle power struggles between professionals and producers; thirdly, my sample and field experiences were subject to ANAP's and CNSV's gate-keeping. The amount of data collected (20 interviews, numerous field visits and photographs), in addition to working with two groups of study participants (professionals and producers) has created depth to the project, despite the fact that data analysis was challenging. Importantly, the level of institutional and campesino support that this research project received attests to its local relevance. As Berg (2001: 45) notes, an ethnographic study must be understood by participants as worthwhile and meaningful. The next chapter grapples with the discursive discrepancy between how professionals and producers understand food security, an issue that is certainly politically salient in Cuba today. 


\section{Chapter 4: Food Security as Discourse}

\subsection{Introduction}

On the road to Cuba's National Institute of Plant Protection's (CNSV) Banao field station, there is a red and yellow billboard that reads: producir alimentos esencial para recuperarnos, which means "to produce food is essential (necessary) for us (for Cuba) to recover (recuperate)" (see Figure 4.1: Signage on the Road to CNSV, Banao Field Station). Interestingly, the billboard combines sentiments of nationalism and economic recovery with food security, and no doubt, alludes to the state initiative to reduce imports through the local production of cultivos potenciados (enhanced or prioritized crops). Moreover, words such as "essential" and "recuperate" are in line with what Premat (2009: 33) aptly terms "government discourses" of "food insecurity and the national struggle for survival."Although Premat is referring to the Cuban state's response to the scarcity brought on by the economic collapse of 1989 , food security still figures significantly within the current socio-political regime. However, as Premat indicates in her characterization of "government discourse," food security is predominantly a professional discourse employed by government officials, scientists, and agricultural extension workers. In keeping with a political ecological approach, the aim of this chapter is to deconstruct the plural positions toward food security in terms of how this professional discourse is interpreted and enacted by producers.

Section 4.2 proceeds by demonstrating that professional interests with regards to food security are motivated by nation-wide concerns that revolve around fulfilling population needs; creating crop diversity is one way to fulfill such needs. However, as outlined in Section 4.3, from a professional perspective, the importance of diversity is also linked to scientific concerns over the preservation of farm biodiversity. 


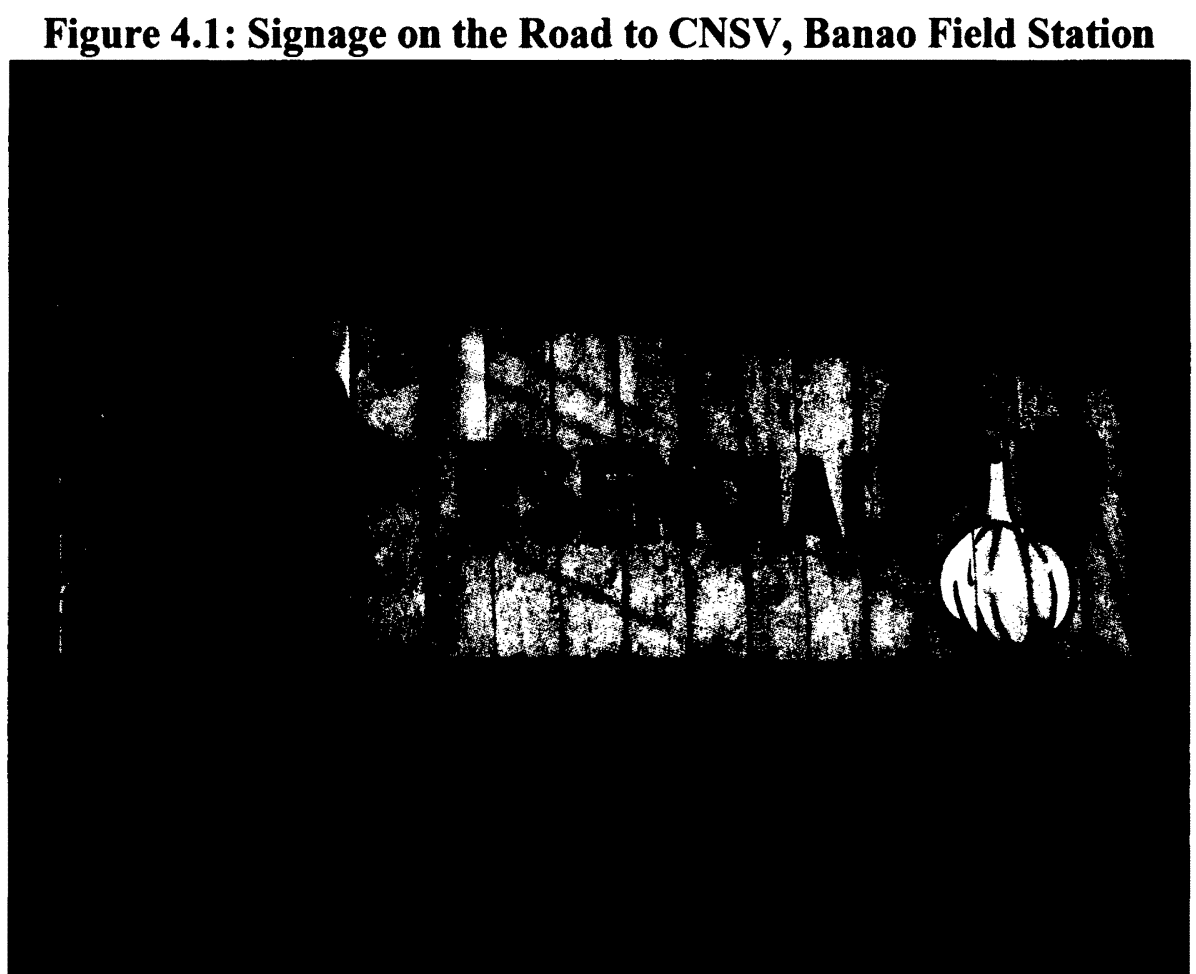

Translation: to produce food is essential (necessary) for us (Cuba) to recover (recuperate).

As Escobar (1998: 55) makes clear, though, the scientific preoccupation with biodiversity "goes well beyond the scientific domain." Escobar points to Foucault's contention that the deployment of discourses like biodiversity is attached to certain truths, as well as the interests of particular groups of social actors. In this way, as Section 4.4 shows, professional efforts to conserve and create biodiversity on farms are not solely scientifically, or ecologically, motivated, but are conflated with national security. Ultimately, tying such biodiversity to national security strengthens the agro-ecological agenda, and as Castillo (Coordinator, Farmer-to-Farmer Movement, ANAP) asserts with fervour: "Agro-ecology is a necessity, and obligation of human beings. It is the only way to continue living on this planet, and to have food security" (interview, 2011).

As distinct from professionals, though, Section 4.5 outlines that campesinos relate food security to their ability to produce food, which is intimately connected to their access to resources, and technical skill. Such ability, in turn, is embedded within larger concerns of 
livelihood, family sustenance and economic security. These concerns do not necessarily conflict with the paradigm shift to agro-ecology; for example, state and professional actors are working to build food security by encouraging practices that are more ecologically and economically efficient. As Funes et al. (2002: 146) explain:

Traditionally small-scale producers [in Cuba] have intercropped their sugarcane with short-cycle crops such as common beans, tomatoes, peanuts, and soybeans. Similarly, the open space between rows in plantain or fruit orchards was frequently used to cultivate annual crops. These intercrop systems had higher total productivity, greater crop diversity, made more efficient use of available resources, with the added benefit of reducing pest, plant diseases, and weed levels, making them more profitable.

These authors (2002: 52) further contend that the Cuban government seeks to increase food security by "revalu[ing] the family farm economy." It is important to recall, here, that my sample of producer-participants is derived from Credit and Service Cooperatives (CCS), which are based on the family farm model. Thus, given the state endorsement of the traditional purposes of smallscale agriculture, it is hardly surprising that modern campesinos are preoccupied with economic stability and family sustenance. However, the discrepancies between how professionals and producers talk about food security serve to expose some subtle resistance to, and friction with the state's agro-ecological agenda.

\subsection{What is Food Security?}

In a discussion about how to define food security, Ayala (primary translator/Biocontrol Specialist, CNSV) directed me to the definition set out by the Food and Agricultural Organization (FAO). Cuban professionals often subscribe to a discourse of food security that parallels international standards, which is apropos given that Cuba figures predominantly in the global conversation regarding sustainability and food security. Also, the FAO definition is in line with the goals of Cuba's national programs that have been implemented to address food 
shortages. ${ }^{33}$ According to the FAO, food security is "a situation that exists when all people, at all times, have physical, social and economic access to sufficient, safe and nutritious food that meets their dietary needs and food preferences for an active and healthy life" (FAO 2002). The key components of this definition revolve around access, quantity, nutrition, and choice. When I asked, "What does food security for Cuba mean to you," most professionals I interviewed included a combination of these components in their responses (see Table 4.1: How Cuban Professionals define Food Security as Compared to FAO Definition). For instance:

PALENZUELA (President, ACTAF): To have the necessary foods-- necessities, and variety- to be able to live like a human, access to products (interview, 2011).

AYALA (primary translator/Biocontrol Specialist, CNSV): Is to have enough quantity, diversity, and quality of food available for you to select what you want to eat every day during all the life. For me quality include no residual of pesticide. No pesticide at the level, for now, that could create [health] problem.... Of course it is an ideal to have the opportunity to eat many things because at last nutrition is dependent upon food diversity, source of nutrients you eat (interview, 2011).

Phrases like "food available for you to select what you want to eat every day during all the life" and terms like "variety" refer to such conditions as access, choice and quantity. While Ayala explicitly refers to nutrition, Palenzuela alludes to it with "variety." As Ayala asserts, nutrition is dependent upon the consumption of a diversity, or variety of foods. He explains: "For example, if [this farmer] produces beans and onion, and another produces rice and milk, and another produces green beans and tomatoes... for everybody to be able to eat all that we can produce" (in Producer 4, interview, 2011). Each producer contributes certain crops and foodstuffs, and shares in the responsibility of food security for the country.

\footnotetext{
${ }^{33}$ Such programs seek: "to provide follow-up and evaluation of the nutritional and food status of the population, and adopt appropriate preventive health measures; to increase the amount and the nutritional quality of national food production; to guarantee food availability to all Cubans and provide food and nutrition assistance to vulnerable groups" (Funes et. al., 2002: 50).
} 
Table 4.1: How Cuban Professionals define Food Security as Compared to FAO Definition

\begin{tabular}{|c|c|c|c|}
\hline Participant & Affiliation & Response & Link to FAO \\
\hline $\begin{array}{l}\text { Ruperto } \\
\text { Gomez }\end{array}$ & $\begin{array}{l}\text { Institutional } \\
\text { Communic- } \\
\text { ator, CNSV }\end{array}$ & $\begin{array}{l}\text { No external dependency; security in the } \\
\text { quality of the food; the guarantee of our } \\
\text { and animals' nutrition; so nutrition, food } \\
\text { supply, quality, and no external } \\
\text { dependency [Ayala interprets this as } \\
\text { quantity]. The balance between quantity } \\
\text { and quality (5). }\end{array}$ & $\begin{array}{l}\text { Access, quantity, } \\
\text { choice: "food } \\
\text { supply" } \\
\text { - Nutrition: } \\
\text { "nutrition" }\end{array}$ \\
\hline $\begin{array}{l}\text { Paula } \\
\text { Quintana } \\
\text { Palenzuela }\end{array}$ & $\begin{array}{l}\text { President, } \\
\text { ACTAF }\end{array}$ & $\begin{array}{l}\text { To have the necessary foods } \\
\text { (necessities), variety- to be able to live } \\
\text { like a human, access to products ( } 3 \text { ) }\end{array}$ & $\begin{array}{l}\text { - Access: "access" } \\
\text { - Quantity, choice: } \\
\text { "variety" } \\
\text { - Nutrition: } \\
\text { "necessary foods" } \\
\text { and "variety" }\end{array}$ \\
\hline $\begin{array}{l}\text { Jorge Luis } \\
\text { Ayala } \\
\text { Sifontes }\end{array}$ & $\begin{array}{l}\text { Biocontrol } \\
\text { Specialist, } \\
\text { CNSV }\end{array}$ & $\begin{array}{l}\text { Is to have enough quantity, diversity, and } \\
\text { quality of food available for you to select } \\
\text { what you want to eat every day during } \\
\text { all the life. For me quality include no } \\
\text { residual of pesticide; no pesticide at the } \\
\text { level, for now, that could create [health] } \\
\text { problem.... Of course it is an ideal to } \\
\text { have the opportunity to eat many things } \\
\text { because at last nutrition is dependent } \\
\text { upon food diversity, source of nutrients } \\
\text { you eat (9). }\end{array}$ & $\begin{array}{l}\text { Access, quantity, } \\
\text { choice: "enough } \\
\text { quantity, diversity, } \\
\text { and quality of } \\
\text { food available for } \\
\text { you to select what } \\
\text { you want to eat } \\
\text { every day during } \\
\text { all the life" } \\
\text { Nutrition: } \\
\text { "nutrition" and } \\
\text { "food diversity" }\end{array}$ \\
\hline $\begin{array}{l}\text { Sylvia } \\
\text { Monzon }\end{array}$ & $\begin{array}{l}\text { Retired } \\
\text { Biocontrol } \\
\text { Specialist, } \\
\text { CNSV }\end{array}$ & $\begin{array}{l}\text { The capacity the country has to } \\
\text { guarantee the food supply of the people } \\
\text { through sustainable and ecological } \\
\text { production; a production that takes into } \\
\text { consideration the environment [Ayala } \\
\text { interprets this to mean quantity and } \\
\text { quality.] Food with the minimum } \\
\text { possible level of chemical residues (4). }\end{array}$ & $\begin{array}{l}\text { - Access, quantity: } \\
\text { "guarantee food } \\
\text { supply" } \\
\text { - Nutrition, choice: } \\
\text { "ecological } \\
\text { production" }\end{array}$ \\
\hline
\end{tabular}

\subsection{Security in Diversity}

Indeed, within the political agenda to build food security, there has been a strategic move by the state and agricultural extension workers to increase crop diversity. However, diversity is not only tied to ensuring a variety of foodstuffs to the population; farm biodiversity, from a scientific standpoint, is also important, and is most often achieved in an agro-ecosystem through 
intercropping. ${ }^{34}$ In the following excerpt, Ayala (primary translator/Biocontrol Specialist, CNSV) describes farm biodiversity from a scientific standpoint, and as it is most often subscribed to by agricultural extension workers:

I think you have to start from the point that when humans do agriculture, you are disturbing the natural environment. And in the natural environment, you have very wide biodiversity, but when humans eliminate all this diversity of plants to put the plants that they want to produce food, it simplifies the environment, and the insect and all the organisms that depend on this specific plant, to feed on it, will increase its [the insects and organisms] population in this place. So if humans make an alteration in the ecosystem, they could introduce a way to solve this problem. Chemical [pesticides and fertilizers] is one solution but to use the proper force of nature, the bio-regulator, is our [CNSV's] ideology.... (in Monzón interview, 2011).

Bio-regulators are what Funes et al. call "beneficial insects" and "natural enemies" (footnote 5).

The idea is to recreate an agro-ecosystem based on relationships between the plants and insects attracted by those plants. As Palenzuela (President, ACTAF) explains, in a truly biodiverse farm there are no "pests" because the agro-ecosystem is functioning as a whole, and each organism is integral to that functioning (interview, 2011).

The scientific concept of farm biodiversity is indicative of a "knowledge of nature" that dominates professional interests regarding food security. This knowledge revolves around the positivistic notion that biodiversity is "a true object that science progressively uncovers" (Escobar 1998: 54). Escobar problematizes this notion, though, and exposes the way in which biodiversity as a discourse deploys various "truths" in service of the different interests of groups of actors.

\footnotetext{
${ }^{34}$ Funes et al. (2002: 145) explain: "Intercrops or polycultures-which can be used to reduce monoculture and its negative impacts - can be defined as the production of two or more crops in the same area, during the same year. By sowing consecutively or in association agricultural production can be made more efficient by making better use of space and time." One way to practice intercropping is to create living barriers, which is considered a form of biological control. A living barrier is essentially a crop that is introduced into an agro-ecosystem to manage pest and disease infestation: "One crop can function as a physical barrier to pest movement between the rows of another crop, and/or insect pests can be confused by the odors and colors of the different crops. Thus, the rate of pest invasion, dissemination, and reproduction can be lower in polyculture systems than in monocultures. One crop can also provide a habitat or refuge, and/or supplemental food source such as nectar, attracting beneficial insects that may be natural enemies of the pests of another crop in the same system" (Ibid.).
} 
He writes:

Foucault (1980) suggested that 'sex' does not exist, but that it is an artificial construct required for the deployment of sexuality as an historical discourse. Is biodiversity similarly the construct around which a complex discourse of nature is being deployed? If this is so, then, as in the case of sexuality, the biodiversity discourse would anchor an entire apparatus for the dispersion of new truths throughout vast social domains (Ibid.).

Using a political ecological framework, Escobar presents a case for how biodiversity is not only deployed by hegemonic social actors to achieve certain ends, but also functions as a site of social mobilization, around which Indigenous and local groups can assert their rights and perspectives. My intention here is not to launch a similar argument regarding the social mobilization of Cuban campesinos, but to simply point out that the Cuban state's goal of building food security through diversity serves the specific scientific interest of also conserving biodiversity on farms. In Foucauldian terms, casting biodiversity in objective scientific terms, obscures the "determinative powers of discourse in constituting practices that are intimately responsible for..." how people live, think and speak (Barrett 1991: 131). Moreover, emphasizing the scientific import of farm biodiversity, in some ways, overshadows the fact that state-level strategies to augment food security are intimately interwoven into the lives and work of campesinos.

\subsection{National Security}

The discourse of food security is bound to scientific interests of conserving and creating biodiversity on farms; yet, such biodiversity is also tied to concerns over national security. For instance, during an informal conversation, I witnessed a number of agricultural professionals sitting around discussing Cuba's vanguard means of supporting food security through the operation of seed banks. Apparently, Cuba has seed banks spread throughout the country, with the explicit purpose of maintaining genetic and biological diversity; such banks store various strains of seeds-heirloom and new varieties-- for planting in the case that seed reserves are 
destroyed through natural disasters, disease, war, etc. Essentially, the conversation ended when Palenzuela (President, ACTAF) firmly stated: "Food security is national security," and all parties agreed. A similar sentiment is expressed in the following excerpt:

[Food security is] what you [your family and the state] really need without external supply. Need has to do with nutrition, and diversity that guarantees the development of life [for healthy development, one must consume a diversity of foods]. That farmers can supply a diversity of products to the market-- in case of hurricane or a difficult season, a diversity of crops acts as a protective measure in case some crops are damaged. Diversity is according to nature and environment-- without biodiversity, you cannot have security (Promoter B, informal interview, 2011). ${ }^{35}$

Here diversity is tied to the notion of "protection" in two ways: firstly, intercropped systems can protect against damage due to natural disasters, pests, and diseases through living barriers, and crop rotations; and secondly, intercropping also works to ensure that the needs of the population are met by providing a diversity of foods to the market. Thus, by protecting the Cuban environment and population, the nation is secure.

Also implicit within the relation of food security to national security is the professional concern for the internal capacity of the Cuban nation to produce food. In discussing what they consider food security to be, Gomez (Institutional Communicator, CNSV) and Monzón (retired Biocontrol Specialist, CNSV) express this professional interest:

MONZÓN: The capacity the country has to guarantee the food supply of the people through sustainable and ecological production; a production that takes into consideration the environment [Ayala interprets this to mean quantity and quality.] Food with the minimum possible level of chemical residues (interview, 2011).

GOMEZ: No external dependency; security in the quality of the food; the guarantee of our and animals' nutrition. So nutrition, food supply, quality, and no external dependency

\footnotetext{
${ }^{35}$ Although this is the testimonial of a campesino, not a professional, he is an ANAP promoter. I will discuss the implications of this role in the next chapter; suffice to say that ANAP promoters are considered exemplary producers, and similar to agricultural extension workers, they teach the agro-ecological method to other farmers. Also, this particular promoter is educated as an agricultural technician. Hence, it follows that he would subscribe to an understanding of food security that is aligned with a professional stance.
} 
[Ayala interprets this as quantity]. The balance between quantity and quality (interview, 2011).

These professionals make reference to "no external dependency" and "the capacity the country has to guarantee the food supply of the people through... production," respectively. Indeed, other professionals also highlight such capacity, saying that food security is:

The capability of a country to produce their own food for their people with the resources they have.... The political will of the country to dedicate all resources needed to produce the necessary food for the people (Pérez, previous Director, CNSV, interview, 2011).

To substitute importation, and that land owners diversify crops in their farms.... This political strategy at the level of the country-- to give new lands... will achieve food security (Castillo, Coordinator, Farmer-to-Farmer Movement, ANAP, interview, 2011).

What Castillo refers to is the recent agrarian reform that began in 2008, whereby unproductive land is being distributed to agricultural producers, and ordinary citizens who want to farm. ${ }^{36}$ The focus of this reform is to substitute importations through local production. Pérez articulates, moreover, that production is dependent upon "political will" and commitment of resources to this end. As I demonstrate below, at the campesino level, such commitment is an area of contested terrain, despite government plans to restructure access to agricultural inputs. ${ }^{37}$

\subsection{Livelihood}

Professional interests that relate to population needs, conserving farm biodiversity, and national security dominate the discussion regarding food security; yet, the majority of campesinos in my sample consider the security that diversity affords in terms of personal needs. What I mean, is emergent within discussions of what crops campesinos produce and their reasons for producing

\footnotetext{
${ }^{36}$ Originally the state was giving 13.42 hectares of land in usufruct; but, apparently, since 2010, the state will give more land to farmers that turn a good yield and profit (Gonzalez, Mentor/Professor, Marxism Department, UNISS, conversation, 2011).

${ }^{37}$ Lineamento 182 (the lineamentos are guidelines for country projections outlined during the $6^{\text {th }}$ Congress of the Cuban Communist Party in 2011), for instance, reads as follows: "Restructure the current system for the sale of agricultural inputs and equipment, considering the new food production scenario and the financial mechanisms to be established, assuring an appropriate correspondence between quality and prices of the products on sale. Facilitate the direct access of productive entities to these resources through the network of stores that will be set up in municipalities" (Cameron, 2011).
} 
such crops are themes of family consumption and economic sustainability. The following excerpts, for example, are representative of how several campesinos responded when asked, "What crops do you produce and why?"

PRODUCER 9: From the economic point of view, tobacco is the most important. FARM MANAGER: 2 hectares of tobacco. We produce to sell to the state and to the enterprises of the state-- tobacco and other crops. We make a contract to sell the other products, for example, beans, banana, taro, yucca, sweet potato, milk. Tomato is for our own consumption, we don't sell it. When we don't sell to the state, we sell to the citizens at the feria [local agricultural market]....

PRODUCER 9: 2 horses, chickens, pigs... not to sell but only to eat here (interview, 2011).

These participants refer to the contract system that is characteristic of Credit and Service Cooperatives (CCS) described in the introduction to this thesis. Briefly, producers make contracts with the state regarding the crops and the quantity they will produce; once they fulfill the contracts, they are free to sell the remaining produce at agricultural markets according to prices set by supply and demand.

PRODUCER 7: The main mission here is to produce tobacco. If I did not produce tobacco, I would not make enough profit to survive.... The other crops-- grains, vegetables, and root vegetables-- I produce them for the consumption of my family and workers. The price of tobacco is set by the state, so... these other crops could provide extra income, sustenance to the family (interview, 2011).

PRODUCER 8: [Before the Revolution, campesinos] produced tobacco to make money, and the rest of the crops were for family consumption. After the Revolution triumphed, agriculture changed. Crops that campesinos produced for family consumption, the state was in the condition to buy them and distribute [sell] to the population. Crops were converted to marketable products. We could also sell directly to the people, so we diversified-- if one crop failed, the other might produce more and provide economic support (interview, 2011).

Although Producer 8 highlights the agricultural reforms following the Revolution, he still dedicates his farm today to tobacco production; hence, the common thread between each of the above responses is that tobacco is the main crop produced ${ }^{38}$ the motivation for which is income,

\footnotetext{
${ }^{38}$ It is important to note that Cabaiguán is a municipality that specializes in the production of tobacco; farmers in this region typically note that they produce tobacco as a "duty" to the state.
} 
and that the remaining crops supplement the families' food and monetary resources. In this way, diversity is seen as providing personal, not national, economic security.

For campesinos, as distinct from professionals then, the capacity to produce is bound to their livelihood. It follows that campesinos typically consider food security in individualistic terms that revolve around their personal ability to produce. According to the following producerparticipants, for example, food security is:

Related to apply the right technology to be sure that we [producers] are able and I am able to produce food, get good results (Producer 1, interview, 2011).

The production-- that I am able to produce is very important for my family and that I am able to produce for the people [the Cuban population]; to ensure the food supply of the people... (Producer 4, interview, 2011).

Food security is to be able to plant, and to grow food for my family, and to have food kept in my house for a full year (Producer 10, interview, 2011).

These campesinos highlight the appropriate application of knowledge, skills, technologies and practices to obtain a good yield. However, implicit within the emphasis on "being able" is the reality that for campesinos, their ability to produce is intimately tied to their access to agricultural resources and inputs; such access, as they see it, is highly constricted and complicated by the minimal availability of state-sanctioned resources.

In order to cope with restrictions to agricultural inputs, producers tend to stretch resources administered by the state as far as they will go, and when possible, purchase chemical inputs on the black market. As I mentioned, cultivos potenciados (enhanced or prioritized crops), such as onions, or crops that are integral to the Cuban economy like tobacco, receive statesupport in the form of technological packages; it is these crops that provide producers with income, but equally importantly, with chemical inputs. As this campesino, somewhat frustratingly remarks, "If you don't produce tobacco, you don't receive anything" (Producer 10, 
interview, 2011). This producer alludes to a practice I observed in 10 of the 12 campesinos interviewed. Campesinos use the chemical inputs that come in technological packages to first treat and fertilize the priority crop, such as onions or tobacco, and then use the remaining chemical inputs in other crops. Most consider that if the remaining crops are not treated with some chemical inputs, they will not produce a high yield. In terms of resource limitations, Producer 4 asserts:

The farmers are the ones who produce food in Cuba. All the [state] enterprises that produce food have disappeared. Cultivos Varios Banao [Various Crops Banao] was an important [state] enterprise that disappeared. They [the state] do not plant anything-- if the state is the one who has all the resources but does not produce any food, how can the economy improve? The weight of all the food in Cuba lies on the farmers with that little bit of resources (interview, 2011).

Both this testimony and Producer 10's contention that the state would not support him with agricultural inputs unless he produces tobacco, exemplify that the incumbent responsibility to produce gives rise to state-resistance. Such resistance manifests itself in the continued use, and in some cases over-use, of chemical products. Again, as Producer 4 notes, "I used 800 liters of fuel in my last harvest. Do you know how much the cooperative ${ }^{39}$ provided? 20 liters. We are doing things with great effort" (interview, 2011). In this sense, then, it seems that the internalization of the capacity to produce is a contributing factor to chemical-dependency among Cuban farmers.

\subsection{Conclusion}

From the professional perspective, the discourse of food security essentially hinges on farm biodiversity; in this way, intercropping not only ensures that crop diversity can fulfill population needs, but also establishes ecological and national security. The emphasis on national security makes sense given the current focus on reducing reliance on external support by simultaneously decreasing imports and expanding small-scale, ecological agriculture. Importantly, the large-

\footnotetext{
${ }^{39}$ The state administers agricultural inputs to the cooperatives, which then administers portions to each member farm.
} 
scale transition to agro-ecology is being touted as a success of socialism itself (Premat 2009: 49). According to state and professional actors, the implementation of agro-ecology has had a significant impact. For instance, Gonzalez (Mentor/Professor, Marxism Department, UNISS) states:

The economy and production in Cuba is actually increasing, and in my opinion, rapidly. But just as the economy is increasing, imports are decreasing and this is why people think they are in the same situation-- they don't see the difference. Imports have diminished by $20 \%$ in a year and a half; the production of milk, rice and beans is increasing (Palenzuela interview, 2011).

Essentially, Gonzalez says that imports are decreasing, but that this decrease creates a balancing effect, whereby from the local perspective, people are not aware of economic growth and increasing agricultural production.

Gonzalez's insight is apt in that it provides a context for understanding campesino resistance. Indeed, many of the campesinos in my sample did not consider that the Cuban economy is improving, and there is frustration on the emphasis of agro-ecological approaches to agriculture that revolve around small-scale, low-input practices. For campesinos, food security is bound to their livelihood, and as such, identity. What I mean is that the pressure to produce is not solely tied to economic gain, but also to the performance, skills and knowledge that become the emblems of being a good farmer. Castillo (Coordinator, Farmer-to-Farmer Movement, ANAP), for instance, poignantly remarks: "Farmers cannot lose their yield-- if they lose the harvest, and their family cannot eat, they will be judged by society and fellow farmers" (interview, 2011). In this sense, the state's restriction of resources is considered for some as impeding their "farmerhood" (in other words, their capacity to produce high yields). This internalization of the capacity to produce, then, helps to contextualize both farmer resistance, and chemical-dependency. In the 
following chapter, I further explore the complexities of campesino resistance, which is not only discursively apparent, but also materially evident in farm-spaces. 


\section{Chapter 5: Lived Dimensions of the Agro-ecological Agenda}

\subsection{Introduction}

During field visits, it was apparent that campesinos construct their respective farm-spaces ${ }^{40}$ both materially and discursively, in unique ways; however, there are also many congruencies between spaces. Clearly, such congruencies are due in part to the fact that producers have similar access to seeds, agricultural inputs, and information. Also, there are traditional, local, geographical and climatic factors that lead campesinos to produce similar crops, using similar practices. For example, campesinos often credited tradition as a motivation for producing onions and tobacco, in Banao and Cabaiguán, respectively. However, similarities between farm-spaces are also representative of the professional and state influence upon and governance of agricultural practice. Such consistencies are indicative of what Lefebvre deems "representations of space," or more simply "conceived space" (Lefebvre 2000: 38; Premat 2009: 30). Premat explains that conceived space "is associated with the totalizing and idealized visions that decision makers and people in position [sic] of authority, consciously or otherwise, attempt to inscribe in space" (Ibid.). On the other hand, Lefebvre (2000: 42) writes that "representational space is alive: it speaks." In this way, representational space is construed as "lived space," which "is linked to the inhabitants and users of space who can use their imagination to appropriate and change 'dominant space"' (Premat 2009: 30). Thus, the aim of this chapter is to explore the interplay between the conceived and the lived dimensions of agricultural space. ${ }^{41}$ In other words, how do campesinos interpret and materially enact the promotion of ecological agriculture by the Cuban

\footnotetext{
${ }^{40}$ By space, I am referring to the physical landscape of farms, and the material entities within those landscapes. However, my conception of space follows from that of Henri Lefebvre, where the material (what he calls "spatial practice" or "perceived space"), the ideational ("representations of space" or "conceived space"), and the social aspects of space ("representational spaces" or "lived space") are inevitably intertwined.

${ }^{41}$ The idea to examine the interplay between the conceived and lived dimensions of space has been adapted from Adriana Premat's article entitled, "State Power, Private Plots and the Greening of Havana's Urban Agriculture Movement." Premat (2009: 28) "applies Henri Lefebvre's insights on the social production of space to the processes
} 
state and professionals?

Tied to the interplay between conceived and lived space are various discourses that professionals use to categorize producers. Sections 5.2 to 5.4 of this chapter explore three of these discourses: promoters (los promotores), agriculturalists, and agro-ecological versus agrochemical campesinos. Although these categorizations are readily subscribed to, and reproduced in practice by some campesinos, others exhibit some level of resistance. Farmers do express resistance discursively, but this chapter exclusively examines how resistance is materially manifest. Concurrent with Lefebvre's understanding of the lived dimensions of space that can serve to destabilize "dominant space," the lived farm-spaces of campesinos can exemplify resistance (Premat 2009: 30). Here my understanding of resistance stems from Foucault (1994: 137), for whom "power" is exercised in a relational context; though he also states:

The exercise of power is not simply a relationship between 'partners,' individual or collective; it is a way in which some act on others. Which is to say of course that there is no such entity as power... Power exists only as exercised by some on others, only when it is put into action, even though, of course, it is inscribed in a field of sparse available possibilities underpinned by permanent structures.

In this sense, then, campesino resistance (power) is manifested in certain acts and practices that run counter to the agro-ecological agenda. In some cases, such resistance is bound to local and traditional agricultural knowledge that conflicts with scientific knowledge around appropriate ecological practices. Therefore, the ways in which producers construct their farm-spaces works to both confirm and to complicate professional typologies. As such, farm-spaces can convey the reductionist nature of the discursive constructs around agro-ecology.

\subsection{Los Promotores}

Alongside the national goal of developing ecological agriculture, scientists and agricultural 
extension workers express discourses regarding ideal producers. Value that is attributed to agroecological practices is, moreover, embedded within these discourses. When I asked Castillo (Coordinator, Farmer-to-Farmer movement, ANAP) how many producers in Sancti Spiritus are agro-ecological, she explained:

[There are roughly] 36,000 [CCS and CPA] farmers in Sancti Spiritus, and all of them practice agro-ecological techniques in a conscious way. But those who are passionate about their work, and love nature, there are about 1000 farmers-- promoters, men and women, that know what they have to produce and why they have to produce that way. They use these techniques at a high level and are transmitting this knowledge to the new generation (interview, 2011).

Castillo refers to the institutionalization of producer types, in the sense that extension services, such as ANAP and ACTAF distribute certain certificates and titles for producers who are "true" agro-ecologists. ${ }^{42}$ For Castillo, integral to retaining the title of ecological producer is a commitment to the extensive use of sustainable practices, and a personal affinity for nature. Moreover, ANAP endorses agro-ecology through the work of promoters (los promotores). Promoters are characterized as producers that embody the agro-ecological agenda through not only the full adoption of sustainability as a way of life, but also a socialist commitment that revolves around communitarian ideals of teaching, sharing knowledge, and the grassroots mobilization of local producers to adopt agro-ecology (ANAP 2001: 23, 46). As Producer 7 put it, promoters are "the bible of ecology" (interview, 2011). ${ }^{43}$

Promoters represent ideal types of producers partly because of the agricultural practices they employ. Certain practices, then, are also construed as ideal, such as intercropping. As

\footnotetext{
${ }^{42}$ To my understanding, ACTAF administers certificates to farmers who have an exemplar record for following agro-ecological practices; for example, one such certificate is given to farmers who have been agro-ecological for 10 years (Palenzuela, President, ACTAF, interview, 2011). This system of certification and titles was not a focal point of this thesis; it merely emerged during interviews. Thus, this discussion does not include a full representation of the certificates and titles administered by agricultural extension services.

${ }^{43}$ In the case of ANAP, their Farmer-to-Farmer movement relies upon a "horizontal methodology of knowledge exchange" (Nelson, in conversation, 2011). Such horizontality is construed as a means to circumvent top-down power dynamics (ibid.). The promoters and the ways in which they use their farm-spaces as teaching tools, then, are integral to this methodology.
} 
discussed in Chapter 4, intercropping is associated with the professional emphasis on farm biodiversity. Thus, the ultimate ideal is a campesino who fully exploits the possibilities to create biodiversity in their farm-space. The producers in my sample all employ varying practices that contribute to biodiversity; however, the farm-spaces of the two ANAP promoters exhibit a higher degree of diversity in a number of observable ways. Promoter A, for instance, makes extensive use of floral trees as living barriers [see Figure 5.1: Living Barrier-- floral trees (Promoter A) and Figure 5.2: Living Barrier-- floral trees, other plants and shrubs (Promoter A)]. Figure 5.1 shows a large wall of floral trees, while Figure 5.2 shows floral trees interspersed with other plants, shrubs and trees. Virtually, the whole perimeter of the farm-space is delineated with such barriers; this is the sole farm on which I witnessed the use of flowers to this extent. ${ }^{44}$ Promoter B also makes unique use of diversity practices. Figure 5.3 depicts a rice field surrounded by a manually constructed dike, which is a common practice among campesinos that produce rice. However, unlike other campesinos, Promoter B's dikes also function as living barriers, and, even more uncommon, is the fact that this promoter plants pineapple trees in the barrier [see Figure

\section{4: Pineapple Tree in "Living Barrier" Dike (Promoter B)]. The farm-spaces of ANAP} promoters, then, not only materially manifest the professionals' discursive emphasis on farm biodiversity; they also represent ideal sites of agro-ecology. In this way, promoters' lived space is consistent with what agricultural professionals conceive of what agro-ecological farm-spaces should be.

\subsection{Agriculture}

Promoters represent an ideal type of producer, whereby their unique practices and farm-spaces reproduce agricultural professionals' idealized visions of agro-ecology.

\footnotetext{
${ }^{44}$ It is important to note that this practice is not unique in Cuba, and that many campesinos employ the use of floral trees for agro-ecological purposes. However, this promoter represents the full exploitation of this practice, and this sets him apart.
} 
Figure 5.1: Living Barrier-- floral trees (Promoter A)

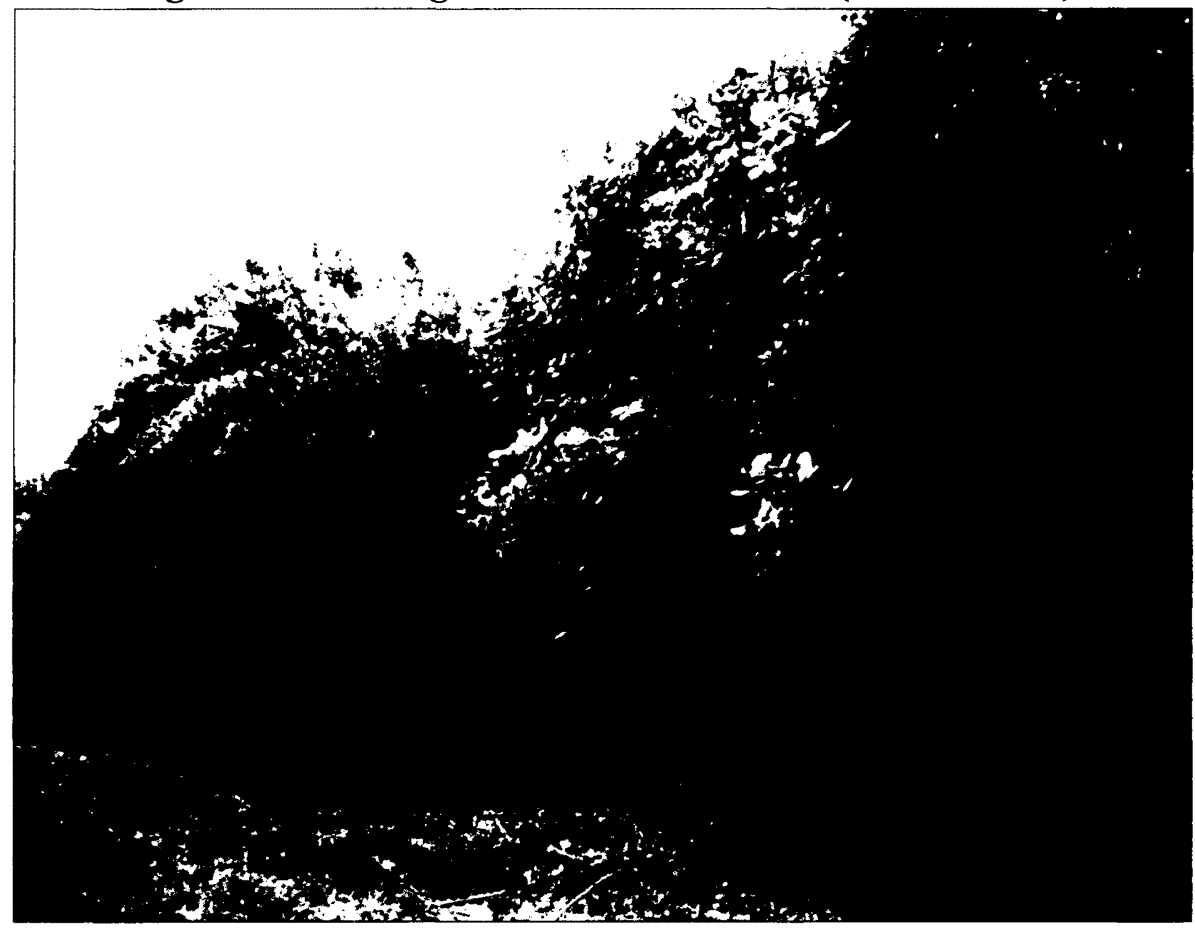

Figure 5.2: Living Barrier-- floral trees, other plants and shrubs (Promoter A)

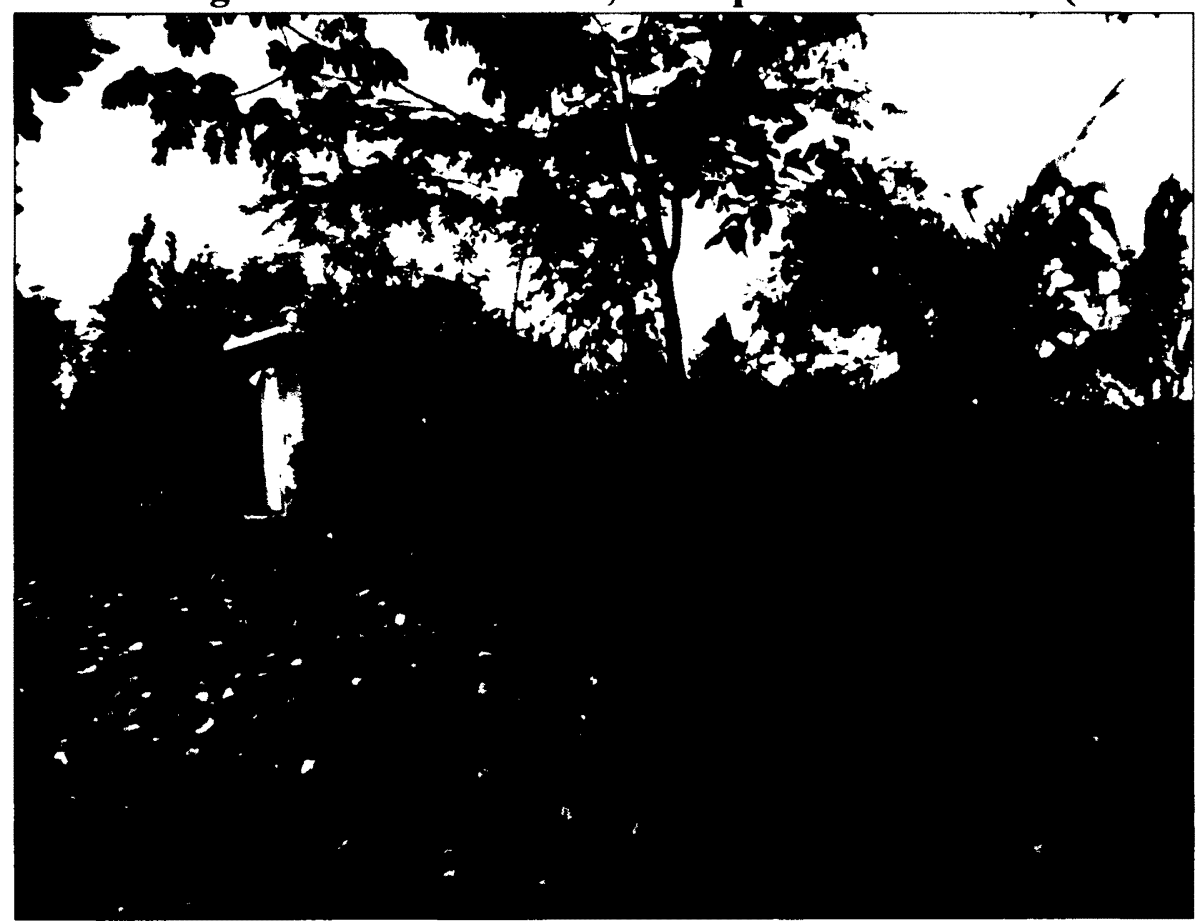


Figure 5.3: Rice Field surrounded by a "Living Barrier" Dike (Promoter B)

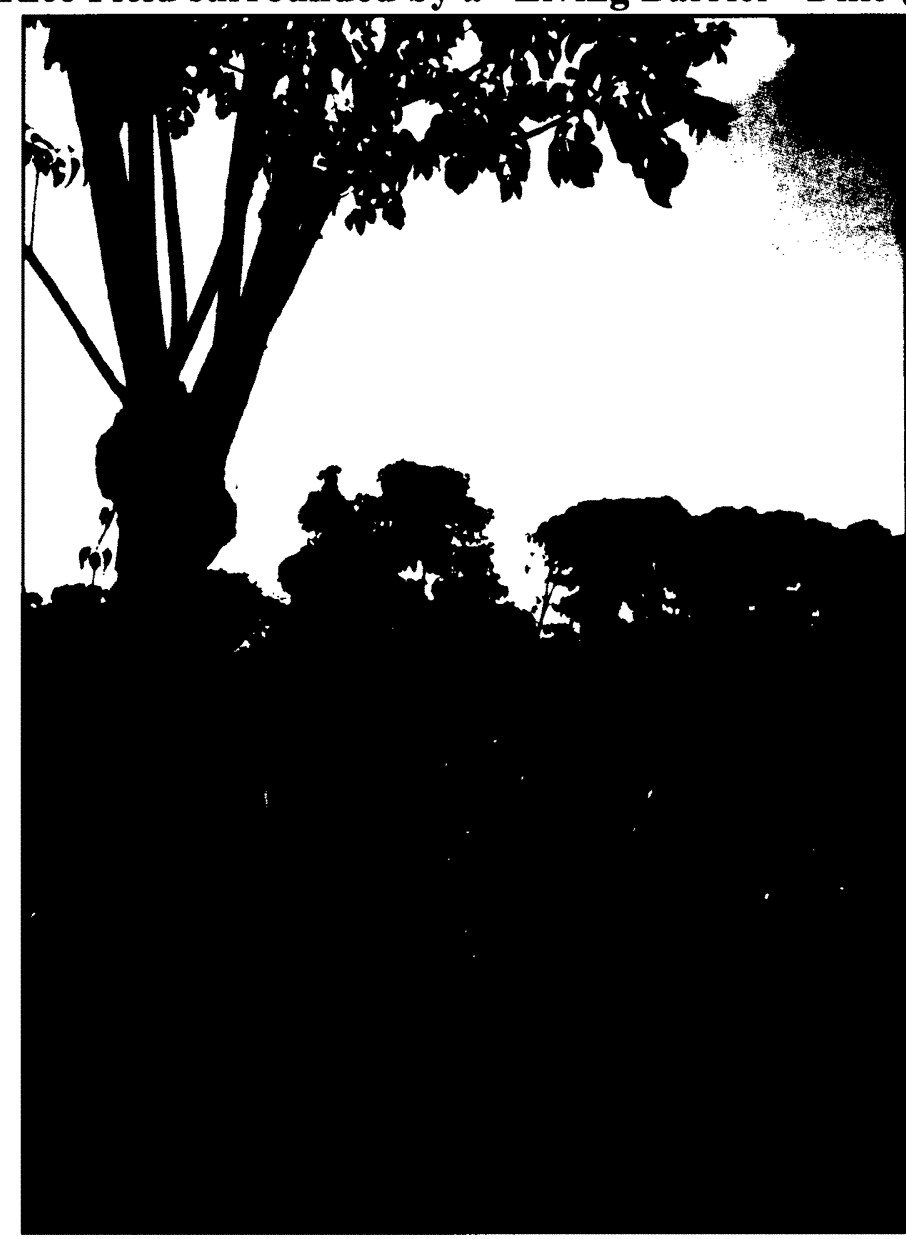

Figure 5.4: Pineapple Tree in "Living Barrier" Dike (Promoter B)

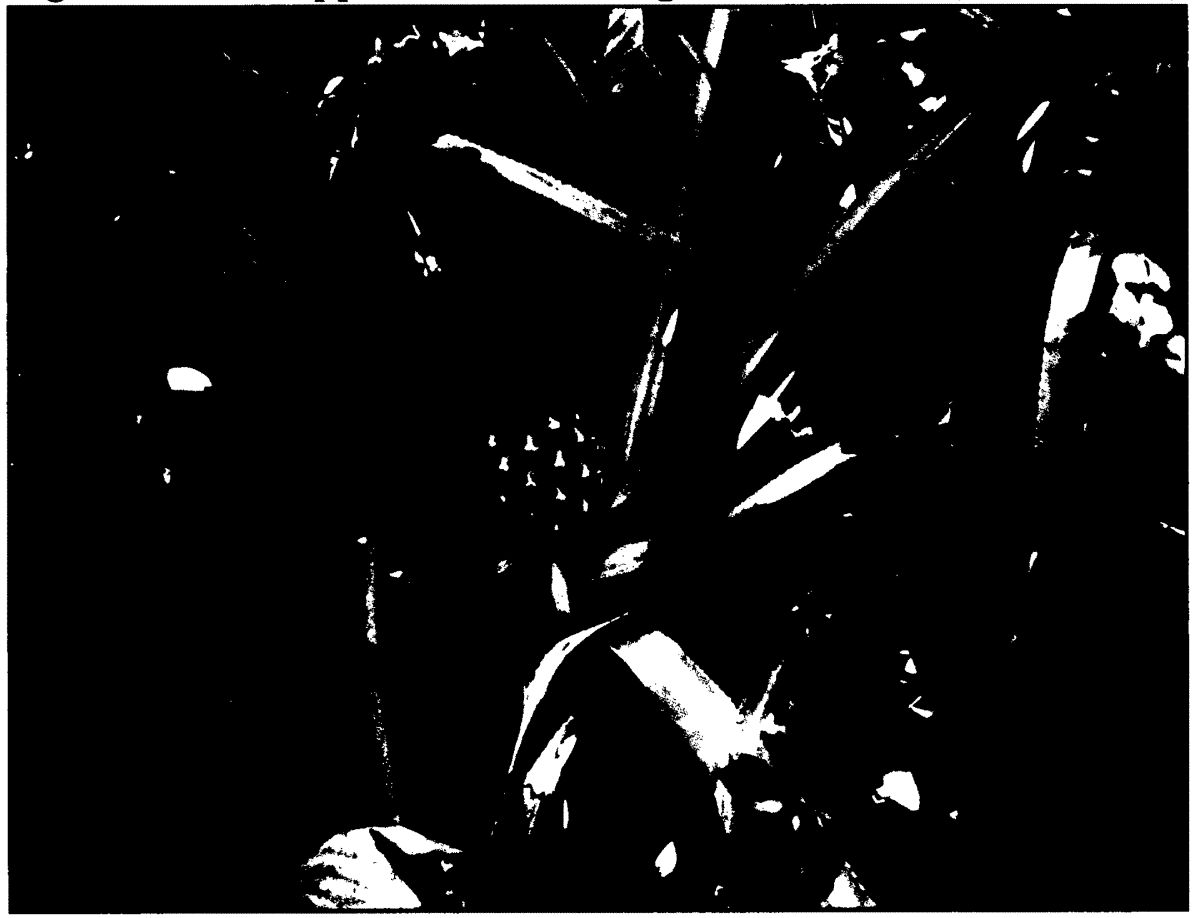


Embedded within such ideals is a complex discourse regarding the culture of agriculture. What I mean is that agricultural extension workers, and other agricultural professionals, express a positive bias towards producers that live and work according to a farmer culture, referred to here as agriculturalists. Agriculturalists are held at a higher esteem than those producers characterized as "businessmen" that professionals consider as simply profit driven. Given the entrenched tradition of chemical use in Cuba, and the common perception among producers that chemical use ensures high crop productivity, the profit motives of these "businessmen" make them a particular threat to agro-ecology (I will revisit this discourse in the conclusion of this thesis). The agriculturalist discourse is primarily tied to generational producers who retain some traditional agricultural knowledge and culture ${ }^{45}$; also, it is deeply connected to a broader discourse around innovation and material scarcity that is the corollary of the economic collapse of 1989. In response to this collapse, the Cuban government "encouraged a massive conversion of agricultural production towards a scaled-down, green approach associated with self-reliant, sustainable and organic practices on small production units" (Premat 2009: 32). Linked to this scaled-down agriculture was the Cuban government's "official message... that citizens could no longer expect the state to provide; now citizens had to help themselves by 'relying on their own efforts and means"' (Castro in Premat 2009: 34). As noted above, then, ANAP promoters epitomize this idea of self-reliance: they interpret and employ the practices of farm biodiversity in unique ways, and they innovatively make use of resources at hand. Such innovation, and the ability to experiment, is an essential component of who is considered an agriculturalist.

While most promoters would likely fall within the agriculturalist typology, not all agriculturalists are promoters. Like promoters, agriculturalists confirm professional ideals of

\footnotetext{
${ }^{45}$ The emphasis on traditional agricultural knowledge has been enveloped within the agro-ecological movement because traditional practices, such as animal traction and intercropping, were revitalized as sustainable means to dealing with post-Soviet conditions of material scarcity (Funes et al. 2002).
} 
agro-ecology with their practices and farm-spaces. Discussing post-Soviet conditions, and the state emphasis on self-reliance, one producer explained, "We became artists" (Producer 10, interview, 2011). Indeed, during farm visits I was able to observe which producers could be characterized as artists of innovation. A remarkable example of such artistry is the farm-space of a producer who has molded and remolded the landscape of his farm in order to prevent against the effects of erosion [see Figure 5.5: Royal Palm tree trunks embedded in terrain to prevent erosion and Figure 5.6: Grass Thoroughfare-- banana (left) and papaya (right) plantations]. Figure 5.5 shows the trunks of 2 royal palms (palma real) embedded within the terrain in order to prevent soil from washing away down slope; Figure 5.6 depicts a banana plantation on the left, a papaya plantation on the right, and a grass thoroughfare running in between. The purpose of the thoroughfare is twofold: first, it allows the passage of tractors between fields; second, the terrain is built up and prevents the soil from, again, washing away down slope. Agricultural innovation entails the ability to make use of not only scientific agro-ecological knowledge, but also repositories of traditional agricultural and local farmer knowledge. ${ }^{46}$ The farm-space featured in Figures 5.5 and 5.6, then, is innovative because the campesino has addressed agro-ecological concerns over erosion by using local materials that are free and close at hand.

However, practices that develop out of traditional and local agricultural knowledge can also be points of contestation. Within the context of multiple knowledges, scientific and traditional, a contradiction within the agriculturalist discourse emerges. In other words, there is a fine line between innovation and resistance.

\footnotetext{
${ }^{46}$ For the purposes of this thesis, traditional agricultural knowledge is akin to traditional environmental knowledge but restricted to agricultural practices; moreover, traditional agricultural knowledge encapsulates knowledge and practices that persist for generations, but also knowledge that is derived from empiricism (as opposed to professional or scientific knowledge, as I explained in the methodology section of this thesis).
} 
Figure 5.5: Royal Palm tree trunks embedded in terrain to prevent erosion

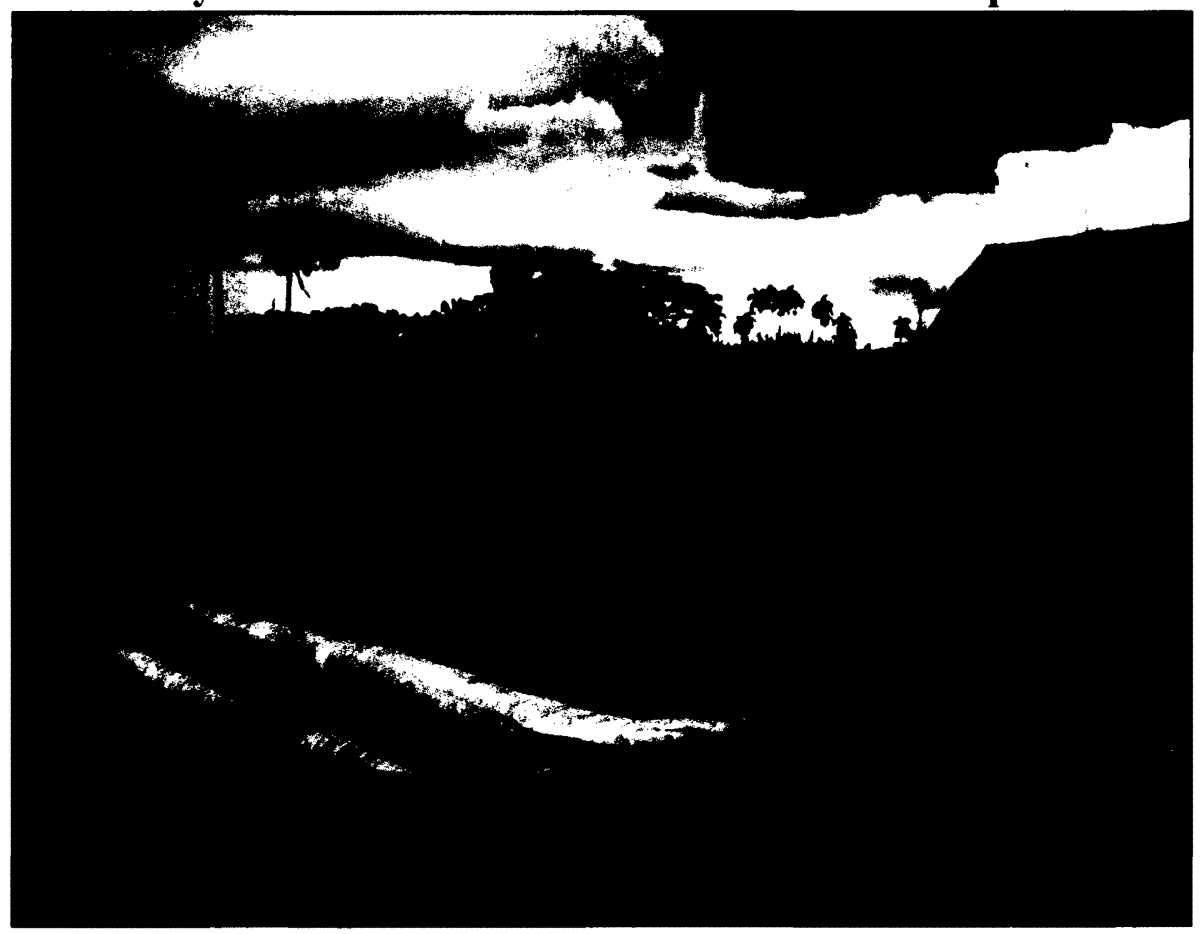

Figure 5.6: Grass Thoroughfare-- banana (left) and papaya (right) plantations

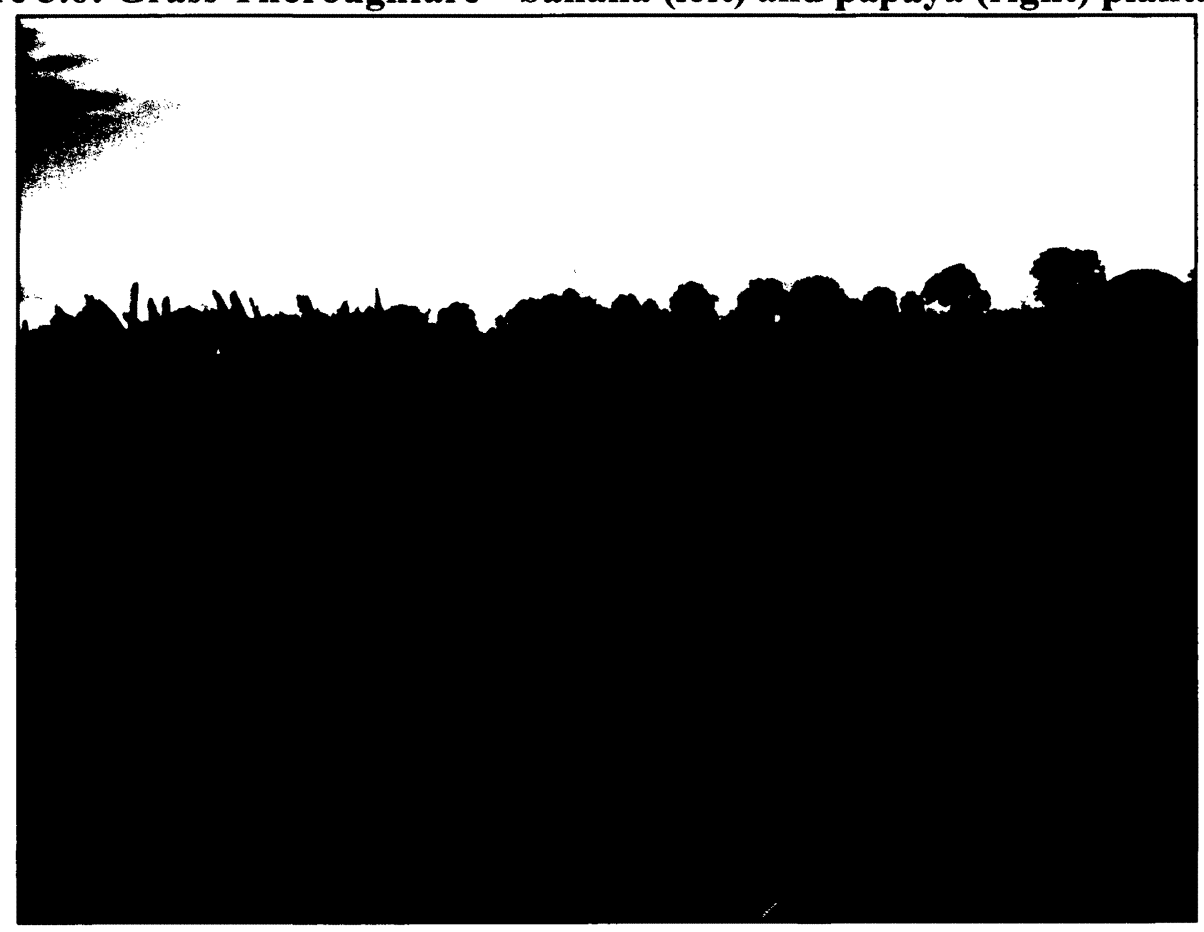


As Foucault (1980: 142) argues, "there are no relations of power without resistances; the latter are all the more real and effective because they are formed right at the point where relations of power are exercised.... [L]ike power, resistance is multiple." Thus, power and resistance are exercised through the adoption or rejection of different knowledges, and corresponding material practices. Although a key feature of the agriculturalist discourse revolves around the ability to experiment, experimentation is only ideal if it serves to further the agro-ecological agenda. The practices of a producer in Banao illustrate how local farmer knowledge can detract from this agenda. For instance, this producer intercrops onions, tomatoes and papaya: in the same space, he plants onions in September, followed by papaya in October. He harvests the onions in December then plants tomatoes, which are typically mature by May. Finally, between the months of August to December (the following year), he harvests the papaya. The following discussion between two CNSV professionals demonstrates how this producer's practice challenges state recommendations regarding plant protection:

AYALA: This is not in the recommendation of CNSV because tomato is attacked by whitefly and papaya is attacked by whitefly... whitefly transmit some virus. GOMEZ: A good farmer has the initiative to make experimentation, to do the trial [of what works and doesn't work].

AYALA: He [the producer] is telling the history of when he made a contract with a seed enterprise to produce papaya seeds, and when the inspector came to see the field, [the producer] had planted tomatoes between the rows of papaya. The inspector said it was prohibited due to the problem of whitefly, but [the producer] said it is not a problem if you pay attention to the crop, and he produced more than 100 quintals ${ }^{47}$ of tomato, and more than 300 quintals of papaya to get the seeds. The enterprise said that he was one of the largest producers of seeds in spite of the small size of the production area (Producer 1, interview, 2011).

This excerpt exemplifies the power dynamics and interplay between scientific knowledge, as subscribed to by the state enterprise, and local farmer knowledge. But it also shows the personal interests of each actor: Ayala (primary translator/Biocontrol Specialist, CNSV) is concerned with

${ }^{47} 1$ quintal is equal to 100 kilograms. 
the unsanctioned combination of tomato and papaya; Gomez (Institutional Communication, CNSV) is proud of the producer's capacity to experiment; the state enterprise is initially discontented by the unsanctioned intercrop, but eventually content with the high level of production; for the producer, the experience is a testament to the fact that his knowledge results in high yields.

Although this particular producer is not overtly resisting the state or scientific knowledge, some campesinos do. One of the more explicit examples of such resistance is from a producer in Cabaiguán, whose farm-space was the only one to retain the spatial dimensions of monoculture [see Figure 5.7: "Monoculture" Corn Field—between grass (front) and palm trees (back)]. Figure 5.7 merely depicts a field of corn but is different from other farm-spaces because here the corn is not interspersed with other crops: it is not used in an intercrop, or as a living barrier. When asked if they use intercropping as a means to foster biodiversity on their farm, the owner (Producer 9) and manager replied:

PRODUCER 9: No, we don't plant beans and corn together; we have liked monoculture from the beginning. FARM MANAGER: We do not like to intercrop. We like monoculture. We prefer to select the soil for this crop or the other. AYALA: There is a high variability in the soil here? FARM MANAGER: No, it is the same. AYALA: Then why you say you select the soil? FARM MANAGER: No, I don't like to mix crops.

In this particular case, these producers have remained committed to a family tradition of agriculture. The farm has been in operation since 1909, and the owner has been working the farm since roughly 1937. In this sense, then, traditional agricultural knowledge, as it is evident in farm-spaces, is a means through which resistance to the agro-ecological paradigm can manifest itself. 


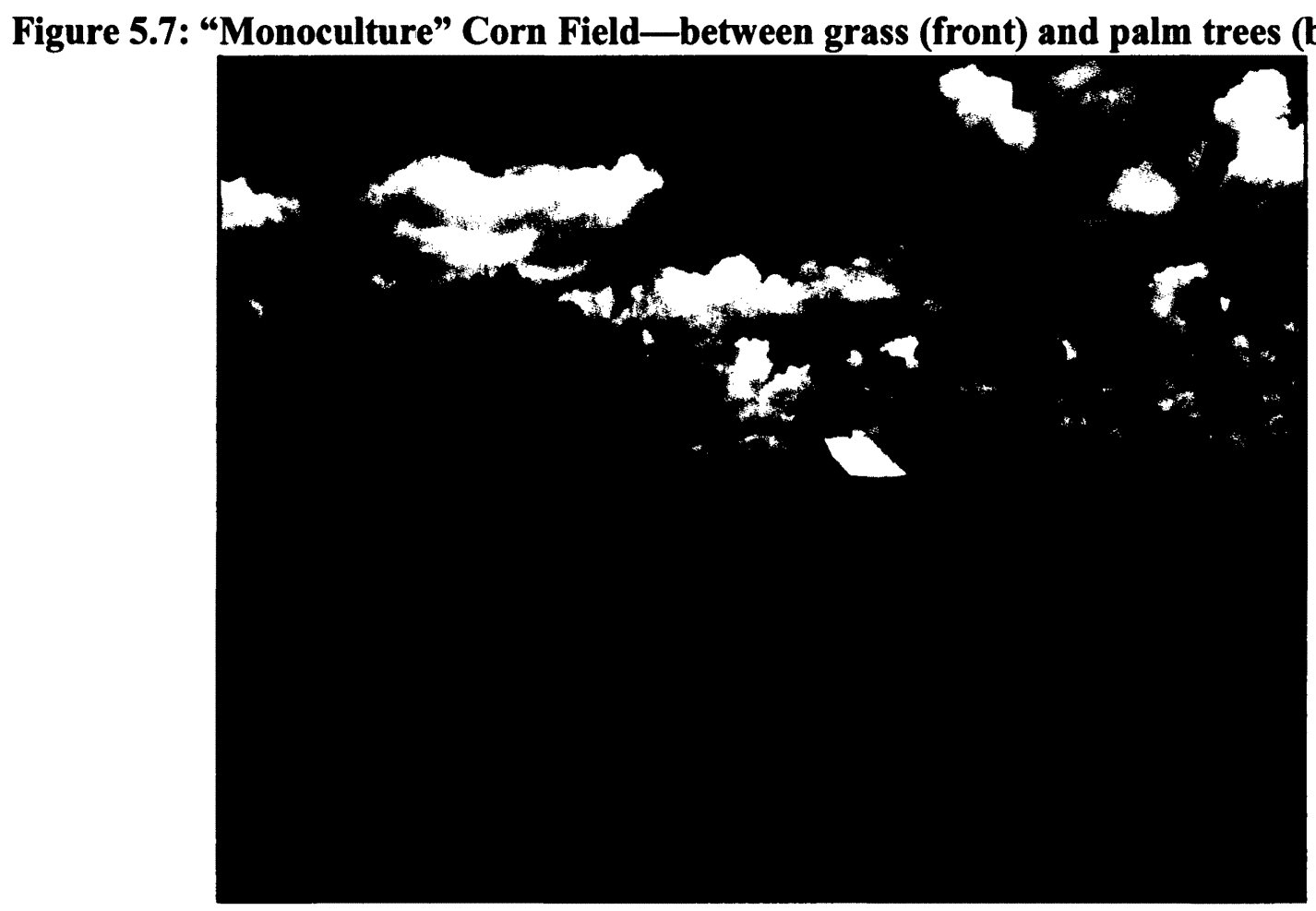

\subsection{Transitional Spaces}

Farm-spaces emerge as material manifestations that support and complicate the agro-ecological ideals propounded by agricultural professionals. Another discourse that professionals subscribe to revolves around categorizing producers as those who prefer agro-ecological or agro-chemical practices. Despite the general consensus among professionals, and producers alike, that Cuba is in the midst of a grand transition toward agro-ecology, the dichotomy between ecological and chemical is still present; it exists because of the persistent chemical dependency among rural campesinos, and the fact that agro-ecology has not been fully integrated into Cuba's agricultural system. What is interesting about the farm-spaces, however, is that some of them challenge this dichotomy. Indeed, the result of some farm tours was that certain producers were "recategorized." For example, a particular campesino in Banao was believed by CNSV professionals to heavily rely upon chemical inputs; his farm-space, though, contrasted with this assumption. 
Figure 5.8: Banana Plants showing damage due to herbicide use

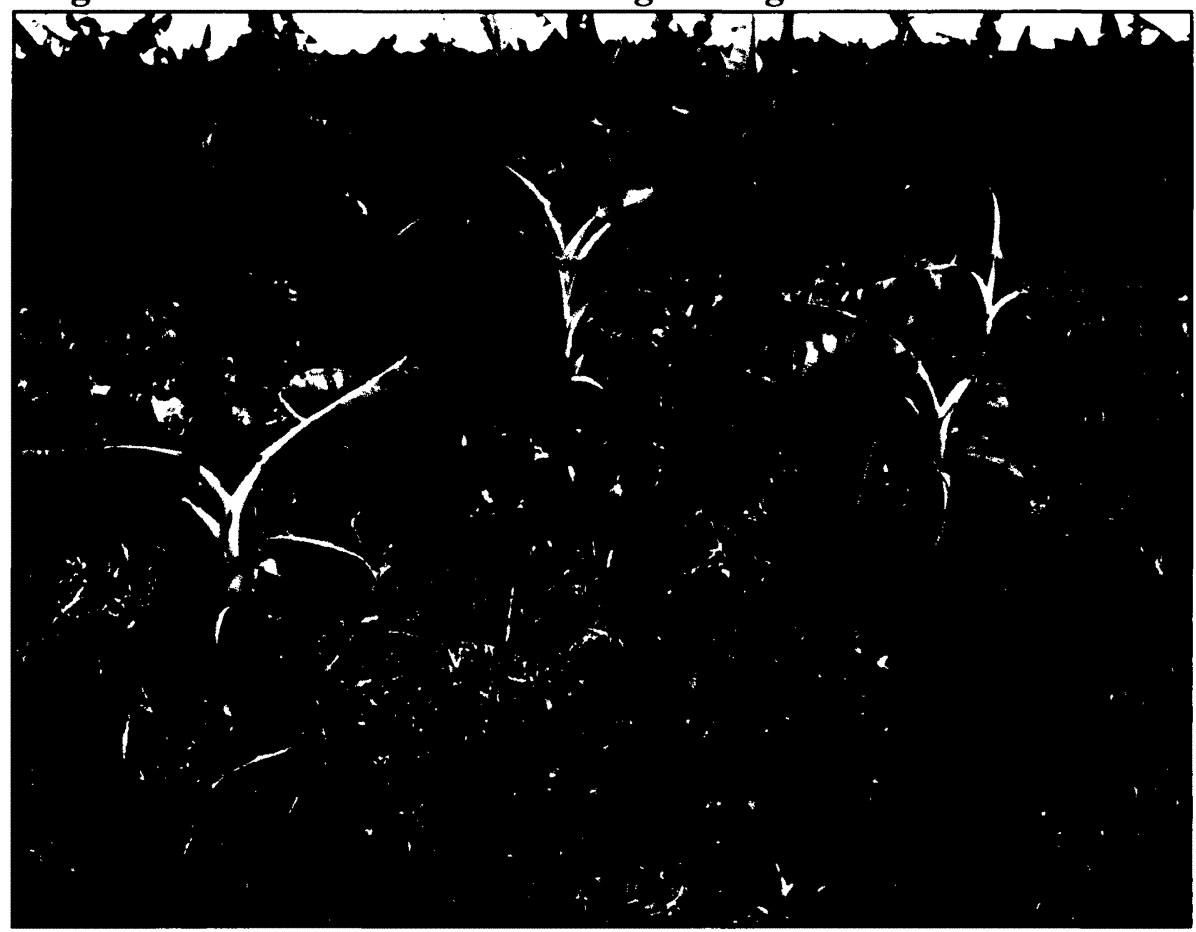

Figure 5.9: Lemon tree leaves showing damage due to fungus (black residue on leaves)

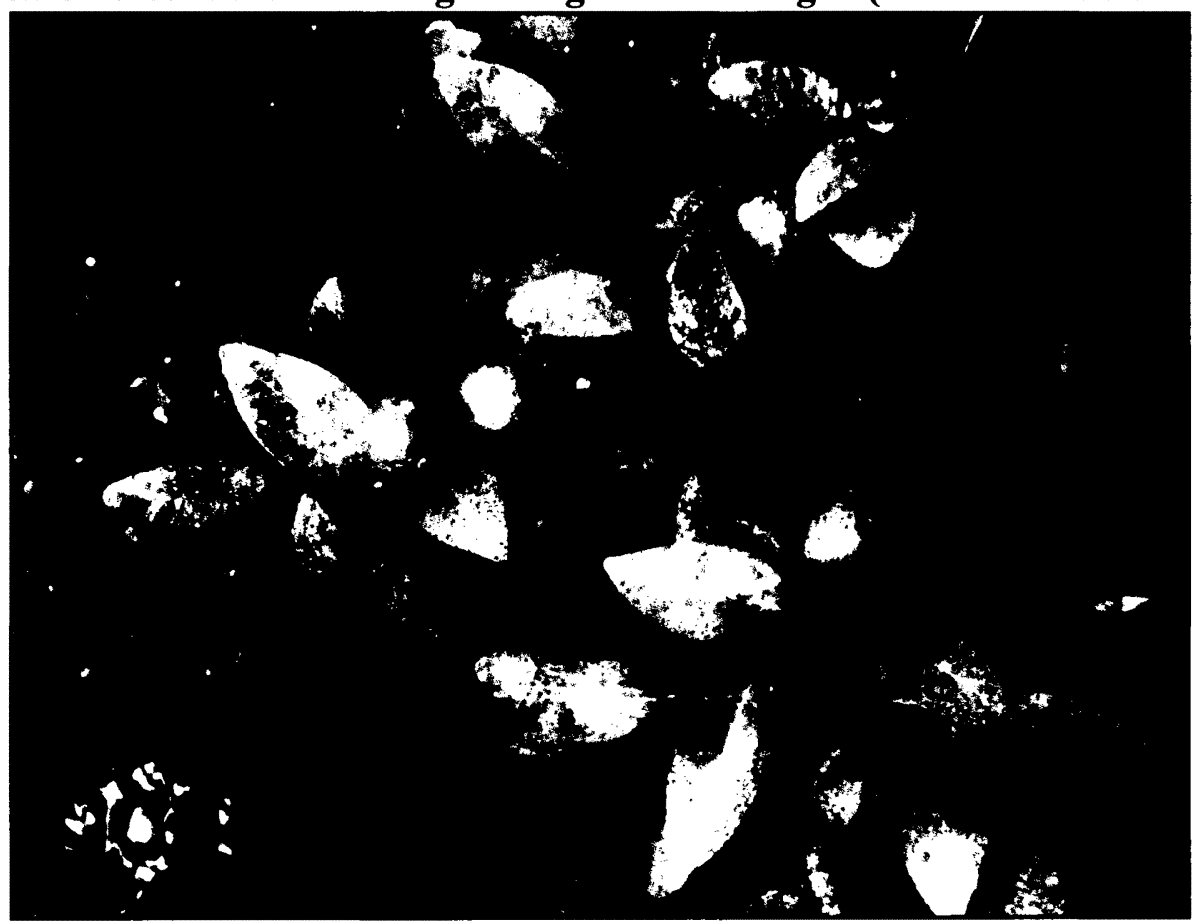


Although I observed one instance where this producer had excessively used herbicide (see Figure 5.8: Banana Plants showing damage due to herbicide use), the space exhibited high levels of intercropping. In addition, this producer had a lemon plantation, which proved unique among the farms that I visited. This plantation was heavily infested with a fungus [see Figure 5.9: Lemon trees showing damage due to fungus (black residue on leaves)], which my primary translator (Primary translator/Biocontrol Specialist, CNSV) took as a sign that this campesino was much less chemical-dependent than anticipated. As this farm illustrates, such spaces function to not only complicate the reductionist nature of the discursive delimitation between agro-ecological and agro-chemical, but they are also a material record of Cuba's agricultural transformation.

\subsection{Conclusion}

Within the emphasis on agro-ecology, professionals express ideals of producer-types and practices. Evidently, such ideals work to construct farmer identities, whereby practices and performances come to be associated with notions of farmer-hood. Discursive constructs that categorize farmers, then, do not exist in a vacuum, and there are material consequences that result from their deployment. Such consequences are also apparent in the farm-spaces that, in turn, function to reproduce, complicate and resist professional ideals of ecological agriculture. Barrett (1991: 135) explains that for Foucault, power is

... something that is exercised rather than possessed; it is not attached to agents and interests but is incorporated in numerous practices. Power can thus work from the 'bottom up', and Foucault uses the notion of the capillary to describe the operations of power at a micro-level. Power is not exclusively negative, either, but produces pleasure and meaning as well as more coercive dimensions.

Indeed, in the interplay between professional and producer interests, and the conceived versus the lived dimensions of space, producer power is construed as "bottom up." Such power is apparent in farm-spaces, which are the product of an intriguing mix of scientific, and traditional 
and local farmer knowledge. It is also worth noting that the farm-spaces of ANAP promoters represent one extreme on a continuum, if you will, that symbolizes the varied commitment on the part of producers to the agro-ecological paradigm. In this sense, I found it difficult to ascertain the difference between campesinos who prefer agro-ecological versus those who prefer agrochemical practices. Hence, "transitional space" is perhaps the most apt way in which to characterize the majority of the farms that I visited. Although this transitional space is a testament to how far Cuban agro-ecology has come, it also represents a certain level of flux wherein not only producers but also the Cuban state is unable to make the transition complete. ${ }^{48}$ As I will explore in the next chapter, this level of flux is further compounded by producer interests that are bound to economic, not solely ecological, sustainability.

\footnotetext{
${ }^{48}$ Please note that my goal is not to represent this inability to completely transition as sinister, but it is simply not possible to grow certain crops without chemical inputs at this current stage in agricultural scientific development.
} 


\section{Chapter 6: Ecology or Economy?}

\subsection{Introduction}

In Cuba, there are a number of political processes that have come to be equated with the development of an ecological consciousness that attributes value to nature among Cuban citizens. These processes range from the influence of national heroes, such as José Martí, associated with Cuban independence (1898), the Cuban Revolution (1959), and continuing agrarian reforms since the beginning of the Special Period (1989). For instance, Martís teachings, which combine the positivistic idea that science leads to nature with spirituality have been appropriated by institutions like the Association of Small Farmers (ANAP) to promote agro-ecological ideals. Also, the Revolution's dismantling of an elite proprietorship in order to redistribute land among citizens and farmers functioned to foster a closer relation between citizens and the land. Finally, the state's emphasis on self-sustenance, and small-scale production as a way to deal with Special Period material constraints has also predicated a valorization of the local; local production systems and knowledge of such systems, then, apparently entail a more intimate relation with nature. Such processes that are seen as engendering an appreciation of nature among Cuban citizens are represented as contributing to the success of Cuba's transition to agro-ecology. Moreover, agricultural professionals maintain that the continued advancement of agro-ecology is dependent upon fostering greater ecological awareness among the public. In this sense, then, discourses around nature and ecological consciousness are predominantly associated with Cuba's agro-ecological paradigm.

To be sure, $100 \%$ of farmers in Sancti Spiritus employ some agro-ecological practices (Castillo, Coordinator, Farmer-to-Farmer Movement, ANAP, interview, 2011). However, when explaining why they use such practices, the dominant discourse subscribed to by campesinos in 
my sample is es economia (it's economy) ${ }^{49}$ Hence, in line with what Gezon and Paulson (2005:

6) refer to as "multiscale frames of reference," this chapter seeks to explore the interplay between state and local processes and actors by first, examining the political processes outlined above; and second, problematizing the predominant association of agro-ecology with notions of nature and ecological consciousness by tapping into the campesino perspective. As such, Section 6.2 proceeds by contextualizing the role that Marti's nature discourse as appropriated by the Association of Small Farmers (ANAP) plays in the agro-ecological movement; and Section 6.3 explores Special Period agrarian reforms that have functioned to frame a localizing discourse of humans in nature. These nature discourses have come to be associated with having an ecological consciousness, and as I will explain in Section 6.4 , such consciousness is tantamount to the advancement of agro-ecology, according to agricultural professionals. Finally, Section 6.5 explores the proverbial other side of the ecological coin: economic and material limitation. Ultimately, in order to integrate the dynamic interplay of "multiscales of reference," agroecology must be understood in both ecological and economic terms.

\subsection{Marti's Nature Discourse}

José Martí was a poet, thinker, and political activist, whose ideas of nature continue to permeate the popular Cuban imaginary. To be sure, Martí fought for Cuban Independence and as such, is an important national hero. Notwithstanding this link to Cuban politics, this discussion is limited to Marti's conceptions of nature as they are tied to the development of ecological values among Cuban citizens. According to Nassif (1994: 6), Marti's beliefs regarding science education illustrate his understanding of nature: Marti's "view of education... [was] based on the study of nature. This promoted social progress, because 'to study the forces of nature and learn to control

\footnotetext{
${ }^{49}$ Farmers use the phrase es economia (it's economy) in reference to being economical-resourceful, efficient, and frugal, not necessarily in terms of the economy.
} 
them is the most direct way of solving social problems' (I, 1076). Science was the only path leading to nature." The notions that science fosters social progress, and that science leads to nature are rooted in the Enlightenment, and positivism $;{ }^{50}$ what is pertinent to this chapter, though, is the idea of going directly to nature, which suggests an intimate relation between humans and nature. Indeed, despite its positivistic foundations, "Marti's naturalism was spiritualized, not biological or materialist" (Ibid.). Martí relates that, "The creation and movement and progress of the earth... is theirs [the people] to cultivate, making it yield by their labours the means of universal well-being and of their own sustenance" (in Nassif 1994: 6). Hence, encompassed in Marti's nature discourse are notions of not only scientific and social progress, but also a spiritual closeness to nature that is aligned to well-being, and selfsustenance.

Marti's nature discourse has been institutionalized by ANAP. When asked what Martí signifies to ANAP, Castillo (Coordinator, Farmer-to-Farmer Movement, ANAP) responded that Marti' "was a politician, and for the Cuban society, our policies are to preserve nature-- it is considered as part of the correct consciousness and wellbeing of humans" (interview, 2011). ANAP's development as an organization resulted from Revolutionary agrarian reforms; this history helps to contextualize what Martí represents to ANAP. For example, Castillo also states that,

Before the Revolution the farmer worked the land and the owner did not. Now people work the land and own it-- they want to be close to nature where there is less contamination [pollution] and more knowledge of plants and animals. Farmers can grow their food and know where it comes from. The origin [of food and all things in nature] is beautiful (conversation, 2011).

\footnotetext{
${ }^{50}$ Positivism here refers to empiricism that rejects metaphysics and theology as seeking knowledge beyond the scope of experience, and holds that experimental investigation and observation are the only sources of substantial knowledge (www.dictionary.com).
} 
Castillo points to the first Revolutionary reform that took place in May 1959; this reform sought to dismantle an elite, and predominantly foreign, proprietorship by expropriating lands, and "limit[ing] the land one person could own to 405 hectares" (Oxfam 2010; Gropas 2006: 254). State farms replaced large plantations, and "the number of small farmers more than tripled (from $45,000$ to 160,000$)$ " (Oxfam 2010). As a result of restructuring land ownership laws, which has been touted as creating a modern peasantry, the Cuban Revolution contributed to the valuation of nature by fostering a sense of proprietorship as linked to working the land (Oxfam 2010). Moreover, many of the small farmers that appeared as a result of the first agrarian reform "became organized as members of the ANAP system of co-operatives" (Gropas 2006: 254). Therefore, Martí is an apt icon for ANAP as he epitomizes both Cuban Independence, and Revolutionary ideals of bringing Cuban citizens back to the land, and to nature (Oxfam 2010). In this regard, ANAP has adopted Marti's writings in their support and guidance of cooperative farmers. For instance, Figure 6.1 below shows two signs depicting the following phrases: Si el hombre sirve, la tierra sirve (If man serves, the land will serve) and La tierra no debe considerarse como propiedad individual (The land should not be considered individual property). These phrases express a nature discourse that revolves around a spiritual closeness to and reliance on the land, in addition to humanistic and communitarian ideals. ${ }^{51}$ Other displays of Marti's writings are on buildings and billboards within rural and farm-spaces [see Figure 6.2: Martí Quote Displayed on opposite side of CCS Cooperative Sign (Banao) and Figure 6.3: Martí Quote Displayed on Home in Cabaiguán]. Figure 6.2 showcases a billboard that says, Quien abona bien su tierra, trabaja menos, tiene tierra para mas tiempo y gana más (Those who fertilize the land well, work less, will have the land for longer, and will gain more). Figure 6.3

\footnotetext{
${ }^{51}$ Notably, the phrase "If man serves, the earth will serve" has become a popularized phrase in Cuba. Indeed, I not only heard producers repeating it, but also observed it painted on organiponico (urban organic garden) sites in Sancti Spiritus.
} 
depicts the following phrase, painted on a person's home: La tierra es la gran madre de la fortuna. Labrarla es ir directo a ella (Earth (the land) is the great Mother of fortune. To till (work) her is to go directly to her). On the opposite side of the billboard in Figure 6.2 is the signage for a CCS cooperative; given that CCSs are affiliates of ANAP, it seems likely that this particular cooperative owner has followed suit with ANAP's adoption of Marti's nature discourse. The Martí quote in Figure 6.3 appears on a person's home, and is not necessarily a marker of ANAP's influence; however, participants emphasized that "Fidel has always loved nature." Evidently, then, Marti's nature discourse is also representative of Fidel Castro's appraisal of nature.

Akin to the discourse of food security that has been mobilized by the Cuban state and professionals to achieve agro-ecological ends (Chapter 4), ANAP's institutionalization of Marti's discourse also feeds into the agro-ecological campaign. Castillo (Coordinator, Farmer-to-Farmer Movement, ANAP) articulates a clear link between Martí and agro-ecology:

[Marti] has always been our guide. He love men, women, children and nature and that is ecology.... Si el hombre sirve, la tierra sirve [If man serves, the earth will serve].... He [man] serves by learning, studying, capacitating, [making] relations with people; he transmits knowledge.... If man thinks in this way, he brings it to the land and the land produces. He plants seeds in the right place at the right time, in harmony with his family [and nature]. That's how he produces (interview, 2011).

Castillo stresses ideals of social progress, and humanitarianism as they are linked to having an intimate relation with nature. But she also asserts: "men, women, children, and nature... that is ecology," which draws a link between communitarianism and agro-ecology, whereby nature plays a role in the "community." In this sense, Castillo highlights the concept of interrelationship, and achieving harmony between humans and nature. 
Figure 6.1: Martí Quotes Displayed at ANAP Headquarters

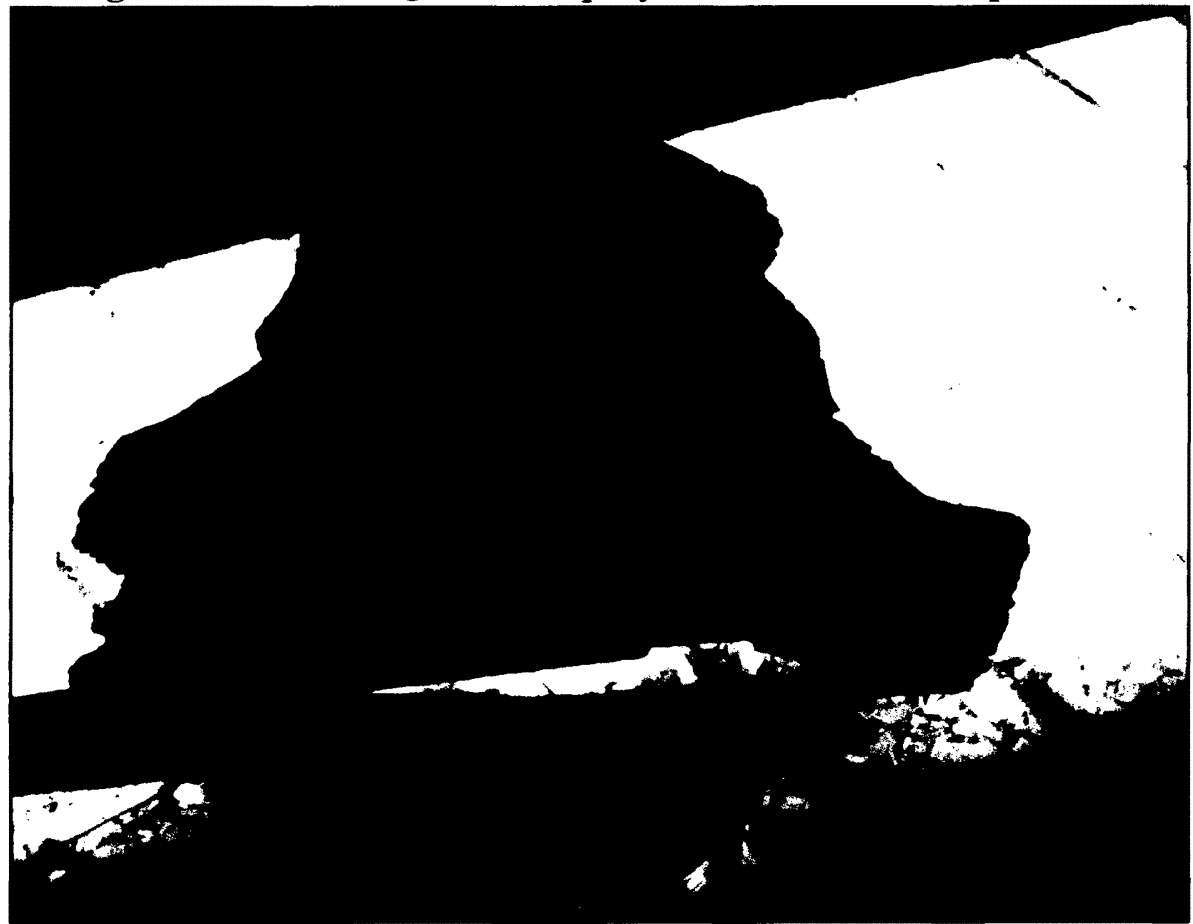

Translation: If man serves, the land will serve.

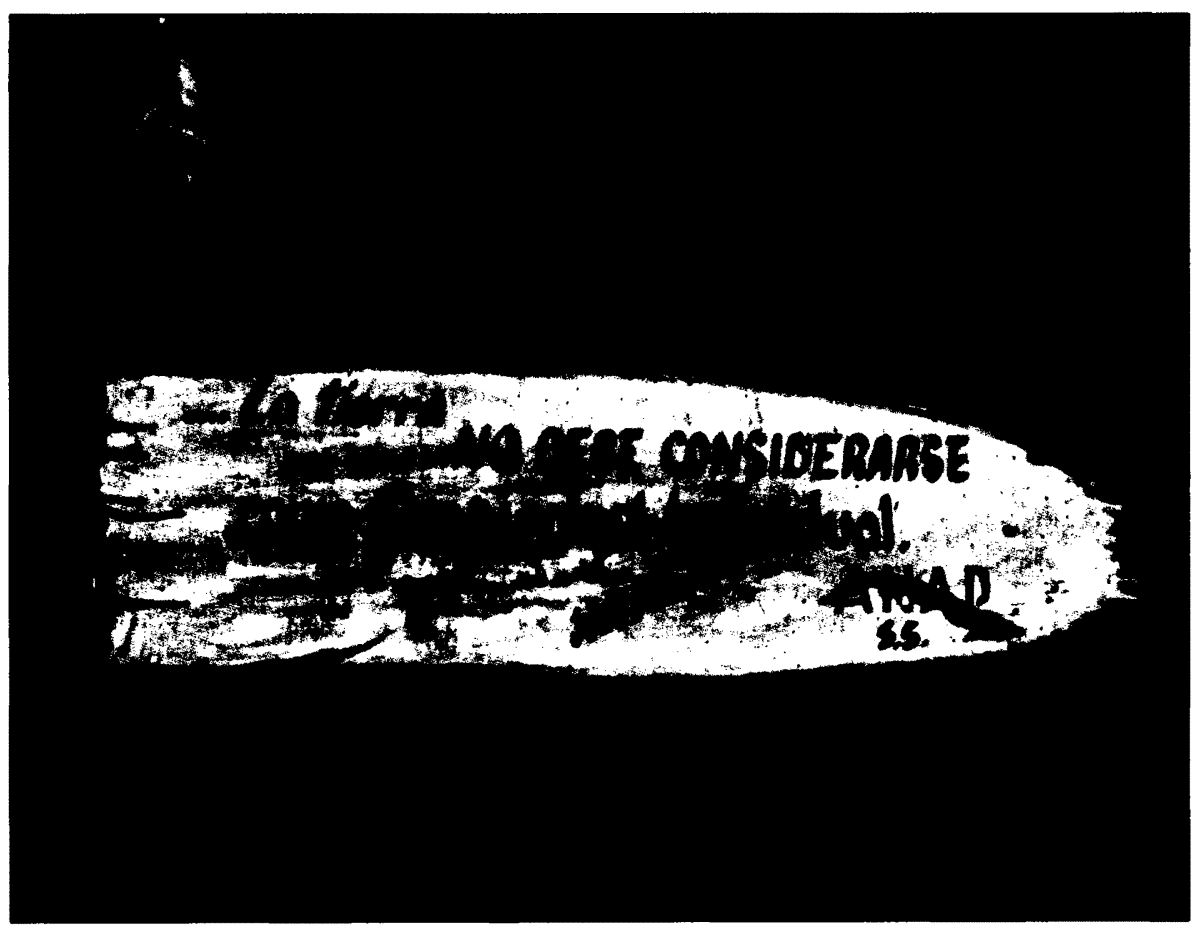

Translation: The land should not be considered individual property. 
Figure 6.2: Martí Quote Displayed on opposite side of CCS Cooperative Sign (Banao)

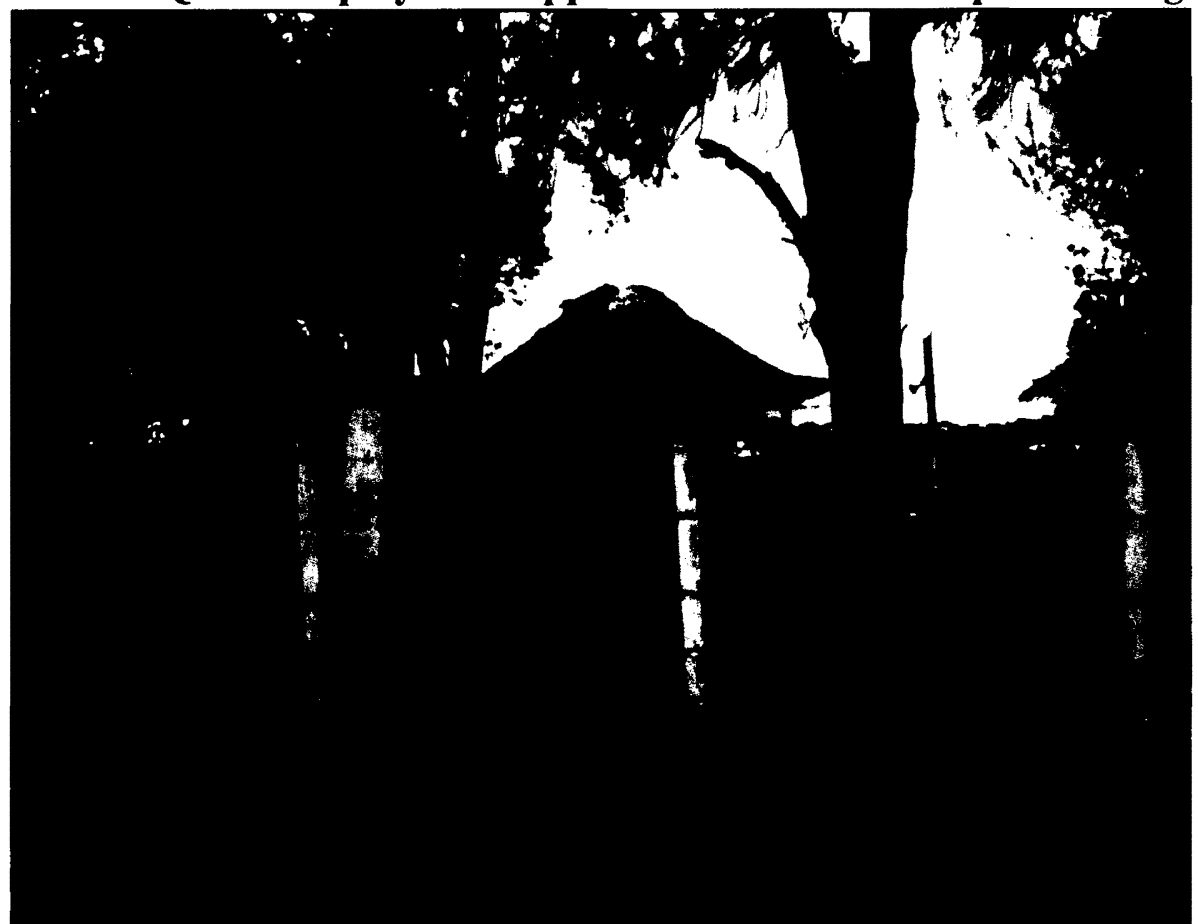

Translation: Those who fertilize the land well, will have the land for longer, and will gain more.

Figure 6.3: Martí Quote Displayed on Home in Cabaiguan

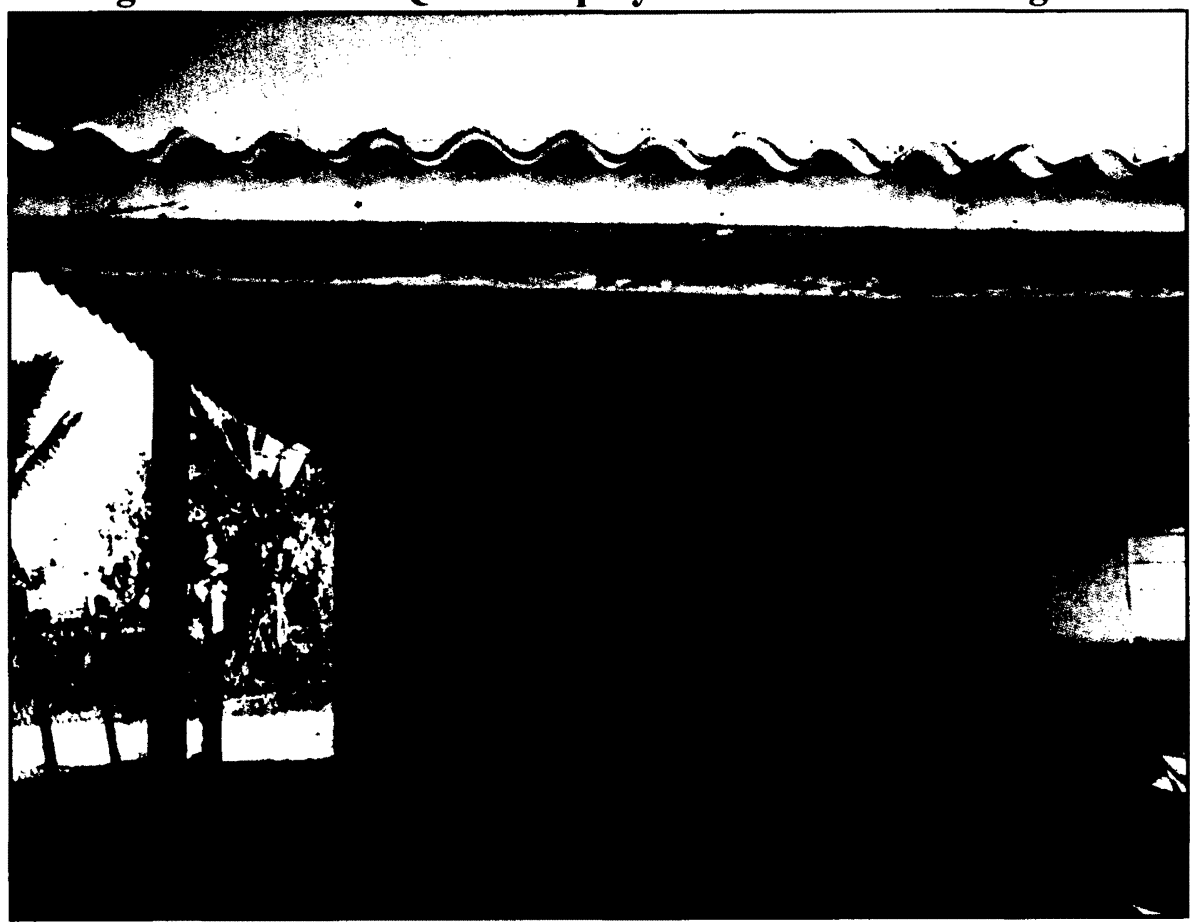

Translation: Earth (the land) is the grand Mother of fortune. To till (work) her is to go directly to her. 
Notably, this harmony is integral to ANAP's vision of what characterizes ecological agriculture.

For example, ANAP endorses certain principles of permaculture. ${ }^{52}$ Take for instance the following testimony by an ANAP Promoter:

Permaculture delineates that all plants and animals are necessary, all have a use, a sense of living, a way of coexisting; in the forest, dead trees, rocks, and insects play a role. For example, the wax bees make provide various necessities that we use. I am part of this interrelationship, and so is my family. Family is at the center of the concept of permaculture and food production (Promoter A, interview, 2011).

In this way, the theoretical implications of permaculture that revolve around an understanding of humans as tied into a web of interrelations with all natural organisms, parallel Marti's nature discourse. Given Marti's iconic role in Cuban history, this parallel helps to legitimate the agroecological paradigm.

\subsection{Localism as Nature Discourse}

In addition to Revolutionary agrarian reforms, and Marti's influence, the impact of the Special Period on Cuban agriculture has functioned to frame a discourse of humans, and particularly farmers, in nature that revolves around the local; emphasis on the local is best contextualized in terms of the 1989 crisis, when self-sustenance became necessary in order to survive. In discussing the goals of ANAP's extension efforts, Castillo (Coordinator, Farmer-to-Farmer Movement, ANAP) explains the relation between the local and self-sustenance: to "achieve active participation of women and men; to involve their daughters, sons, and elders in the farming; this is the most important thing-- to arrive at a consciousness within the whole family to live in the farm according to the resources they have" (interview, 2011). Again, Castillo suggests

\footnotetext{
${ }^{52}$ Permaculture certainly falls within the parameters of ecological agriculture, but it is a distinct practice. Whitefield (2009: 64- 5) identifies two types of permaculture: early permaculture "focused on imitating natural ecosystems in a fairly direct way. Its key characteristics included...: a high level of plant and animal diversity, growing perennial food crops rather than annuals, and not disturbing the soil by digging or ploughing." The second type "is not dependent on direct imitations of nature; it depends on placing things in relation to each other so that beneficial relationships can be formed between them." Characteristics of each type of permaculture were readily apparent in the farm-spaces I observed.
} 
that certain communitarian ideals are realizable through agro-ecology; but she also discusses notions of livelihood and the use of local resources in essentially, the smallest-scale terms possible - of using only what is produced on the farm. Notably, these values that developed as a result of the Special Period are integral to agro-ecology. Palenzuela (President, ACTAF), for instance, not only stresses that self-sustainability is tied to using the resources available to a specific region, but she also indicates the importance of being responsive to the conditions of the local ecosystem. She maintains that "ACTAF promotes the use of waste products for planting, such as milk jugs, tires, and cookware. This can be done anywhere.... [We also] provide seedlings and plants depending on the types of soil and [terrain] elevation" of farms (conversation, 2011). Pérez (previous Director, CNSV) makes a similar point, but also speaks to the global tendency toward agro-ecology, and aligns localization with social and scientific change:

PÉREZ: Now the idea is to work for sustainable, subsistence, and low-input agriculture... using agronomical technology, and agricultural knowledge that is adapted to the local situation.

AYALA: Not to do technology of the Green Revolution ${ }^{53}$ that was the same for every place.

PÉREZ: This means that everyone, even professionals and older generations of professionals, are changing their approach, conceptions (interview, 2011).

Pérez goes onto comment:

In developed countries, there is much contamination. The residues of the industrial products of science mistreat nature-- this is not sustainable. It is necessary that people know better the laws that govern nature. It is important that not only the farmers but also the professionals know the local environment well; know the pests and the natural enemies that exist there -in order to understand what to do and why. Success depends upon adapting agriculture to the local environment-- farming should be [done] according to the possibilities of the place [agro-ecosystem] (interview, 2011).

\footnotetext{
${ }^{53}$ The Green Revolution refers to the industrial mechanization of agriculture, which is predicated upon monoculture ideology; monoculture ideology does not seek to adapt agricultural practice to local ecosystems, but applies the same technologies, seedlings, practices across ecosystems.
} 
Pérez points to a key principle of agro-ecology: that the practice of agriculture should be site and context-specific, and dependent upon the specific needs of individual agro-ecosystems.

Moreover, for Pérez, knowing the local environment is linked to understanding nature. This excerpt also expresses a parallel between the professional prioritization of the local and the importance attributed to agriculturalists (Chapter 5). In this way, the scientific knowledge of nature regarding localization, and the laws that govern nature, is intricately bound to farmers' knowledge of the local conditions of their farm.

\subsection{Nature Education}

In addition to Revolutionary and Special Period agrarian processes that are seen as necessitating a closer relation between Cubans and nature, preserving nature is bound to "the correct consciousness and well-being of humans" (Castillo, Coordinator, Farmer-to-Farmer movement, ANAP, interview, 2011). For agricultural professionals the notion of a correct consciousness is implicated in the advancement of agro-ecology. As such, one of the greatest perceived challenges to the continued expansion of ecological agriculture is the lack of education that teaches the importance of ecological consciousness. Gonzalez (Mentor/Professor, Marxism Department, UNISS) asserts, for instance:

It's a large challenge because it requires a change of mentality. The agro-ecological tendency exists because the state mechanisms, universities, and research centers promote this idea and they have had some effect, but it is not enough. We need strong projects regarding environmental education-- more stirring of people who promote these ideas in society. Cuba is in the vanguard in comparison to other Latin American countries but it does not mean that we have an ecological conscience. Ecology is not the dominant concept (interview, 2011)

Here Gonzalez speaks to state and professional-level motivations that shape and transcend the agro-ecological paradigm, but he also refers to local grassroots mobilization ("stirring of people"). Professionals from CNSV echo Gonzalez's call for education regarding the importance 
of nature:

PÉREZ (previous Director): The biggest challenge is in the capacity and education of society-- future society should respect nature more, and this should be taught in all levels of studies-- how to understand nature, and how to protect what is alive... to work for an environmental education of all the people (interview, 2011).

MONZÓN (retired Biocontrol Specialist): [A main challenge is] to continue working against the ignorance [lack of knowledge and understanding] of many people regarding the biological or agro-ecological alternative-- education and capacity-building of farmers and professionals. Because don't believe that the people who finish university are ready to do this [contribute to the agro-ecological movement], and some of them defend more [fervently] the use of chemicals (interview, 2011).

Monzón highlights the reality that within the Cuban professional community, adherence to an ecological imperative is not absolute.

Embedded within the concern for greater ecological education are "knowledges" of

nature. For example, Ayala (primary translator/Biocontrol Specialist, CNSV) contends:

The biggest challenge is to convince people that man is responsible for disturbing the environment and that man created the problem of the pest and the disease [within the soil and crops]. But if we have to feed ourself, we need to disturb the environment [through agriculture], and we need to learn that if we do this we have to repair the damage we did. And the main challenge is to show people that nature have potency enough to solve this problem and not to use artificial molecule [agro-chemical inputs] to do that.... I know that up to now we have not solved all the problems but I am absolutely sure that man will be able to do [this] because in nature are the solutions of all (interview, 2011).

Ayala, as I note in Chapter 4, subscribes to a reverence for the innate force nature; he expresses a dichotomy between the artificial and the natural, wherein what is natural carries a higher value.

Pérez (previous Director, CNSV) also conveys veneration for nature but does not subscribe to

the same strict dichotomy:

The biggest challenge is in the capacity and education of society-- future society should respect nature more, and this should be taught in all levels of studies-- how to understand nature, and how to protect what is alive... to work for an environmental education of all the people. This is not for the elimination of chemicals in agriculture-- I am not a purist [completely against the use of agro-chemical inputs]; modern agriculture cannot persist without the use of chemicals. But we need to use chemicals more rationally (interview, 2011). 
Pérez maintains that the chemical-dependency of modern agriculture is inevitable; he advocates, though, for the "rational use" of agro-chemicals. "Rational use" is certainly a discourse subscribed to by CNSV staff, and it implies a minimalist and situation-dependent use of agrochemicals. ${ }^{54}$ Ayala and Pérez represent two dominant perspectives in the professional community: one calls for the complete abandonment of agro-chemicals; the other necessitates a drastic reduction of the use of agro-chemicals, respectively. In this way, the abandonment or reduction of chemical inputs is enveloped within a larger discourse around the value of nature.

\subsection{Es Economía}

Despite state and institutional emphasis on a relation between the appreciation of nature and agro-ecological development, the majority ${ }^{55}$ of campesinos in my sample rarely expressed a sentiment of love for nature as tied to agricultural practice, nor did they articulate a "knowledge of nature" that accentuates ecological consciousness. For example, excerpts such as the following from an onion producer were rare:

Man and nature should be united, and man is working to protect nature. There is a political projection to protect nature, and the commandeering chief, Fidel, has talked a lot about preserving nature, and the importance it has. The farmers have a culture of nature and work to protect it, and there is much concern over this. We are learning (Producer 2. interview, 2011).

Although other producers made reference to Fidel Castro's position regarding nature, this producer was the only one to refer to a "culture of nature" among farmers. On the contrary, farmers highlighted material scarcity and resource limitation as predominantly dictating how they practice agriculture. It is certain that the experience of material austerity cuts across virtually all scales of Cuban society, and touches each household; although the discourse around

\footnotetext{
${ }^{54}$ Rational use of agro-chemicals ultimately revolves around Integrated Pest Management (IPM) (see Table 1.2: Common Agro-ecological Practices)
} 
such austerity is not exclusive to campesinos, they have had a unique experience of material restraint as it has massively transformed agricultural practice. Take for examples the following two quotes that express the campesino experience of the Special Period:

I have a bad back, and went to the doctor in Santa Clara, and the doctor told me, "You have to get used to that pain, to suffering that disease because it is yours and you have to live with it." I got used to living in the Special Period the same as I got used to this pain (Producer 10, interview, 2011).

JOHNSTON: How were the practices you use on the farm affected by the Special Period? PRODUCER 7: We had to use more animal traction; we had less fuel for irrigation. If you do not have fuel for irrigation, you cannot plant; productions decreased. The fuel administered to all CCSs and CPAs was reduced... to stop fuel in agriculture is like to stop breathing (interview, 2011).

Producer 10's observation of the Special Period could easily be that of any Cuban citizen; however, within the context of farming, the metaphor of back pain poignantly conjures the image of a hard working campesino forced to work under more harsh conditions. Furthermore, as Producer 7 conveys, lacking mechanical inputs and fuel resources are tantamount to their experience of the transition to ecological agriculture.

As Table 6.1 below shows, among the many practices that producers attributed to lacking agricultural resources and money are: the rational use of chemical inputs due to economic limits rather than ecological concern; fruit tree plantations as a means to creating farm biodiversity, but also because once such plantations are established, they require little input; dependency on rain rather than irrigation; the use of a biodigester to properly treat pig wastes due to an increase in pig production with the intent of gaining more profit; use of organic composts because the cycle of input and output is completely restricted to farm resources, and thus highly economical; and, finally, the production of hortalizas (vegetables) because you can save the seeds, which, again, is economically efficient. 
Table 6.1: Economic Restraint that Dictates Campesino Use of Agro-ecological Practices

\begin{tabular}{|c|c|c|}
\hline Producer & Quote & Implications \\
\hline Producer 5 & $\begin{array}{l}\text { I do not prepare the same chemical and } \\
\text { dose for all the crops. I use according to the } \\
\text { need and stage of the plant.... The main use } \\
\text { of pesticide will be in onion, normally } \\
\text { banana does not need too much pesticide } \\
\text { [AYALA: so you can affect one part of the } \\
\text { ecosystem but not all the ecosystem]. The } \\
\text { treatment is not generalized for the whole } \\
\text { farm. }\end{array}$ & $\begin{array}{l}\text { Not generalizing } \\
\text { chemical treatment to } \\
\text { whole farm points to } \\
\text { a "rational" use of } \\
\text { chemical inputs, and } \\
\text { to Integrated Pest } \\
\text { Management (IPM). } \\
\text { - Expresses ecological } \\
\text { but also economical } \\
\text { rationality due to } \\
\text { material limits. }\end{array}$ \\
\hline $\begin{array}{l}\text { Ayala (primary } \\
\text { translator/Biocontrol } \\
\text { Specialist, CNSV) } \\
\text { speaking in reference to } \\
\text { Producer } 5\end{array}$ & $\begin{array}{l}\text { It is important to understand that, for } \\
\text { example, mangoes- after the initial } \\
\text { investment to buy the plant and the first few } \\
\text { years [of production that require more care } \\
\text { and inputs], after that, they produce without } \\
\text { any work and you don't have to apply } \\
\text { nothing. The plantation of guava, which is } \\
10 \text { years old has paid back the money he } \\
\text { [Producer 5] invested... it continues to } \\
\text { produce but it requires little labour and } \\
\text { investment. Onion needs more labour and } \\
\text { more money to produce; but, at the same } \\
\text { time, in a short period of time it yields } \\
\text { much profit. The equilibrium between a } \\
\text { short crop [one harvest] like onion and long } \\
\text { crop [continues to produce over several } \\
\text { harvests] like fruit is good from an } \\
\text { economical standpoint. }\end{array}$ & $\begin{array}{l}\text { Crop diversity is both } \\
\text { ecologically and } \\
\text { economically } \\
\text { sustainable. }\end{array}$ \\
\hline Producer 3 & $\begin{array}{l}\text { If you don't have enough diesel [usually } \\
\text { used to run a turbine], it is difficult to } \\
\text { irrigate. [After the Special Period] we } \\
\text { learned to depend more on the weather and } \\
\text { nature. We had to pray to God for rain, and } \\
\text { to depend on him for this. }\end{array}$ & $\begin{array}{l}\text { The dependency on } \\
\text { nature, here, is not } \\
\text { aligned to an } \\
\text { ecological } \\
\text { consciousness, but to } \\
\text { a concern for } \\
\text { productivity. If } \\
\text { productivity fails, } \\
\text { there is no profit. }\end{array}$ \\
\hline
\end{tabular}




\begin{tabular}{|c|c|c|}
\hline Producer 7 & $\begin{array}{l}\text { I have always produced pigs for } \\
\text { consumption, but I also wanted to sell pigs } \\
\text { to the state. I started with a small area, and } \\
\text { saw that it was profitable so decided to } \\
\text { increase the production. I had an agreement } \\
\text { with the state to have less than } 50 \text { pigs but I } \\
\text { wanted to have more. This meant that I had } \\
\text { to make a residual dam to properly deal } \\
\text { with the pig wastes. Over } 50 \text { pigs is a large } \\
\text { enough production that the wastes could } \\
\text { contaminate the water... but the residual } \\
\text { dam would have taken up too much crop } \\
\text { space. So I decided to have the biodigester } \\
\text { installed to fulfill } 3 \text { objectives: to raise pigs } \\
\text { according to the restrictions of the state; to } \\
\text { take advantage of the biogas for cooking; to } \\
\text { use the residuals [liquid and solid] as } \\
\text { fertilizer. }\end{array}$ & $\begin{array}{l}\text { Refers to use of } \\
\text { biodigester for } \\
\text { ecological reasons: } \\
\text { prevent from water } \\
\text { contamination; biogas } \\
\text { is energy efficient; } \\
\text { organic fertilizer with } \\
\text { waster residuals. } \\
\text { Impetus to increase } \\
\text { pig production, } \\
\text { though, is } \\
\text { economical. }\end{array}$ \\
\hline \multirow[t]{2}{*}{ Producer 12} & $\begin{array}{l}\text { I make and use worm humus. This practice } \\
\text { is completely economical because it does } \\
\text { not cost anything-- all inputs are from the } \\
\text { farm and all outputs go directly back into } \\
\text { farm. It is wonderful for all crops. }\end{array}$ & $\begin{array}{l}\text { Production of worm } \\
\text { humus, and other } \\
\text { organic composts, is } \\
\text { both economically } \\
\text { and ecologically } \\
\text { sustainable. }\end{array}$ \\
\hline & $\begin{array}{l}\text { The production of hortalizas [vegetables] is } \\
\text { economical because everything is produced } \\
\text { in the farm. You can save the seeds, and } \\
\text { there is no need to buy inputs. }\end{array}$ & $\begin{array}{l}\text { Producing vegetables } \\
\text { is both ecologically } \\
\text { and economically } \\
\text { sustainable, but this } \\
\text { farmer emphasizes } \\
\text { the economic. }\end{array}$ \\
\hline
\end{tabular}

It is important to mention that despite campesino expressions of hardship resulting from the Special Period, many also considered that the material scarcity, which forced the nation to innovate and adopt alternatives, is a positive outcome. However, I seek to demonstrate that the state-supported discourses that come to be attached to political processes do not immediately reinforce an ecologically conscious "knowledge of nature" among campesinos. Rather, ecological sustainability cannot be separated from economic sustainability, and it is economy that highly motivates which practices producers adopt. Producer 7 astutely conveys this reality: 
"To care for nature, you have to use ecological practices, but the livelihoods of all farmers are based on their production, so they have to produce quickly and obtain money" (interview, 2011).

\subsection{Conclusion: Eclipsing Discourse}

The interplay between ecological and economic sustainability exemplifies the on-the-ground complexity of agrarian transformation. This interplay, in my opinion, is often overshadowed by state and global processes that give predominance to discourses that center on nature, and ecological consciousness. Moreover, the contested terrain of this interplay is epitomized by a contradiction I observed that revolves around economic development. On one hand, some authors highlight the concern that Cuban economic growth will not only provide greater access to agricultural resources, including chemical inputs, but will also subvert the agro-ecological paradigm; these authors have found a correlation between economic recovery and return to industrial agricultural practices (Couret 2001: 15; Cruz and Medina 2003: Premat 2005: 155). Underlying the threat of economic recovery, of course, is campesino resistance to state-wide control of chemical inputs. As my mentor explained, Revolutionary agrarian reforms sought to improve the work conditions of local farmers. In this way, farmers became "beneficiaries" of the state, whereby they received ample resources, such as gasoline, chemical fertilizers and pesticides, seeds, and machinery. After the 1989 crisis, though, state limits on the resources that campesinos consider as necessities fostered resentment and resistance (Gonzalez, Mentor/Professor, Marxism Department, UNISS, conversation, 2011). Interestingly, despite this resistance, and observations that economic growth, in some cases, has fostered a return to industrial practices, most professionals and campesinos in my sample were of the opinion that economic recovery would have little to no impact on the continued expansion of agro-ecology. On the other hand, and herein lies the contradiction, both professionals and producers alike 
expressed the sentiment that "Cuba is an agriculture of opportunity" (CNSV employee,

conversation, 2011) ${ }^{56}$ In one sense of the term, Cubans have taken the Special Period as an

opportunity to develop alternative agriculture. In another sense, opportunity conveys a scenario wherein farmers will make use of all available resources; if chemical inputs are available, they will use them.

${ }^{56}$ This comment was apparently made by Alfredo Jordán Morales, who held the position of Cuba's Minister of Agriculture at the height of the Special Period crisis. 


\section{Chapter 7: Conclusion}

\subsection{Introduction}

In conclusion, this thesis has attempted to achieve a nuanced account of the local farmer experience and interpretation of the agro-ecological movement. Indeed, as Section 7.2 delineates, exploring the dynamic interplay between state and local forces and actors has been integral to understanding and illuminating these nuances. Within this interplay, there are certain discrepancies between not only the discourses, but also the motivations of state and agricultural professionals, and farmers. One of these discrepancies, which both Chapters 4 and 6 extrapolate upon, centers on ecological versus economical security and sustainability; Section 7.3 explores this discrepancy in order to provide a more thorough contextualization of the perceived fragility of the agro-ecological paradigm. Finally, Sections 7.4 and 7.5 outline the limitations to this study, and potential future lines of inquiry.

\subsection{State and Local Dynamics}

JOHNSTON: Who paints those images? [Pointing to a billboard that features the black silhouette of a farmer wearing a cowboy hat, and reads, Campesino, siempre un paso mas (Farmers, always one step ahead.)] CNSV EMPLOYEE: What do you mean? JOHNSTON: Who is responsible for creating that propaganda? CNSV EMPLOYEE: The [Communist] Party or other organizations. JOHNSTON: Like Committees for the Defense of the Revolution, ${ }^{57}$ ANAP, CNSV... CNSV EMPLOYEE: Yes.

JOHNSTON: But it must be in support of the state? CNSV EMPLOYEE: Yes (conversation, 2011).

Fundamental to the theoretical import of this research is the interrelationship between state and local forces and actors; the conversation above serves to foreground the complex and shifting nature of this relationship. For instance, I noted in the introduction to this thesis that Campesino,

\footnotetext{
${ }^{57}$ Committees for the Defense of the Revolution (CDR) are essentially "neighbourhood watch" groups that support social welfare and report on counter-Revolutionary activity. It should be noted, however, that Cubans can and do speak out against the Revolution, and the current state of their economy and living conditions. It is only direct action against the State that is penalized (CNSV employee, conversation, 2011).
} 
siempre un paso mas (Farmers, always one step ahead) is a slogan that attests to the important function of farmers as local actors in agrarian reform. Certainly campesinos willingly contribute to the transition to agro-ecology, and this is an important point. Recall the ANAP promoters discussed in Chapter 5 that provide training, and guidance for other campesinos to follow. Also, in her discussion of the education of regular citizens into "model" urban gardeners, Premat (2009: 49) contends that in this process of endorsing agro-ecology, some producers have "left an imprint on official [state] formulations, as attested to by the way the experiences and 'innovations' of model producers... have been integrated into official representations of ideal sustainability." Significantly this integration points to the fact that the agro-ecological paradigm, to some extent, relies on the traditions, empirical observations and innovations of local producers.

However, while highlighting the agency of local actors, Premat also maintains that "model" producers signify the success of the Cuban state and agricultural institutions, ... in bringing producers in line with official goals and programs, [which] further underscores not just the continuing power of the Cuban state to insinuate its will into the most quotidian of activities, but its ability - despite its lack of material resources-to enlist even those apparently most marginalized sectors of the population in a project [the agro-ecological movement] that ultimately is being represented as one of the latest achievements of Cuban socialism (Ibid.).

In this sense, the state level mechanisms discussed in this thesis, such as the agrarian policies to increase food security and reduce imports, the promotion of innovative forms of low-input, ecological agriculture, and rational use of chemicals, and emphasis on both ecological and economic sustainability, while simultaneously articulating the importance of nature and ecological consciousness, are means through which the state "insinuate[s] its will" (Ibid.). Again, I must refer back to the conversation at the start of this section that solidifies the reality that local participation is instrumental and encouraged, but must also exist within strict ideals set out by the 
state: propaganda must be state-sanctioned. However, I have also sought to convey that although the state and agricultural professionals certainly shape agricultural practice, local agency exists both discursively and materially, and at times, through resistance.

Chapter 4 demonstrates what might be referred to as a rift between state and professional understandings of food security, versus that of local producers. State initiatives aimed at increasing food security are discursively framed within a scientific "knowledge of nature" that revolves around farm biodiversity. Moreover, the act of conserving biological diversity is discursively tied to national security, which adds greater legitimization to the transition to lowinput, ecological agriculture. Yet, campesinos tend to internalize food security as linked to their performance (ability to produce and economically sustain their families) as producers.

Ultimately, in the processes of internalization and identity construction, the weight of responsibility to produce contributes to a level of chemical-dependency that, in some instances, is more extensive than the rational use that the state endorses.

Chapter 5 follows the trajectory of Gropas' (2006: 1) assertion that "political changes in Cuba are made manifest in... rural landscape[s]." In this way, the agro-ecological movement has engendered discourses of ideal producers (such as promoters and agriculturalists) and practices (agro-ecological versus agro-chemical) that are materially evident in farm-spaces. In Lefebvre's terms, the lived dimensions of farm-spaces are also the site at which resistance to state ideals are evident. Akin to the way in which professional and producer discourses are both overlapping and distinct, farm-spaces are repositories of contestation. Farm-spaces, then, demonstrate how the state encourages traditional and local knowledge, but the point at which such knowledge runs counter to the agro-ecological paradigm, it is perceived as resistance.

Finally, Chapter 6 examines to what extent state-supported discourses of nature and 
ecological consciousness are driving forces behind agro-ecology. Although the Cuban state does endorse economically sustainable practices, there is an underlying motivation and presumption that further education and insinuation of ecological values will ensure the continued expansion of agro-ecology. In some sense, though, prioritizing such values as the way forward serves to eclipse how concerns over livelihood, economic gain and material frustrations serve to delimit the practices and discourses of rural campesinos. Fundamentally, by exploring the discrepancies between how agricultural professionals and producers talk about and experience the agroecological agenda, this thesis demonstrates that agro-ecology is a contested terrain fraught with subtle subversions and contradictions that revolve around chemical dependency, agricultural practices that are not perceived as ideal, and profit-motivation among rural campesinos. In this way, the reductionist nature of discourse is laid bare.

\subsection{Incomplete Transition}

Furthermore, agro-ecology as a contested terrain is epitomized in the transitional nature of farmspaces, described in Chapter 5; these spaces illustrate the "incompleteness" of the transition to ecological agriculture. Moreover, this "incomplete" picture gives rise to tacit social anxieties, as well as to certain discursive formulations. To repeat an important point made in Chapter 2, what is useful about Foucault's concept of discourse is that it "enables us to understand how what is said fits into a network that has its own history and conditions of existence" (Barrett 1991: 126). Barrett goes on: "The description of the events of discourse poses a quite different question: how is it that one particular statement appeared rather than the other? (Ibid.) Significantly, though, hegemonic discourses do not necessarily quash counter-discourses, they simply frame them as resistance. Thus, within this transitional context of Cuban agriculture, the "ecological" is pitted against the "chemical," and perhaps even more importantly, the "agriculturalist" is pitted against 
the "businessman." I explain in Chapter 5 that the agriculturalist discourse is tied to generational producers who retain some traditional agricultural knowledge and culture, but also to a broader discourse around innovation within the context of Special Period material limitation. During field visits, the agriculturalist discourse was often framed in contrast to campesinos that were predominantly economically motivated; these farmers were referred to as "businessmen" and were perceived to retain a greater dependency on chemical inputs for it is such inputs that ensure successful and bountiful harvests. For CCS farmers, a high yield guarantees not only that they will meet the conditions of state contracts, but also that they may supplement their income with any remaining produce that can be sold according to supply and demand. The businessmanfarmer is an apt metaphor that embodies professional concerns that agro-ecology is a provisional model that will give way with continued economic development; however, the metaphor also symbolizes professional anxieties around agrarian reforms that are tied to increasing food security. As I mention in Chapter 4, the Cuban state has been distributing lands to ordinary citizens, or farmers, who will use the land to produce food since 2008. It is these new farmers that agricultural professionals perceive as vulnerable to becoming "businessmen," and as such, threaten the agro-ecological paradigm.

Notably, constructs like the agriculturalist versus the "businessman," also point to the relationship between discourse and identity. The agro-ecological paradigm, then, has functioned to construct various farmer identities according to the extent to which they reproduce and enact ideals of ecological agriculture. In this way, agricultural practices that are construed as either ecological or chemical-based become emblems of identity; for example, the promoter identity hinges on the extensive use and adoption of agro-ecological practices, as well as the willingness to spread agro-ecological knowledge. Additionally, the agriculturalist and "businessman" 
identities serve to epitomize what might be construed as "performances" of authentic and inauthentic farmer-hood. What complicates this authenticity, moreover, is the fact that for many farmers in my sample, state restrictions on chemical inputs hinders what they consider to be the mark of true farmer-hood: the capacity to produce high yields. Ultimately, the diverse ways in which identity is constructed reflects not only state, and professional-level concerns, but also the personal concerns of farmers regarding the advancement of ecological agriculture.

What is more, debate that centers on the origin of Cuba's agro-ecological movement, which I briefly alluded to in Chapters 1 and 2, contextualizes perceived threats to the agroecological model. For example, Levins and Stricker (2007: 118) argue that Cuban socialism has promoted an ecological consciousness of cooperation among humans, but also with nature. Basically, Stricker asserts that socialism fosters an understanding of humans as existing within the limits of nature; such understanding creates a sensibility that revolves around ecological sustainability (Ibid.). In many ways, Stricker's opinion is valid in that both agricultural professionals and producers express sentiments of reverence for nature and an ecological consciousness as taught by icons like Martí, and as facilitated by Revolutionary processes of land re-structuring. However, the fact that agro-ecology has become more systematically integrated as a result of the Special Period, points to two possibilities: first, that agro-ecology is, in some way, a temporary model that is dependent on economic and material restraint; and second, that Cuban socialism does not necessarily necessitate ecological consciousness. Indeed, within the context of Special Period hardship, as Chapter 6 demonstrates the ecological and the economical must be taken together.

As such, and in order to subvert the link between economic prosperity and continued chemical use in rural farming, professionals and producers alike have suggested a system of 
certification for ecologically produced foods. Similar to Canada and the United States, these participants argue that foods that have been ecologically produced, and certified, should be valued at a higher cost in agricultural markets. When asked, for example, if he considers himself $100 \%$ agro-ecological, Producer 4 responded: "Not $100 \%$. If the state supported me by certifying ecological products, I would become a completely ecological producer. But otherwise, I will continue to use chemicals" (interview, 2011). In this way, profit incentives would promote the continued expansion of agro-ecology, rather than chemical-dependency.

\subsection{Study Limitations}

In general, the limits of this research project revolve around translation; gate-keeping; and the sample of study participants. As discussed in the introduction to this thesis, translation necessitates a power dynamics and co-construction of knowledge; as a result, the data collected for this research project has been doubly mediated: through the translators and through the process of transcription. Moreover, the process of transcribing was also mediated by my limited fluency in Spanish, whereby certain nuances in the interviews may have been missed. Data collection has also been influenced by the presence of CNSV extension workers, and faculty of the University of Sancti Spiritus; in this way, the observations put forth in this thesis are colored by their ideological stances. Although these stances are varied, each of them advocate for the reduction or complete abandonment of chemical use, a position that is pitted against the entrenched tradition of chemical dependency among some rural campesinos. In terms of gatekeeping, it is also important to recognize that the conclusions drawn in this thesis are substantiated by the knowledge that campesinos buy chemicals on the black market. Although many farmers acknowledged their participation in the black market, I did not observe any dealings of this sort. Furthermore, I was never privy to the type or quantity of chemical inputs 
that the state distributes to farmers. These considerations have certainly inhibited my ability to provide a well-rounded account of campesino dependence on chemicals, and the incumbent resistance to state control of agricultural inputs.

Additionally, the sample of producer-participants was limited by size and region. Given that there are 36,000 campesinos in Sancti Spiritus, it is difficult to draw substantial conclusions from a sample of 12 . The sample, moreover, was principally taken from two regions, Banao and Cabaiguán, where producers traditionally grow onion and tobacco, respectively. Onion is a cultivo potenciado (enhanced crop), and tobacco is integral to the Cuban economy; as such, the production of these crops is supported by the state, part of which means that producers receive the agricultural inputs, including chemical pesticides and fertilizers, that will ensure a successful harvest. Hence, it follows that onion and tobacco producers would express a certain level of chemical-dependency, as opposed to those who produce crops that are not state-supported. In the end, this project merely scratches the surface of Cuba's complex agricultural transition. Nonetheless, the insights represented here are an important window onto the rural campesino experience of the agro-ecological paradigm, and I intend to use them as a starting point for future work with rural Cuban campesinos.

\subsection{Potential Next Steps}

Given the context of post-Soviet agricultural transformation, and increasing global concern over issues of ecological sustainability and food security, the subject of Cuban agriculture has been extensively studied from scientific and socio-cultural perspectives. However, Medina and Cruz (2003: 10) contend that much research of Cuban agriculture presents "the technical and productive aspects" of ecological agriculture, over socio-cultural impact. Notably, my mentor at the University of Sancti Spiritus, Gonzalez, in addition to other faculty members, also expressed 
the opinion that farmer perspectives were under-represented in scholarly accounts in Cuba. Perhaps a contributing factor to such under-representation is the fact that traditional agricultural knowledge is not always valued, and at times seen as inhibiting agro-ecological development. Contrarily, though, some agricultural extension workers and farmers assert that the return to traditional practices since the 1990s has functioned to not only revive Cuban culture, but also to necessitate a more central role for women in farming communities. In terms of cultural revivals, Rosenblatt (2011: 412) states that they "not only respond to their contexts but they also become contexts themselves... As a consequence, such revivals become part of how people live in the world, influence how they interpret the world, and thus end up influencing the ways people are shaped by the world." Thus, understanding the role of traditional knowledge and culture in the agro-ecological movement is one means to fostering more sustainable frameworks of knowledge exchange between agricultural extension services, such as ANAP and CNSV, and producers.

Moreover, the data collected for this thesis will contribute to my doctoral research, which will potentially entail conducting a one-year project evaluation at Cuba Nueva, a farm cooperative in Sancti Spiritus, Cuba. Cuba Nueva is presently undergoing a conversion from chemical-dependent practices to ecological agriculture. The conversion, which began in October 2009 , involves negotiating the different knowledge bases that extension workers and farmers work from; that is, scientific versus traditional agricultural and local farmer knowledge, respectively. This project could continue to grapple with how local farmers perceive the shift from chemical to ecological practices, but it would also identify socio-cultural indicators to assess the impact and sustainability of the farm conversion within the local community. Interestingly, Cuba Nueva is intended to function as a model for nearby farmers to visit, and observe that ecological agriculture is not only sustainable, but also profitable. As such, one of the 
more practical outputs of conducting a project evaluation of this sort would be the design of a framework from which to base future farm conversions on.

A tertiary avenue for future research extrapolates upon the link between economic profit and continued chemical use among producers by comparing the "businessman" discourse to the discourse that casts ANAP promoters as embodying a sustainable and ecologically conscious lifestyle (recall that only 1000 producers in Sancti Spiritus are perceived as fully committed to agro-ecology). Take, for example, the following comments from Promoter A:

The food we are producing here has great alimentary, emotional, and sustainable value. What is very difficult is that I don't know if the people will understand. To produce and sell wine, for example, is very expensive according to its real productive value. All food we eat contains a "real" value. If you have a pair of shoes that you obtain raising an animal with the same color of fur as those shoes, and you have participated in the whole process of production and manufacture up until the final product, you would feel different about those shoes. They have their own history (interview, 2011).

This testimony confirms Appadurai's (1986) contention that things, commodities or otherwise, have "social lives." Undoubtedly, though, this producer is also espousing Marx, and advocates for a sustainable lifestyle that is not predicated on economic gain or the capitalist system that alienates the worker, and fetishizes the commodity. Indeed, this Promoter also asserts: "If Communism is real, then it can be realized through these principles of sustainable living" (interview, 2011). Against the backdrop of what Gropas (2006: 270) refers to as "an incipient process of capitalist restoration, albeit within the confines of la revolucion," this idea of bridging the gap between production and consumption raises an interesting question: To what extent can the agro-ecological paradigm function as a revival of socialist ideals? 


\section{Bibliography}

Agriculture and Agri-Food Canada.

2009 Agri-Food Past, Present and Future Report: Cuba. November 12, 2011.

$<$ http://www.ats.agr.gc.ca $>$

Alexander, Richard J.

2009 Framing Discourse on the Environment: A Critical Discourse Approach. New York: Routledge.

Appadurai, Arjun

1986 "Introduction: Commodities and the Politics of Value." Pp. 3- 63 in Arjun Appadurai (ed.), The Social Life of Things: Commodities in Cultural Perspective. Cambridge: Cambridge University Press.

Association of Small Private Farmers.

2003 "Metodología para la promoción de la agricultura ecológica: actividades y herramientas." Movimiento Agroecológica de campesino a campesino. Havana, Cuba: ANAP.

Ballamingie, Patricia and Sherrill Johnson.

2011 "The Vulnerable Researcher: Some Unanticipated Challenges of Doctoral Fieldwork." The Qualitative Report. 16 (3): 711- 29.

Barrett, Michele.

1991 "History, Discourse, 'Truth' and Power: Foucault's Critique of Ideology." Pp. 123- 56. The Politics of Truth: From Marx to Foucault. Stanford: Stanford UP.

Berg, Bruce L.

2001 Qualitative Research Methods for the Social Sciences. $4^{\text {th }}$ Ed. Boston: Allyn and Bacon.

2009 Qualitative Research Methods for the Social Sciences. $7^{\text {th }}$ Ed. Boston: Allyn and Bacon.

Bowen, Sarah and Patricia Martens.

2005 "Demystifying Knowledge Translation: Learning from the Community." Journal of Health Services and Research Policy. 10 (4): 203- 11.

Buchmann, Christine.

2009 "Cuban Home Gardens and Their Role in Social-Ecological Resilience." Human Ecology. 37: 705- 721.

Burley, R.

2006 Cuba, The Accidental Revolution, Parts 1 and 2- The Nature of Things. Dir. R. Burley. Toronto: Canadian Broadcasting Corporation.

Castree, Noel. 
2001 "Socializing Nature: Theory, Practice, and Politics." Pp. 1- 21. Social Nature: Theory, Practice and Politics. Eds. Noel Castree and Bruce Braun. Massachusetts: Blackwell Publishing.

2005. Nature. London: Routledge.

Communist Party of Cuba.

2011 Lineamentos de la política, económica, y social del partido y la revolución. VI Congreso del partido comunista de Cuba.

Couret, Dania Gonzalez

2001 "Ecological Design in Cuba- Theory and Practice." Global Built Environment Review. 1.(1): 11-16.

Cruz, M. C. and R.S. Medina.

2003 Agriculture in the City: A Key to Sustainability in Havana, Cuba. Ottawa: International Development Research Council.

Cuba's Socialist Renewal

2011 Translation: Guidelines debate 18, Agriculture. October 23, 2011. $<$ http://cubasocialistrenewal.blogspot.com/search?q=part+18>

Darier, Eric.

1991 "Foucault and the Environment: An Introduction." Pp. 1- 33. Discourses of the Environment. Malden, Massachusetts: Blackwell.

Demeritt, David.

2001 "Being Constructive about Nature." Pp. 22- 40 in Noel Castree and Bruce Braun (eds.), Social Nature: Theory, Practice, and Politics. Massachusetts: Blackwell Publishing.

Dove, Michael R.

2005 "Shade: Throwing Light on Politics and Ecology in Contemporary Pakistan." Pp. 217- 38 in Susan Paulson and Lisa L. Gezon (eds.), Political Ecology Across Spaces, Scales and Social Groups. New Brunswick: Rutgers UP.

Escobar, Arturo.

1998 "Whose Knowledge, Whose Nature? Biodiversity, Conservation, and the Political Ecology of Social Movements." Journal of Political Ecology. 5 (1): 53 82.

Food and Agriculture Organization.

2001 The State of Food Insecurity in the World 2001. Rome.

Foucault, Michel.

1980 "Power and Strategies." Pp. 134- 45 in Colin Gordon (ed.), Power/Knowledge: Selected Interviews and Other Writings 1972-1977. New York: Harvester Wheatsheaf. 
1984 "Space, Knowledge and Power." Pp. 239- 56 in Paul Rabinow (ed.), The Foucault Reader. New York: Vintage Books.

Funes, Fernando. Luis Garcia, Martin Bourque, Nilda Perez, and Peter Rosset.

2002 Sustainable Agriculture and Resistance: Transforming Food Production in Cuba. Oakland: Food First Books.

Gezon, Lisa L. and Susan Paulson.

2005a "Place, Power, Difference: Multiscale Research at the Dawn of the Twenty-First Century." Pp. 1- 15 in Susan Paulson and Lisa L. Gezon (eds.), Political Ecology Across Spaces, Scales and Social Groups. New Brunswick: Rutgers UP.

2005b "Politics, Ecologies, Genealogies." Pp. 17- 37 in Susan Paulson and Lisa L. Gezon (eds.), Political Ecology Across Spaces, Scales and Social Groups. New Brunswick: Rutgers UP.

Gropas, Maria.

2006 "Landscape, Revolution and Property Regimes in rural Havana." Journal of Peasant Studies. 33 (2): 248- 77.

Grupo Especializado en Sistemas Integrados de Manejo de Plagas (GESIMAP).

1999a Anexo: Programa de Manejo Agroecologico de Plagas de la Cebolla. Sancti Spiritus, Cuba: Impreso por Publicigraf.

1999b Boletin Especial: Las Principales Plagas de la Cebolla: Elaborado para el contrato de asistencia tecnica a los productores de cebolla en Banao, Sancti Spiritus. Sancti Spiritus, Cuba: Impreso por Publicigraf.

Kapcia, Antoni.

2008 "Rescuing the Revolution in the 1990s: Crisis, Adaptation and the Return to Basics.” Pp. 157- 78. Cuba in Revolution: A History since the Fifties. London: Reaktion Books.

Lefebvre, Henri.

1991 The Production of Space. Oxford: Blackwell.

Levins, Richard.

1990 "The Struggle for Ecological Agriculture in Cuba." Capitalism, Nature, Socialism. 1. (5): $121-41$.

2005 "How Cuba is Going Ecological." Capitalism, Nature, Socialism. 16. (3): 7-25.

Morgan, Faith, Pat Murphy and Megan Quinn Bachman.

2006 The Power of Community: How Cuba Survived Peak Oil. Dir. Faith Morgan. Ohio: The Community Solution.

Nassif, Ricardo. 
1994 “Jose Marti (1853-95)." Prospects: the Quarterly Review of Comparative Education. 24 (1/2): 107- 19.

Oxfam.

2010 Oxfam in Cuba. August 21, 2010. <http://www.oxfam.ca/what-we-do/where-wework/americas/cuba>

Pain, Rachel, Sara Kindon and Mike Kesby.

2007 "Participatory Action Research: making a difference to theory, practice and action." Pp. 26- 32 in Sara Kindon, Rachel Pain and Mike Kesby (eds.), Participatory Action Research Approaches and Methods: Connection people, participation and place. London: Routledge.

Palmié, Stephan.

2002 Wizards and Scientists: Explorations in Afro-Cuban Modernity and Tradition. Durham: Duke University Press.

Paulson, Susan, Lisa Gezon and Michael Watts.

2003 "Locating the Political in Political Ecology: an Introduction." Human Organization. 62 (3): 205- 17.

Perfecto, I. "The Transformation of Cuban Agriculture after the Cold War." American Journal of Alternative Agriculture. 9.3 (1994): 98-107.

Phinney, Richard.

2003 Seeds in the City: the Greening of Havana. Dir. Richard Phinney. Ottawa: Knowledge in Action.

Premat, Adriana.

2005 "Moving Between the Plan and the Ground: Shifting Perspectives on Urban Agriculture in Havana, Cuba." Pp. 153- 85. Agropolis: The Social, Political and Environmental Dimensions of Urban Agriculture. Ottawa: International Development Research Centre.

2009 "State Power, Private Plots and the Greening of Havana's Urban Agriculture Movement." City and Society. 21 (1): 28- 57.

Rabinow, Paul and Nikolas Rose.

1994 The Essential Foucault: Selections from the Essential Works of Foucault 1954-1984. New York: The New P.

Rosenblatt, Daniel.

2011 "Indigenizing the City and the Future of Maori Culture: The Construction of Community in Auckland as Representation, Experience, and Self-Making." American Ethnologist. 38 (3): 411- 29. 
Rosset, Peter and Medea Benjamin.

1994 The Greening of the Revolution: Cuba's Experiment with Organic Agriculture. Melbourne, Australia: Ocean P.

Rosset, Peter. M.

1998 "Alternative Agriculture Works: the Case of Cuba." Monthly Review: An Independent Socialist Magazine. 50 (3): 137- 46.

Stevens, Charles J.

2005 "Symbolic Action and Soil Fertility: Political Ecology and the Transformation of Space and Place in Tonga." Pp. 154- 73 in Susan Paulson and Lisa L. Gezon (eds.), Political Ecology Across Spaces, Scales and Social Groups. New Brunswick: Rutgers UP.

Stricker, Pamela.

2007 "People, Nature and Development from the Cuban Point of View." Pp. 105- 19. Toward a Culture of Nature: Environmental Policy and Sustainable Development in Cuba. Toronto: Lexington Books.

Temple, Bogusia and Alys Young.

2004 "Qualitative Research and Translation Dilemmas." Qualitative Research. 4 (2): 161 - 78.

Waitt, Gordon.

2005 "Doing Discourse Analysis." Pp. 163- 91 in Iain Hay (ed.), Qualitative Research Methods in Geography. Melbourne: Oxford UP.

Weinreb, Amelia Rosenberg.

2009 Cuba in the Shadow of Change: Daily Life in the Twilight of the Revolution. Gainsville: UP of Florida.

Whitefield, Patrick.

2009 "Permaculture Design: Designing Our Lives with Nature." Pp. 64- 9 in Arran Stibbe (ed.), The Handbook of Sustainability Literacy: Skills for a Changing World. Ed. Arran Stibbe. Foxhole, UK: Green Books.

Wolcott, Harry F.

2005 The Art of Fieldwork. Walnut Creek, CA: AltaMira Press.

Wong, Josephine Pui-Hing and Maurice Kwong-Lai Poon.

2010 "Bringing Translation Out of the Shadows: Translation as an Issue of Methodological Significance in Cross-Cultural Qualitative Research." Journal of Transcultural Nursing. 21 (2): 151- 58.

Zerner, Charles.

1996 "Telling Stories About Biological Diversity." Pp. 69- 101 in S. Brush and D. Stabinksy (eds.), Valuing Local Knowledge: Indigenous People and Intellectual Property Rights. Washington, D.C.: Island P. 
Appendix A: List of Participants

\begin{tabular}{|l|l|l|l|}
\hline \multicolumn{5}{|c|}{ Producer Participants } \\
\hline \multicolumn{5}{|c|}{ Region } & Identified As & Preferred Practice & $\begin{array}{c}\text { Generational/Non- } \\
\text { generational }\end{array}$ \\
\hline Banao & Producer 1 & Agro-ecological & Generational \\
\hline Banao & Producer 2 & Agro-ecological & Generational \\
\hline Banao & Producer 3 & Agro-ecological & Non-generational \\
\hline Banao & Producer 4 & Agro-chemical & Generational \\
\hline Banao & Producer 5 & Agro-chemical & Non-generational \\
\hline Cabaiguán & Producer 6 & Agro-ecological & Non-generational \\
\hline Cabaiguán & Producer 7 & Agro-ecological & Generational \\
\hline Cabaiguán & Producer 8 & Agro-chemical & Generational \\
\hline Cabaiguán & Producer 9 & Agro-chemical & Generational \\
\hline Cabaiguán & Producer 10 & Agro-chemical & Generational \\
\hline Taguasco & Promoter A & Agro-ecological & Non-generational \\
\hline Sancti Spiritus & Promoter B & Agro-ecological & Generational \\
& & & \\
\hline
\end{tabular}

\section{Distribution of Producer Participants}

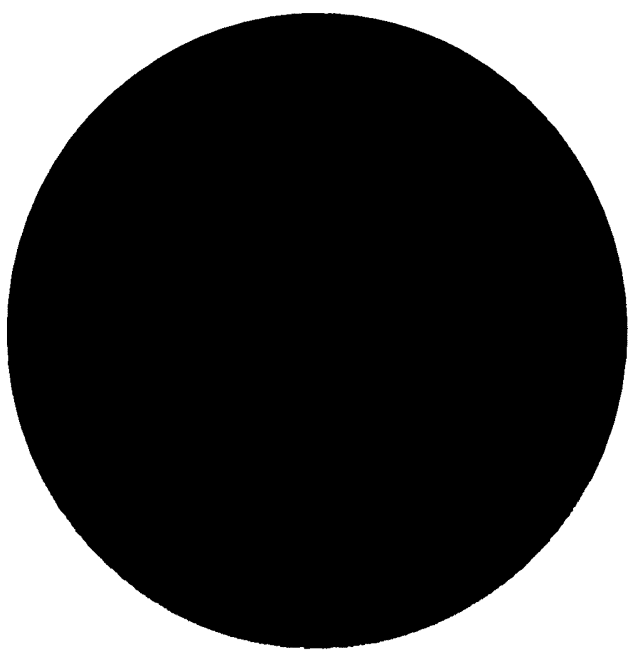




\begin{tabular}{|c|c|c|c|}
\hline \multicolumn{4}{|c|}{ Professional Participants } \\
\hline Name & Affiliation & Title & Role in Study \\
\hline $\begin{array}{l}\text { Alberto Matias } \\
\text { Gonzalez }\end{array}$ & $\begin{array}{l}\text { University of } \\
\text { Sancti Spiritus }\end{array}$ & Titular Professor & $\begin{array}{l}\text { Mentor, informant, } \\
\text { participant }\end{array}$ \\
\hline $\begin{array}{l}\text { Leticia Rueda } \\
\text { Castillo }\end{array}$ & ANAP & $\begin{array}{l}\text { Lead Coordinator } \\
\text { of the Farmer-to- } \\
\text { Farmer movement }\end{array}$ & Participant \\
\hline $\begin{array}{l}\text { Paula Quintana } \\
\text { Palenzuela }\end{array}$ & ACTAF & $\begin{array}{l}\text { Director, Sancti } \\
\text { Spiritus }\end{array}$ & Participant \\
\hline $\begin{array}{l}\text { Jorge Luis Ayala } \\
\text { Sifontes }\end{array}$ & CNSV & $\begin{array}{l}\text { Biocontrol } \\
\text { Specialist }\end{array}$ & $\begin{array}{l}\text { Primary Translator, } \\
\text { informant, } \\
\text { participant }\end{array}$ \\
\hline Sylvia Monzón & CNSV & $\begin{array}{l}\text { Biocontrol } \\
\text { Specialist (retired) }\end{array}$ & Participant \\
\hline $\begin{array}{l}\text { Armando } \\
\text { Marrero Pérez }\end{array}$ & CNSV & $\begin{array}{l}\text { Former Director, } \\
\text { Sancti Spiritus }\end{array}$ & Participant \\
\hline $\begin{array}{l}\text { Andrey Garcia } \\
\text { Diaz }\end{array}$ & CNSV & $\begin{array}{l}\text { Director, } \\
\text { Cabaiguán Field } \\
\text { Station }\end{array}$ & Participant \\
\hline Ruperto Gomez & CNSV & $\begin{array}{l}\text { Institutional } \\
\text { Communicator }\end{array}$ & $\begin{array}{l}\text { Informant and } \\
\text { participant }\end{array}$ \\
\hline
\end{tabular}




\section{Appendix B: Interview Guides}

\section{Semi-Structured Interview Guide: Producer Participants}

1. What is your age and education?

2. When did you begin work as a farmer? How long has this farm been in operation?

3. What led you to work as a farmer?

a. PROBE: Is there a history of farming in your family?

b. PROBE: Did the conditions of the "Special Period" affect your choice to begin farming?

4. What do you produce on this farm? What are your reasons for producing these crops?

5. Where did you learn the farming practices and techniques you use?

6. What types of traditional farming practices, if any, do you use?

7. How have the practices and techniques you use changed over time? Can you give me an example?

8. How do you manage soil and water conditions? Can you give me some examples?

9. How do you manage your crops? Can you give me some examples (crop rotation, pests, diseases, fertilization)?

10. What are the benefits of using these management strategies (soil, water, crops, pests, diseases and fertilization)?

11. Do you work with scientists or people from ANAP or ACTAF? How so?

a. PROBE: Have they taught you practices? Which ones? Why did they teach you these practices?

b. PROBE: Have you taught them any practices?

12. What types of agricultural extension activities do you consider helpful/not helpful?

13. What does food security mean to you?

a. PROBE: Do you consider your work as a farmer to contribute to the food security of Cuba?

b. PROBE: Is it important to contribute to the food security of Cuba?

14. Do you know the Antonio Nunez Jimenez Foundation for Nature and Humanity? It is an environmental organization and their mission is to work towards "a Cuban society with a developed environmental conscience that will recognize nature as part of its identity." What does this mean to you?

a. PROBE: Do you think about yourself as part of nature?

b. PROBE: In your opinion, does the idea of humans being a part of nature impact your farming, or farming in Cuba? How so?

15. In your opinion, how did the "Special Period" affect farming in Cuba? How did it affect your farm? 


\section{Semi-Structured Interview Guide: Professional Participants (Cuban Agricultural Scientists and Extension Workers)}

1. What is your age and education?

2. What is your history or background working with farmers in Cuba?

3. How has farming in Cuba changed over the years (from before the revolution until now)?

4. How would you describe the current situation of agriculture in Cuba?

a. PROBE: Are farmers more or less inclined to use chemicals?

b. PROBE: What type of agriculture is most commonly practiced?

5. In your experience, how do farmers generally respond to agricultural extension?

6. What are the biggest challenges to the adoption of agroecological methods?

7. What does food security for Cuba mean to you?

8. Do you know the saying "Necessity is the Mother of Creation"? What does it mean to you?

9. Do you know the Antonio Nunez Jimenez Foundation for Nature and Humanity? It is an environmental organization and their mission is to work towards "a Cuban society with a developed environmental conscience that will recognize nature as part of its identity." What does this mean to you?

a. PROBE: How do you understand the relationship between human beings and nature?

b. PROBE: How does this relationship impact farming in Cuba?

10. In your opinion, when did the shift to more ecological and biological methods of agriculture begin in Cuba?

11. In your opinion, how did the "Special Period" affect farming in Cuba? What does the phrase "Special Period survival" mean to you?

12. How might the improvement of the economy affect the adoption/expansion of agroecology in Cuba?

13. How have your own ideas about agriculture and agro-ecology in Cuba changed over the years?

a. PROBE: How have your personal sentiments regarding agriculture changed?

b. PROBE: How has your profession influenced your ideas about agriculture? 


\title{
Appendix C: Letters of Information and Consent Forms
}

\section{Carleton}

\author{
Canada's Capital University
}

\section{Letter of Information and Consent Form: Producer Participants}

\section{Background}

Lina Johnston is a Master's Anthropology student from Carleton University in Ottawa, Canada. In order to complete her Master's she must conduct a research project of her own design. She is conducting research into the relationship between agricultural practice and Cuban farmer identity. In October 2010, she took part in a one-week field visit to the University of Sancti Spiritus to determine the goals of this research project. During this visit, she became particularly interested in how agroecology (sustainable agriculture) is defined and practiced in Cuba. This letter is intended to inform you, the prospective interviewee, about this project and to request your assistance in this research.

\section{Purpose of the research}

As a result of the conditions of the "Special Period" brought on by the 1989 dissolution of the Soviet Union, the Cuban agricultural system has undergone a large-scale reformation from agrochemical to agroecological farming practices. However, the use of agrochemicals among Cuban farmers is still common. Therefore, the purposes of this research are to: 1) conduct a casestudy of two farm communities in Sancti Spiritus, Cuba; 2) explore the socio-cultural factors that lead Cuban farmers to use agrochemical, or agroecological farming practices.

\section{Invitation to participate}

This research will benefit from your experience and expertise, and Ms. Johnston would like to invite you to participate in an interview. The interview will take place in person (at a location of your choosing). The interview should last 45- 60 minutes. If you are a native Spanish speaker, a translator will be present. Please note that the translator will sign a Translator Confidentiality Agreement. You may be contacted by e-mail or in person, should a follow-up question or point of clarification arise. When this research project is completed, you will be notified as to where the research results can be found.

\section{Risk, confidentiality and interview information}

There may be some risk to you as the Cuban government may disagree with your opinions, observations and comments. If, for any reason, you become uncomfortable during or after the interview, you will retain the right to withdraw your responses, and any information obtained will be destroyed. You will retain this right until Ms. Johnston begins her data analysis: July 14, 2011. After this date, you may no longer withdraw. Alternately, if you have said something you 
would like removed from the record, your wishes will be respected and observed. Interview transcripts (raw data) will be seen only by Ms. Johnston. You're identity is known to the faculty at the University of Sancti Spiritus, the Cuban Ministry of Agriculture (MINAGRI), Sanidad Vegetal, and the Asociación Nacional de Agricultores Pequeños (ANAP). You will not be identified by name or by title in any reports written using the information that you provide, and your responses will not be attributed to you. Ms. Johnston will not disclose participants in the study to one another. Audio recording and notes of your interview will be securely stored in a locked location, and only she will have access to them. All primary data obtained will be destroyed within five years of this research project.

If you have any questions or concerns, please do not hesitate to contact me:

Lina Johnston, MA

Faculty of Arts and Social Sciences

Department of Sociology and Anthropology

Carleton University

1125 Colonel By Drive

Ottawa, ON, Canada K1S 5B6

ljohnsto@connect.carleton.ca

Tel.: (613) 832- 4108

This project has received ethics clearance by the Carleton University Research Ethics Board. Should you have any concerns or questions about this research or our conduct, please do not hesitate to contact:

Antonio Gualtieri, Chair

Research Ethics Committee

Carleton University, 1125 Colonel By Drive

Ottawa, ON, Canada, K1S 5B6

ethics@carleton.ca

Tel: 613-520-2517

Thank you for your consideration.

Lina Johnston 
would like removed from the record, your wishes will be respected and observed. Interview transcripts (raw data) will be seen only by Ms. Johnston. You're identity is known to the faculty at the University of Sancti Spiritus, the Cuban Ministry of Agriculture (MINAGRI), Sanidad Vegetal, and the Asociación Nacional de Agricultores Pequeños (ANAP). You will not be identified by name or by title in any reports written using the information that you provide, and your responses will not be attributed to you. Ms. Johnston will not disclose participants in the study to one another. Audio recording and notes of your interview will be securely stored in a locked location, and only she will have access to them. All primary data obtained will be destroyed within five years of this research project.

If you have any questions or concerns, please do not hesitate to contact me:

Lina Johnston, MA

Faculty of Arts and Social Sciences

Department of Sociology and Anthropology

Carleton University

1125 Colonel By Drive

Ottawa, ON, Canada K1S 5B6

ljohnsto@.connect.carleton.ca

Tel.:

This project has received ethics clearance by the Carleton University Research Ethics Board. Should you have any concerns or questions about this research or our conduct, please do not hesitate to contact:

Antonio Gualtieri, Chair

Research Ethics Committee

Carleton University, 1125 Colonel By Drive

Ottawa, ON, Canada, K1S 5B6

ethics@carleton.ca

Tel: 613-520-2517

Thank you for your consideration.

Lina Johnston 


\section{Participant consent to interview}

I, have read the above letter and understand that I am participating in a research project and I voluntarily agree to participate.

$\square$ I consent to an audio recording of the interview.

$\square$ I do not consent to an audio recording of the interview

Respondent's signature

Date

Researcher's signature

Date 


\section{Carleton \\ U N I V E R S I T Y}

Canada's Capital University

\section{Letter of Information and Consent Form: Professional Participants (Cuban Agricultural Scientists and Extension Workers)}

\section{Background}

Lina Johnston is a Master's Anthropology student from Carleton University in Ottawa, Canada. In order to complete her Master's she must conduct a research project of her own design. She is conducting research into the relationship between agricultural practice and Cuban farmer identity. In October 2010, she took part in a one-week field visit to the University of Sancti Spiritus to determine the goals of this research project. During this visit, she became particularly interested in how agroecology (sustainable agriculture) is defined and practiced in Cuba. This letter is intended to inform you, the prospective interviewee, about this project and to request your assistance in this research.

\section{Purpose of the research}

As a result of the conditions of the "Special Period" brought on by the 1989 dissolution of the Soviet Union, the Cuban agricultural system has undergone a large-scale reformation from agrochemical to agroecological farming practices. However, the use of agrochemicals among Cuban farmers is still common. Therefore, the purposes of this research are to: 1) conduct a casestudy of two farm communities in Sancti Spiritus, Cuba; 2) explore the socio-cultural factors that lead Cuban farmers to use agrochemical, or agroecological farming practices.

\section{Invitation to participate}

This research will benefit from your experience and expertise, and Ms. Johnston would like to invite you to participate in an interview. The interview will take place in person (at a location of your choosing). The interview should last 45- 60 minutes. If you are a native Spanish speaker, a translator will be present. Please note that the translator will sign a Translator Confidentiality Agreement. You may be contacted by e-mail or in person, should a follow-up question or point of clarification arise. When this research project is completed, you will be notified as to where the research results can be found.

\section{Risk, confidentiality and interview information}

There may be some risk to you as the Cuban government may disagree with your opinions, observations and comments. If, for any reason, you become uncomfortable during or after the interview, you will retain the right to withdraw your responses, and any information obtained will be destroyed. You will retain this right until Ms. Johnston begins her data analysis: July 14, 2011. After this date, you may no longer withdraw. Alternately, if you have said something you would like removed from the record, your wishes will be respected and observed. Interview 
transcripts (raw data) will be seen only by Ms. Johnston. You will be identified by name or by title in any reports written using the information that you provide, and your responses will be attributed to you. Ms. Johnston will not disclose participants in the study to one another. Audio recording and notes of your interview will be securely stored in a locked location, and only she will have access to them. All primary data obtained will be destroyed within five years of this research project.

If you have any questions or concerns, please do not hesitate to contact me:

Lina Johnston, MA

Faculty of Arts and Social Sciences

Department of Sociology and Anthropology

Carleton University

1125 Colonel By Drive

Ottawa, ON, Canada K1S 5B6

ljohnsto@,connect.carleton.ca

Tel.: (613)

This project has received ethics clearance by the Carleton University Research Ethics Board. Should you have any concerns or questions about this research or our conduct, please do not hesitate to contact:

Antonio Gualtieri, Chair

Research Ethics Committee

Carleton University, 1125 Colonel By Drive

Ottawa, ON, Canada, K1S 5B6

ethics@carleton.ca

Tel: 613-520-2517

Thank you for your consideration.

Lina Johnston 


\section{Participant consent to interview}

I, have read the above letter and understand that I am participating in a research project and I voluntarily agree to participate.

$\checkmark$ I consent to an audio recording of the interview.

$\square$ I do not consent to an audio recording of the interview

Respondent's signature

Date

Researcher's signature

Date 


\section{Appendix D: Translator Confidentiality Agreement}

Translator Confidentiality Agreement

\section{Carleton \\ U NIVERSITY}

$\mathrm{I}$, , as translator, will be permitted to have access to interview participant information in order to translate, from Spanish to English or English to Spanish, data related to the research project of Lina Johnston (Department of Sociology and Anthropology, Carleton University).

I agree to keep all information that I learn about the participant confidential. I understand that I may not discuss or disclose any information related to this interview outside the interview setting. I further understand that I may learn personal information about a participant that is private. I understand that it is my duty and responsibility to preserve and protect this privacy and confidentiality. I understand that this duty will extend after I am no longer working in the interview setting.

By placing my signature below, I hereby indicate that I understand and agree to maintain the privacy of the interview responses and confidentiality of the participant's identity. 